\title{
Reprogramming of plants during systemic acquired resistance
}

\author{
Katrin Gruner ${ }^{1}$, Thomas Griebel ${ }^{2}$, Hana Návarová ${ }^{1}$, Elham Attaran ${ }^{3}$ and Jürgen Zeier ${ }^{1 *}$ \\ 'Department of Biology, Heinrich Heine University, Düsseldorf, Germany \\ ${ }^{2}$ Department of Plant-Microbe Interactions, Max Planck Institute for Plant Breeding Research, Cologne, Germany \\ ${ }^{3}$ Department of Plant Biology, Michigan State University, East Lansing, MI, USA
}

\section{Edited by:}

Corné M. J. Pieterse, Utrecht

University, Netherlands

\section{Reviewed by:}

Peer Schenk, The University of

Queensland, Australia

Jyoti Shah, University of North

Texas, USA

Jean-Pierre Metraux, Université de

Fribourg, Switzerland

\section{*Correspondence:}

Jürgen Zeier, Department of

Biology, Heinrich Heine University,

Universitätsstraße 1, 40225

Düsseldorf, Germany

e-mail: Juergen.Zeier@

uni-duesseldorf.de
Genome-wide microarray analyses revealed that during biological activation of systemic acquired resistance (SAR) in Arabidopsis, the transcript levels of several hundred plant genes were consistently up- $\left(\mathrm{SAR}^{+}\right.$genes) or down-regulated (SAR ${ }^{-}$genes) in systemic, non-inoculated leaf tissue. This transcriptional reprogramming fully depended on the SAR regulator FLAVIN-DEPENDENT MONOOXYGENASE1 (FMO1). Functional gene categorization showed that genes associated with salicylic acid (SA)-associated defenses, signal transduction, transport, and the secretory machinery are overrepresented in the group of $\mathrm{SAR}^{+}$genes, and that the group of $\mathrm{SAR}^{-}$genes is enriched in genes activated via the jasmonate (JA)/ethylene (ET)-defense pathway, as well as in genes associated with cell wall remodeling and biosynthesis of constitutively produced secondary metabolites. This suggests that SAR-induced plants reallocate part of their physiological activity from vegetative growth towards SA-related defense activation. Alignment of the SAR expression data with other microarray information allowed us to define three clusters of $\mathrm{SAR}^{+}$genes. Cluster I consists of genes tightly regulated by SA. Cluster II genes can be expressed independently of $\mathrm{SA}$, and this group is moderately enriched in $\mathrm{H}_{2} \mathrm{O}_{2}$ - and abscisic acid (ABA)-responsive genes. The expression of the cluster III SAR ${ }^{+}$genes is partly SA-dependent. We propose that SA-independent signaling events in early stages of SAR activation enable the biosynthesis of SA and thus initiate SA-dependent SAR signaling. Both SA-independent and SA-dependent events tightly co-operate to realize SAR. SAR ${ }^{+}$genes function in the establishment of diverse resistance layers, in the direct execution of resistance against different (hemi-)biotrophic pathogen types, in suppression of the JA- and ABA-signaling pathways, in redox homeostasis, and in the containment of defense response activation. Our data further indicated that SAR-associated defense priming can be realized by partial pre-activation of particular defense pathways.

Keywords: systemic acquired resistance, transcriptional profiling, salicylic acid, gene classification, gene regulation, defense priming

\section{INTRODUCTION}

Plants are equipped with a multi-layered immune system that employs constitutive and inducible defense strategies to antagonize colonization by pathogenic microbes (Spoel and Dong, 2012). In pathogen-inoculated plant tissue, conserved microbial structures (pathogen-associated molecular patterns, PAMPs) elicit PAMP-triggered immunity (PTI), a basal resistance response that contains the extent of infection by compatible pathogen isolates. Following recognition of race-specific pathogen effectors by plant immune receptors ("resistance proteins"), plants are able to activate effector-triggered immunity (ETI) that usually results in a hypersensitive response (HR) at inoculation sites and provides effective local resistance to pathogens with a biotrophic or hemibiotrophic lifestyle (Jones and Dangl, 2006). Although ETI is associated with stronger local responses than PTI, the signaling networks underlying both resistance forms partially overlap (Tsuda et al., 2009).
A localized microbial infection of a single or a few leaves can also immunize the rest of the foliage to subsequent infection, a phenomenon known as systemic acquired resistance (SAR) (Fu and Dong, 2013; Shah and Zeier, 2013). Once activated, SAR provides enhanced resistance to a broad range of (hemi) biotrophic fungal, bacterial, and viral pathogens (Sticher et al., 1997). The SAR response is initiated by microbes eliciting PTI or ETI at inoculation sites, and can also be triggered by localized leaf treatment with purified PAMPs. The mechanistic principles leading to SAR induction by different types of bacterial pathogens and the resulting systemic immunization patterns are highly overlapping (Mishina and Zeier, 2007; Jing et al., 2011). For instance, compatible, PTI-inducing Pseudomonas syringae pv. maculicola ES4326 (Psm) and ETI-inducing Psm avrRpm1 elicit highly similar systemic responses in Arabidopsis thaliana (Arabidopsis) plants, including systemic accumulation of the SAR immune signals pipecolic acid (Pip) and salicylic acid (SA), and 
enhanced systemic expression of a variety of classical SAR marker genes such as PATHOGENESIS-RELATED GENE 1 (PR1), PR2, and PR5 (Mishina and Zeier, 2006; Návarová et al., 2012).

Effective long-distance communication between inoculated $\left(1^{\circ}\right)$ leaves and distant $\left(2^{\circ}\right.$, "systemic") leaves is required for the activation of SAR. Several plant-derived substances have been proposed to participate in SAR long-distance signaling (Dempsey and Klessig, 2012; Shah and Zeier, 2013). These involve the putative lipid transfer protein DEFECTIVE IN INDUCED RESISTANCE1 (DIR1), the methyl ester of SA (MeSA), glycerol3-phosphate (G3P), the diterpenoid dehydroabietinal, the dicarboxylic acid azelaic acid, and the Lys catabolite Pip (Maldonado et al., 2002; Park et al., 2007; Jung et al., 2009; Chanda et al., 2011; Chaturvedi et al., 2012; Návarová et al., 2012). The importance of several of these candidate signals for SAR induction in plants appears to depend on external parameters such as the light environment (Attaran et al., 2009; Liu et al., 2011; Návarová et al., 2012).

At the onset of SAR, the long-distance information released from $1^{\circ}$ leaves is supposed to be perceived in $2^{\circ}$ leaf tissue (Shah and Zeier, 2013), and a feedback amplification mechanism in $2^{\circ}$ leaves that involves Pip and SA then ensures the activation of SAR (Návarová et al., 2012). The Lys aminotransferase AGD2-LIKE DEFENSE RESPONSE PROTEIN1 (ALD1), whose expression is intensified in 1 and $2^{\circ}$ leaves during SAR, is required for SAR activation (Song et al., 2004a,b). ALD1 generates the non-protein amino acid Pip, which has recently been identified as a critical metabolic SAR signal (Návarová et al., 2012). Pip-mediated resistance requires FLAVIN-DEPENDENT MONOOXYGENASE1 (FMO1), another indispensable SAR module (Mishina and Zeier, 2006; Návarová et al., 2012). Pip enhances both its own biosynthesis and downstream signaling in SAR via intensification of ALD1 and FMO1 expression, and systemic accumulation of the amino acid is required for the de novo synthesis of SA in $2^{\circ}$ leaf tissue (Návarová et al., 2012). SA is a second critical SAR metabolite that is produced in plants from chorismate by ISOCHORISMATE SYNTHASE1 (ICS1) (Wildermuth et al., 2001; Métraux, 2002). SA induces SAR-related gene expression via the downstream regulator NON-EXPRESSER OF PR GENES1 (NPR1), a transcriptional co-activator and bona fide SA receptor (Wu et al., 2012; Fu and Dong, 2013). SAR-induced plants therefore exhibit increased expression of a number of $P R$ genes which is presumed to directly contribute to their state of increased disease resistance (Sticher et al., 1997). Additionally, SAR confers defense priming, which enables plants to more effectively respond to future pathogen encounter (Jung et al., 2009; Návarová et al., 2012).

The interaction between Arabidopsis and P. syringae represents a useful model system to elucidate the molecular principles underlying inducible plant immunity (Katagiri et al., 2002). Large scale transcriptional profiling in Arabidopsis has been used to better understand PTI- and ETI-associated defense networks that are activated at sites of bacterial inoculation, and the mode of action of bacterial effectors to promote disease (Thilmony et al., 2006; Truman et al., 2006; Wang et al., 2008; Tsuda et al., 2009). Moreover, genome-wide microarray analyses have been employed to characterize Arabidopsis transcriptional responses induced by the synthetic resistance activator
S-methyl-1,2,3-benzothiadiazole-7-carbothioate (BTH), which is often considered as a functional SA analogue (Wang et al., 2006). A DNA microarray representing about $25-30 \%$ of the Arabidopsis genes has also been used to monitor and analyse gene expression changes under different SAR-inducing conditions (Maleck et al., 2000).

In the current study, we aimed to characterize biologicallyinduced SAR in Arabidopsis at the whole genome level, classify SAR-regulated genes according to their function and regulation of expression, derive molecular and physiological characteristics of the SAR-induced state, and further clarify the role of FMO1 in SAR. We therefore analysed the transcriptional changes that occur in upper $2^{\circ}$ leaf tissue upon SAR induction with Psm bacteria in lower $1^{\circ}$ leaves by use of ATH1 microarray chip analyses in the Arabidopsis wild-type and fmo1 mutant plants. These analyses revealed that SAR is associated with massive transcriptional reprogramming in systemic tissue that virtually fully depends on FMO1. Alignment of the SAR expression data with publicly available microarray information from defense-, stress-, and hormone-related experiments allowed us to obtain information about the regulation of genes that are up- and down-regulated during SAR. For instance, within the group of genes up-regulated during SAR, subgroups consisting of SA-independent, SA-dependent, and partially SA-dependent genes could be discriminated. Moreover, our evaluation indicated that overlapping and contrasting regulatory principles exist for the induction of local resistance responses and SAR. Further, functional categorization of SARrelated genes suggested that, upon SAR induction, plants redirect some of their resources from vegetative growth towards defense.

\section{MATERIALS AND METHODS PLANT MATERIAL AND GROWTH CONDITIONS}

Arabidopsis thaliana (L.) Heynh. ecotype Col-0 and fmo1 mutant plants (T-DNA insertion line SALK_026163; Mishina and Zeier, 2006) were grown in individual pots on an autoclaved mixture of soil (Klasmann, Beetpflanzensubstrat Typ R.H.P.16), vermiculite and sand (10:0.5:0.5) in a controlled environmental chamber (J66LQ4, Percival, Boone, IA) within $9 \mathrm{~h}$ day (9 AM to $6 \mathrm{PM}$; photon flux density $70 \mu \mathrm{mol} \mathrm{m} \mathrm{m}^{-2} \mathrm{~s}^{-1}$ ) and $15 \mathrm{~h}$ night periods in a relative humidity of $70 \%$. Growth temperatures during the day and night period were set to $21^{\circ} \mathrm{C}$ and $18^{\circ} \mathrm{C}$, respectively. SAR experiments were performed with 5-6 week-old plants exhibiting a uniform appearance.

\section{SAR EXPERIMENTS}

Overnight cultures of Pseudomonas syringae pv. maculicola ES4326 (Psm) were cultivated as described (Mishina and Zeier, 2006). For SAR induction, plants were infiltrated between 10 AM and $11 \mathrm{AM}$ into three lower $\left(1^{\circ}\right)$ leaves (typically leaf 7-9) with a suspension of Psm in $10 \mathrm{mM} \mathrm{MgCl}_{2}$ [optical density at $600 \mathrm{~nm}$ $\left.\left(\mathrm{OD}_{600}\right)=0.005\right]$. Infiltration with $10 \mathrm{mM} \mathrm{MgCl} 2$ served as the mock-control treatment. Upper $\left(2^{\circ}\right)$ leaves (typically leaf 10-12) were harvested and shock-frozen in liquid nitrogen two days after the treatment of $1^{\circ}$ leaves. Together, three biologically independent SAR experiments were performed for microarray analyses 
(see below), and two further biological replicates were performed for qPCR-based expression analyses of selected genes (Table 2).

\section{RNA ISOLATION}

Total RNA was isolated from frozen leaves using QIAzol ${ }^{\circledR}$ Lysis Reagent (Qiagen, http://www.qiagen.com/) following the manufacturer's instructions. For each sample, two leaves from different plants that received the same treatment were used.

\section{QUANTITATIVE REAL-TIME PCR ANALYSIS}

RNA samples were reverse-transcribed with the Omniscript RT Kit (Qiagen) using $1 \mu \mathrm{g}$ of total RNA. $2.5 \mu \mathrm{l}$ of cDNA and $5 \mu \mathrm{l}$ of SensiFAST ${ }^{\text {тм }}$ SYBR No-ROX Kit (Bioline) were used in PCR reactions of $10 \mu \mathrm{l}$ total reaction volume containing $0.75 \mu \mathrm{M}$ gene-specific primers. The At4g26410 gene which is nonresponsive to $P$. syringae-inoculation was used as a reference gene (Czechowski et al., 2005). The following primers were used to obtain the expression data for SAR experiments 4 and 5 (Table 2): PR1-FORWARD: 5'-GTGCTCTTGTTCTTCCCTCG-3', PR1REVERSE: 5'-GCCTGGTTGTGAACCCTTAG-3', PR2-FW: 5'-TCAAGGAAGGTTCAGGGATG-3', PR2-RV: 5'-GAGATTC ACGAGCAAGGGAG-3', PR5-FW: 5'-ATCGGGAGATTGCA AATACG-3', PR5-RV: 5'-ATGACCTTAAGCATGTCGGG-3', AGP5-FW: 5'-CTACTGAATCTCCACCAGCTC-3', AGP5-RV: 5'-GAGGGAGACTCTGCTAACTG-3', CALM3-FW: 5'-GAC TGATGATAAATCGTTGGAG-3', CALM3-RV: $5^{\prime}$-CCCAACA AACTAAGCATCCT-3', LTPa-FW: 5'-GGTTCTACTTCTGACT CTCC-3', LTPa-RV : $5^{\prime}$-GTCCGTCTCCTTCTCCT-3', PBS3-FW: $5^{\prime}$-TGCCTGCTCGAGTCGCAACC-3', PBS3-RV: $5^{\prime}$-TGGACTAA GCCACAGAGCAAATGGC-3', UGT76B1-FW: 5'-CTTTACA AGAGACTAAGGCAG-3', UGT76B1-RV: 5'-CACACCTATCT GTAACTTATCCC-3', 2OGD1-FW: 5'-ACCAAATGCAGGTCA TAAGC-3', 2OGD1-RV: 5'-TGAAGGGAAATAGAAAGTCGG3', NIMIN-1-FW: 5'-AGTAAGAGAAGACGAAGAAGAG-3', NIMIN-1-RV: 5'-TCCGCCGTTAGATTTCCT-3', At4g26410$F W: \quad 5^{\prime}$-GAGCTGAAGTGGCTTCCATGAC-3', At4g26410-RV: $5^{\prime}$-GGTCCGACATACCCATGACC-3'. The qPCR reaction was performed in triplicate in a Rotor-Gene $\mathrm{Q}$ apparatus (Qiagen) using the cycling program: $95^{\circ} \mathrm{C}$ for $2 \mathrm{~min}$, followed by 40 cycles at $95^{\circ} \mathrm{C}$ for $7 \mathrm{~s}, 60^{\circ} \mathrm{C}$ for $25 \mathrm{~s}$, and finally $72^{\circ} \mathrm{C}$ for $3 \mathrm{~min}$. The data was analyzed using the Rotor-Gene Q 2.0.2 software, setting the threshold of the normalized fluorescence to 0.1 , which corresponded to the exponential phase of the fluorescence signal. The resulting $\mathrm{C}_{\mathrm{T}}$ and $\mathrm{E}$ values were used to calculate the relative mRNA abundance according to the $\Delta \Delta \mathrm{C}_{\mathrm{T}}$ method (Livak and Schmittgen, 2001). The values were normalized to those of the reference gene and expressed relative to the mock-control sample.

\section{MICROARRAY ANALYSIS AND DATA EVALUATION}

For each SAR microarray experiment, RNA samples from at least 7 replicates for a particular condition (Col-0/mock, Col0/SAR, fmol/mock, fmol/SAR) were mixed. The pooled RNA samples were quality-checked and expression profiling performed with the GeneChip ${ }^{\circledR}$ Arabidopsis ATH1 Genome Array using the $3^{\prime}$ IVT express kit (Affymetrix) under accreditation conditions (DNAVision, Charleroi, Belgium). The quality of the used GeneChips was assessed and all the samples were hybridized, processed, and scanned in parallel, ensuring that samples could be directly compared to each other. Moreover, the raw microarray data was normalized using the RMA algorithm (Irizarry et al., 2003a,b).

Together, three biologically independent SAR microarray experiments were performed. Statistical analyses of the normalized expression values of the three biological replicates were performed using a two-sided Student's $t$-test. The large scale evaluation of the microarray data was performed using Microsoft Excel ${ }^{\circledR}$ data sheets. Ratios of normalized expression values for Psm- and mock samples were calculated ([P/M $\left.]_{\mathrm{SAR}}\right)$, and genes were arranged and grouped according to the size of their averaged $[P / M]_{\text {SAR }}$ values with the Excel ${ }^{\circledR}$ data sort function. Similarly, mean gene expression values gathered from other publicly available microarray experiments were determined for each gene, and stimulus-to-mock ratios $\left([S / \mathrm{M}]_{\text {stimulus }}\right)$ and ratios of local expression values in Col-0 and mutant leaves following Psm inoculation $\left([\mathrm{Col} / \text { mutant }]_{\mathrm{Psm}}\right)$ were calculated thereof (Table 6). The $[P / \mathrm{M}]_{\text {SAR }}$ ratios for each gene were aligned with the corresponding $[\mathrm{S} / \mathrm{M}]_{\text {stimulus }}$ and $[\mathrm{Col} / \text { mutant }]_{\text {Psm }}$ ratios using the "merge" function of FIRe, an Excel ${ }^{\circledR}$ macro designed for rapid microarray data analysis (Garcion et al., 2006). The detailed selection criteria for the categorization of genes are described in the main text. The Arabidopsis Information Resource (TAIR) functional categorization tool was used to classify the genes according to Gene Ontology (GO) descriptions (http://www.arabidopsis.org/tools/ bulk/go/index.jsp). The SAR microarray data were deposited in the NASCArrays database (NASCARRAYS-703).

\section{DETERMINATION OF CAMALEXIN, ABSCISIC ACID, AND JASMONIC ACID LEVELS}

For the time course analyses of the local and systemic levels of camalexin, JA, and ABA (Figure 8), three $1^{\circ}$ leaves of Arabidopsis Col-0 plants were treated with Psm $\left(\mathrm{OD}_{600}=0.005\right)$ or $10 \mathrm{mM}$ $\mathrm{MgCl}_{2}$. At the indicated times after treatment, the treated $\left(1^{\circ}\right)$ leaves and three upper, non-treated $\left(2^{\circ}\right)$ leaves were separately harvested and frozen in liquid nitrogen. Individual samples consisted of 6 leaves from two plants. The determination of the leaf metabolite levels was performed by vapor-phase extraction and subsequent GC/MS analysis as described by Návarová et al. (2012). For quantification, metabolite peaks originating from selected ion chromatograms were integrated: camalexin $(\mathrm{m} / \mathrm{z}$ 200), ABA (m/z 190), and JA (m/z 224). The area of a substance peak was related to the peak area of dihydrojasmonic acid $(\mathrm{m} / \mathrm{z} 156)$ or indole-3-propionic acid $(\mathrm{m} / \mathrm{z} 130)$ for internal standardization. Experimentally determined correction factors were considered.

\section{RESULTS AND DISCUSSION FUNCTIONAL CHARACTERIZATION OF THE SAR STATE}

The bacterial phytopathogen Pseudomonas syringae pv. maculicola ES4326 (Psm) triggers a classical and robust SAR response in vegetatively growing Arabidopsis thaliana plants (Mishina and Zeier, 2006; Jing et al., 2011). SAR induced in Arabidopsis by compatible Psm or HR-inducing Psm avrRpm1 develops between day 1 and day 2 in the whole foliage after a localized leaf inoculation has occurred, and the SAR response is fully established 
2 days post inoculation (dpi) (Mishina et al., 2008). We aimed to broaden our understanding of the nature of the SAR state by gathering and analyzing the transcriptional changes that occur upon SAR establishment on the whole Arabidopsis genome level. Therefore, we inoculated lower $\left(1^{\circ}\right)$ rosette leaves of 5 week-old Arabidopsis vegetatively growing Col-0 plants with a suspension of Psm $\left(\mathrm{OD}_{600}=0.005\right)$ and harvested upper, non-treated $\left(2^{\circ}\right)$ leaves two days after inoculation for RNA extraction. A mock-infiltration of $1^{\circ}$ leaves with $10 \mathrm{mM} \mathrm{MgCl}_{2}$ served as a control treatment. Affymetrix expression analysis (GeneChip ${ }^{\circledR}$ Arabidopsis ATH1 Genome Array) was then used to compare the expression profiles in $2^{\circ}$ leaves of mock- and Psm-treated plants. Considering the above-mentioned kinetics of SAR induction in the Psm-Col-0 pathosystem, the selected time point at 2 dpi allowed us to characterize the transcriptional reprogramming events when SAR has just fully established, but potentially not the earliest transcriptional events at the very onset of the response. We also included the fmo1 mutant into the study which is fully compromised in SAR, systemic accumulation of SA, and systemic expression of characteristic SAR marker genes (Mishina and Zeier, 2006).

In sum, we performed three independent SAR experiments that were conducted in the same growth chamber under identical light, temperature and humidity settings at different time periods with distinct batches of plants and pathogens. Each of the independent SAR experiments yielded one pooled RNA sample for both the mock-control and the SAR-induced state that was used for microarray analysis. The pooled RNA samples were derived from at least seven biological replicates within each SAR experiment and every biological replicate consisted of two $2^{\circ}$ leaves from distinct plants. Thus, the gene expression samples resulting from an individual SAR experiment exhibited a high intrinsic statistical validity. The 12 pooled RNA samples for microarray analysis (3 Col-0/mock, 3 Col-0/SAR, 3 fmol/mock, 3 fmol/SAR) were quality-checked and expression profiling performed using the $3^{\prime}$ IVT express kit (Affymetrix) under accreditation conditions (DNAVision, Charleroi, Belgium). The raw ATH1 microarray data was normalized using the RMA algorithm and normalized expression values obtained (Irizarry et al., 2003a,b).

To define genes systemically up-regulated during the SAR state in Col-0 plants $\left(\mathrm{SAR}^{+}\right.$genes), we first calculated the ratios of the normalized expression values for the $\underline{P} s m$ - and mock-samples from individual SAR experiments for each gene $[P / M]_{S A R}$, determined the mean values for the 3 ratios from different experiments for each gene, and selected those genes that were up-regulated by a factor of at least 3 on average. We further applied a two-sided $t$-test between the normalized expression values of the Psm-and those of the mock-samples for each gene and excluded those genes from our list with a $P$-value $>0.05$. These two selection criteria yielded 305 genes out of the 22810 genes represented on the ATH1 GeneChip that were up-regulated by a factor of at least 3 in a statistically significant manner among the 3 individual SAR experiments (Table 1A). The number of genes up-regulated upon SAR induction on average by a factor of 5 and 10 amounted to 149 and 67, respectively. For the fmo1 mutant, not a single SAR ${ }^{+}$ gene existed based on these criteria (Table 1B), corroborating our previous findings that functional FMO1 is critical for the activation of systemic defense responses and SAR (Mishina and Zeier, 2006; Návarová et al., 2012). We also recognized that expression of several genes was consistently suppressed following SAR establishment in Col-0 plants (SAR ${ }^{-}$genes), although the overall degree of gene down-regulation was lower than the degree of up-regulation (Tables 1A,B). For instance, 17 and 276 genes were significantly down-regulated by a factor of at least $4\left([P / \mathrm{M}]_{\text {SAR }}<\right.$ $0.25)$ and $2\left([P / M]_{\text {SAR }}<0.5\right)$, respectively. Again, not a single $\mathrm{SAR}^{-}$gene was differently expressed in $2^{\circ}$ leaves of Psm-and mock-treated fmol plants when following these selection criteria (Tables 1A,B).

Table 1 | Number of genes up- (SAR ${ }^{+}$genes) and down-regulated (SAR ${ }^{-}$genes) upon Psm-induced SAR in Arabidopsis Col-0 and fmo1.

\begin{tabular}{|c|c|c|c|c|c|c|c|c|c|}
\hline \multirow[t]{2}{*}{ A } & \multicolumn{2}{|c|}{ SAR $^{+}$(up-regulated) } & \multirow{2}{*}{$\begin{array}{c}\text { Col-0 } \\
67\end{array}$} & \multirow{2}{*}{$\begin{array}{l}\text { fmo1 } \\
0\end{array}$} & \multirow[t]{2}{*}{ B } & \multicolumn{2}{|c|}{ SAR- $^{-}$(down-regulated) } & \multirow{2}{*}{$\begin{array}{c}\text { Col-0 } \\
0\end{array}$} & \multirow{2}{*}{$\begin{array}{l}\text { fmo1 } \\
0\end{array}$} \\
\hline & {$[P / M]_{S A R}$} & $>10$ & & & & {$[P / M]_{S A R}$} & $<0.1$ & & \\
\hline & & $>5$ & 149 & 0 & & & $<0.25$ & 17 & 0 \\
\hline \multirow[t]{2}{*}{ C } & \multicolumn{2}{|c|}{$\mathrm{SAR}^{+}$(up-regulated) } & Col-0 & fmo1 & D & \multicolumn{2}{|c|}{$\mathrm{SAR}^{-}$(down-regulated) } & Col-0 & fmo1 \\
\hline & {$[P / M]_{S A R}$} & $>3$ & 547 & 4 & & & $>0.5$ & 700 & 0 \\
\hline
\end{tabular}

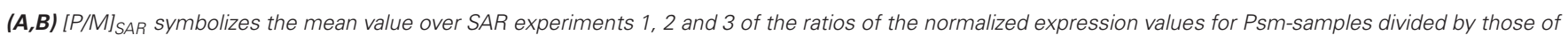

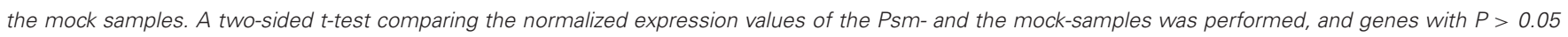

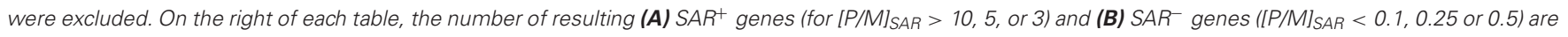

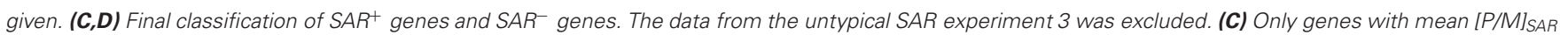

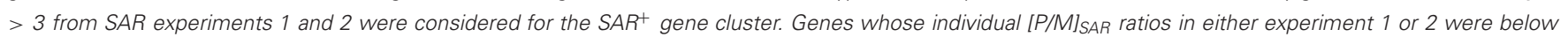

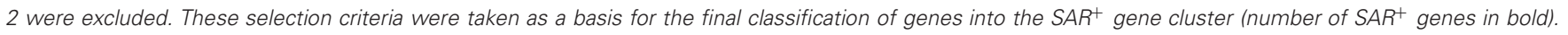

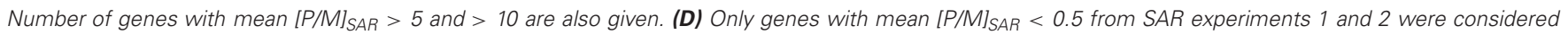

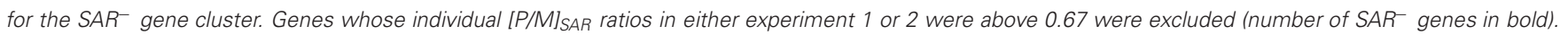
Number of genes with mean $[P / M]_{S A R}<0.25$ and $<0.1$ are also given. 
We next examined the $[P / M]_{S A R}$ expression ratios of individual genes from the distinct SAR experiments more closely. Remarkably, many genes that on average belonged to the most prominently SAR-induced genes were not up-regulated in a statistically significant manner $(P>0.05)$ or only barely exhibited significantly increased expression values over all 3 independent experiments. Table 2 lists 10 representative genes from this group. Among them are genes such as $P R 1, P R 2, P R 5$, and $P B S 3$, which belong, according to previous results from other groups and our own findings (Sticher et al., 1997; Maldonado et al., 2002; Mishina and Zeier, 2006; Lee et al., 2007), to the most characteristic $\mathrm{SAR}^{+}$genes. We recognized that many of these genes were highly induced in SAR experiments 1 and 2, but showed only a modest or low degree of up-regulation in experiment 3 (Table 2). For instance, $P R 1$ expression was induced by factors of 137,183 , and 7 in SAR experiments 1, 2, and 3, respectively. Thus, albeit markedly up-regulated in each of the individual SAR experiments, the high quantitative differences between expression values of experiment 3 compared to the two other experiments resulted in a $\mathrm{P}$ value larger than 0.05 for PR1. A similar trend was obvious for most of the other genes listed in Table 2. We consequently performed another two independent SAR experiments (experiments 4 and 5) and examined the expression characteristics of the 10 genes listed in Table 2 by quantitative real-time PCR analyses. Strikingly, in both newly conducted experiments, virtually all of the examined genes exhibited $[P / M]_{S A R}$ ratio quantitatively similar to experiments 1 and 2 . Furthermore, the $[P / \mathrm{M}]_{\mathrm{SAR}}$ values derived from experiments 4 and 5 for the genes PR1, AGP5, UGT76B1, LTPlike, $C A L M 3$, and $P B S 3$ were quantitatively much higher than the $[P / M]_{S A R}$ values obtained from experiment 3 . On the basis of this data and previous findings, we concluded that the bacterial inoculation in experiment 3 only provoked a modest SAR response on the transcriptional level that is not representative for the SAR response that is generally observed.

A subsequent systematic search for differently expressed genes in the control samples of experiments 1,2, and 3 identified about 50 genes that differed in their normalized expression values by a factor of 3 or more between experiment 3 and both other experiments. Interestingly, many of these genes represent central flavonoid pathway genes (Table 3). For instance, the normalized expression values of two main transcriptional regulators of anthocyanin biosynthesis, MYB90 and MYB75 (Borevitz et al., 2000), were about two and one order of magnitude, respectively, higher for the experiment 3-samples than for the samples from experiment 1 or 2. Similar quantitative expression patterns existed for DFR and ANS, encoding two key enzymes of the anthocyanidin biosynthesis pathway, dihydroflavonol reductase and anthocyanidin synthase, respectively, for the anthocyanin5-O-glucosyltransferase gene UGT75C1, for the anthocyanin coumaroyltransferase gene A3GlcCouT and for the glutathioneS-transferase gene GSTF12 that is involved in anthocyanin accumulation (Saito et al., 2013). Therefore, the biosynthesis of anthocyanins apparently was activated in the plants employed for experiment 3 to a markedly higher extent than in the plants from the other two experiments. Anthocyanin production in leaves is a characteristic response of plants to unfavorable environmental conditions such as drought, nitrogen deficiency or high

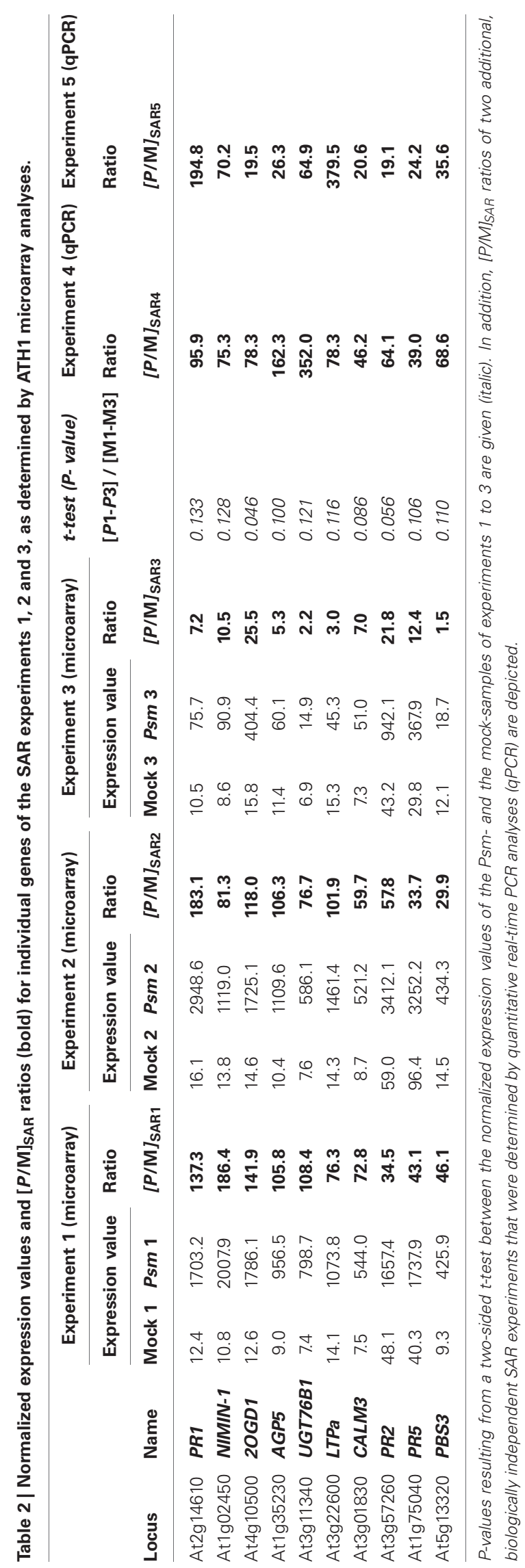


Table 3 | Several central anthocyanin biosynthesis genes exhibit high normalized expression values in plants of SAR experiment 3 compared with experiments 1 and 2 (M1-3: mock treatment experiment 1-3; P1-3: Psm treatment experiment 1-3).

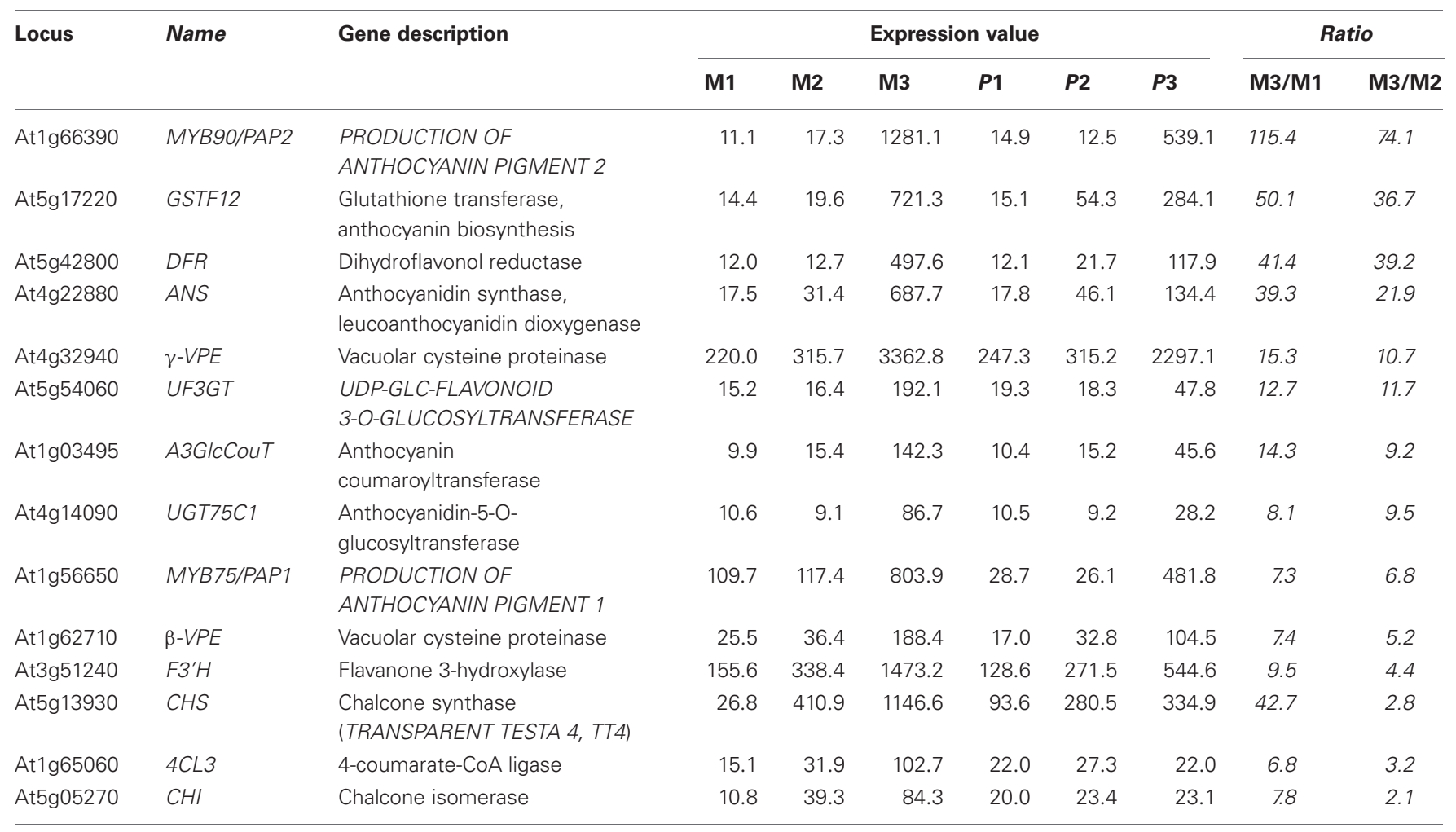

light stress (Misyura et al., 2013). Although the plants used in experiment 3 did not exhibit a macroscopically obvious stress phenotype, it is likely that they had suffered an unexpected stress exposure prior to or in the course of the SAR experiment that resulted in the activation of anthocyanin biosynthesis. Mutual influences between pathogen defense signaling and abiotic stress pathways or the anthocyanin biosynthesis pathway do exist (Fan et al., 2009; Saijo et al., 2009), and it is possible that the moderate SAR reaction observed in experiment 3 was a consequence of such cross-talk events.

Since the transcriptional data obtained from SAR experiment 3 markedly differed from those resulting from the other four experiments, we decided to exclude this data set from further analyses. We defined new selection criteria to classify the $\mathrm{SAR}^{+}$genes and only considered genes whose mean $[P / M]_{\text {SAR }}$ ratios from experiments 1 and 2 were larger than 3 , and whose individual $[P / M]_{\text {SAR }}$ ratios in either experiment was at least 2 . We thus ensured that a marked up-regulation of the selected $\mathrm{SAR}^{+}$genes had taken place in each of the experiments 1 and 2 . When following this procedure, all the characteristically SAR up-regulated genes listed in Table 2 fell into the category "SAR ${ }^{+}$genes" which altogether consisted of 547 genes for the Col-0 wild-type (Table 1C). Thereof, 295 and $145 \mathrm{SAR}^{+}$genes showed average $[P / M]_{\text {SAR }}$ ratios larger than 5 and 10, respectively (Table 1C). To classify genes downregulated during SAR, we selected genes with average $[P / M]_{\text {SAR }}$ ratios lower than 0.5 , whereby genes with rations higher than 0.67 in either experiment 1 or 2 were excluded. This procedure yielded a group of $700 \mathrm{SAR}^{-}$genes, from which 50 genes had average
$[P / \mathrm{M}]_{\text {SAR }}$ ratios lower than 0.25 and 2 genes exhibited average $[P / M]_{\text {SAR }}$ ratios lower than 0.1 (Table 1D). The new selection criteria pinpointed only 4 genes systemically up-regulated in fmo1 by a factor of at least 3 after Psm-infection. Moreover, not a single down-regulated gene was assigned for fmo1 (Tables 1C,D), again highlighting that fmo1 is virtually non-responsive to pathogen stimuli at the systemic plant level.

As a first step to functionally characterize the two clusters of $\mathrm{SAR}^{+}$and $\mathrm{SAR}^{-}$genes, we used the The Arabidopsis Information Resource (TAIR) functional categorization tool to classify the genes according to Gene Ontology (GO) descriptions which discriminates the three main classes "cellular component", "biological process" and "molecular function" (http://www.arabidopsis. org/tools/bulk/go/index.jsp). We thereby compared the $\mathrm{SAR}^{+}$ (547) and the $\mathrm{SAR}^{-}$(700) gene cluster with all the genes represented on the ATH1 Genechip (22810) (Tables 1C,D). In the class "cellular component", the functional categories "Golgi", "endoplasmatic reticulum (ER)", and "plasma membrane" were strongly overrepresented in the group of SAR ${ }^{+}$genes. Moreover, the categories "cell wall", "extracellular", and "cytosol" were moderately overrepresented among the $\mathrm{SAR}^{+}$genes, whereas the categories "plastid", "nucleus", and "ribosome" were underrepresented (Figure 1A). For the group of SAR ${ }^{-}$genes, it became apparent that "chloroplast", "plastid", "cell wall", and "extracellular" were highly represented categories (Figure 1A). These tendencies might indicate that cellular processes associated with the secretory apparatus and extracellular defenses are activated during SAR, and that certain activities occurring in chloroplasts and 


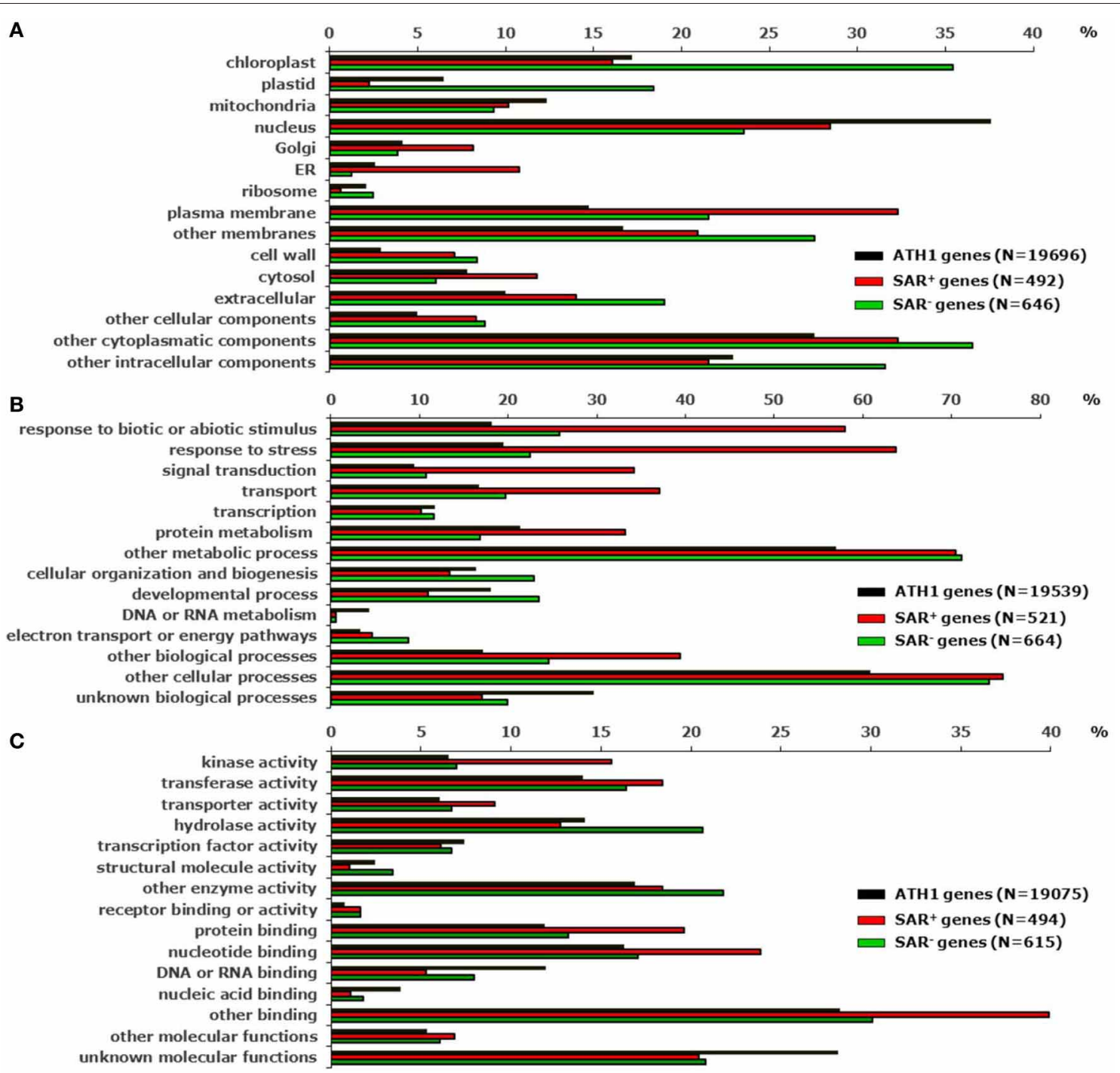

FIGURE 1 | Functional categorization of $\mathrm{SAR}^{+}$and $\mathrm{SAR}^{-}$genes according to Gene Ontology (GO) descriptions

(http://www.arabidopsis.org/tools/bulk/go/index.jsp). The 547 genes up-regulated during SAR by $[P / M]_{S A R}>3\left(S A R^{+}\right.$genes) (Table 1C), the 700 genes down-regulated during SAR by $\left[P / M_{S A R}<0.5\right.$ (SAR ${ }^{-}$genes)

(Table 1D), and all the genes (22810) represented on the ATH1 chip were set as input lists for the categorization algorithm. The depicted value on each of the $x$ axes represents the quotient of "the number of genes annotated to terms of the respective categorization class" divided by "the total number of genes from the input list annotated to any term in this ontology $(N)$ " in \%. (A) Categorization class "cellular component". (B) Categorization class "biological process". (C) Categorization class "molecular function". plastids are reduced. Not unexpectedly, in the class "biological process", genes with GO annotations "response to (a)biotic stimuli" and "response to stress" were typically found in the group of SAR up-regulated genes (Figure 1B). Furthermore, the functional categories "signal transduction", "transport", and "protein metabolism" were highly represented in the group of $\mathrm{SAR}^{+}$genes, whereas the categories "developmental processes" and "DNA or RNA metabolism" were underrepresented. The category "electron transport and energy pathways" was relatively prominent among the $\mathrm{SAR}^{-}$genes (Figure 1B). Thus, the relative distributions of GO categories from the class "biological processes" indicated that stimulus- and stress-related signal transduction events, transport processes and protein metabolism are prominent features of the
SAR state, whereas certain developmental, nucleic acid metabolic, and energy-related events might be reduced in SAR-induced plants. From the GO categories grouped into the class "molecular function", "kinase activity", "protein binding", "nucleotide binding", "receptor binding", and "transporter activity" were overrepresented in the $\mathrm{SAR}^{+}$gene cluster, whereas "DNA or RNA/nucleic acid binding" was poorly represented (Figure 1C). Again, this might emphasize the importance of signal transduction events such as protein phosphorylation and protein-ligand interactions for SAR.

In the cluster of SAR ${ }^{-}$genes, the relatively high abundance of the GO annotation "hydrolase activity" was one of the most obvious features (Figure 1C). Moreover, when examining the 
specific functional annotation of genes in this cluster, two other trends became apparent. First, several genes belonging to the xyloglucan endotransglucosylase/hydrolase (XTH), the (fasciclinlike) arabinogalactan protein (AGP), the expansin-like protein, the extensin-like protein, and the polygalacturonase families were among the genes most strongly down-regulated during SAR (Table 4). Members of these gene families encode proteins associated with the extracellular matrix and/or the cell wall and have important functions in the rearrangement of cell wall components, wall loosening, cell elongation, and cell growth. For instance, members of the XTH family are involved in xyloglucan endotransglucosylation and/or in xyloglucan hydrolysis. These enzymatic activities can contribute to primary cell growth by restructuring and loosening the xyloglucan network, thereby enabling cell expansion (Rose et al., 2002). Two of the four XTH genes markedly down-regulated during SAR, XTH4 and XTH31 (Table 4), code for proteins that have been experimentally identified as constituents of the cell wall proteome in Arabidopsis hypocotyls (Irshad et al., 2008). The strongly SAR down-regulated EXLA1 gene belongs to the expansin multigene family. The presence of EXLA1 protein in the Arabidopsis cell wall has also been experimentally verified (Irshad et al., 2008). Expansins directly modify the mechanical properties of plant cell walls leading to turgor-driven cell extension (Li et al., 2002). Another class of extracellular proteins implicated in plant growth and development are the hydroxyproline-rich and highly glycosylated AGPs (Schultz et al., 2002). Several AGPs, among them the three fasciclin-like AGPs (FLAs) FLA8, FLA9, and FLA13, belong to the genes most highly downregulated following SAR induction (Table 4). FLAs have, in addition to predicted AGP-like glycosylated regions, putative cell adhesion domains known as fasciclin domains (Johnson et al., 2003). Together, these examples indicate that the SAR state is associated with a marked down-regulation of various genes involved in cell wall modification, cell growth and development (Table 4).
The cluster of $\mathrm{SAR}^{-}$genes also contained several genes involved in glucosinolate and sinapoylester production (Table 5). These include genes encoding regulatory components or enzymes of indolic glucosinolate biosynthesis such as the MYB transcription factor MYB34 and the cytochrome P450 CYP79B3 that converts $\operatorname{Trp}$ to the indolic glucosinolate precursor indole-3acetaldoxime (Glawischnig et al., 2004; Celenza et al., 2005), and of aliphatic glucosinolate biosynthesis such as the flavindependent monooxygenases $\mathrm{FMO}_{\mathrm{GS}-\mathrm{Ox} 1}$ and $\mathrm{FMO}_{\mathrm{GS}-\mathrm{Ox} 3}$ that oxidize Met-derived methylthioalkyl glucosinolates to methylsulfinylalkyl glucosinolates (Li et al., 2008), or the 2-oxoglutaratedependent dioxygenase AOP2 involved in the conversion of methylsulfinylalkyl to alkenyl glucosinolates (Table 5A) (Neal et al., 2010). Moreover, among the most prominently SAR downregulated genes are SCPL8, SCPL10, and SCPL13 (Table 5B), encoding serine carboxypeptidase-like proteins that act as sinapoyltransferases to generate sinapoylmalate, sinapoylanthocyanins, and 1,2-disinapoyl-glucose derivatives, respectively (Stehle et al., 2009; Fraser and Chapple, 2011). Sinapoylesters and glucosinolates are among the most abundant secondary metabolites produced in Arabidopsis in the course of normal growth and development (Stehle et al., 2009; Sønderby et al., 2010). The reduced expression of genes involved in the constitutive production of major secondary metabolites in SAR-induced compared with control plants again supports the hypothesis that SAR represents a state of diminished vegetative growth.

Together, the marked down-regulation of genes with presumed roles in cell wall modification, cell growth and the constitutive production of secondary metabolites (Tables 4,5 ), the overrepresentation of annotated chloroplast functions among SAR down-regulated genes (Figure 1A), and the strong upregulation of stimulus-, stress- and defense-related genes during SAR (Figure 1B) indicate that, compared with control plants, SAR-induced plants reallocate a part of their physiological activity from vegetative growth towards particular defense-associated

Table 4 | Genes associated with cell wall remodelling, cell extension, and growth belong to the most strongly down-regulated genes during SAR.

\begin{tabular}{|c|c|c|c|c|}
\hline Locus & Name & Gene description & {$[P / \mathrm{M}]_{\mathrm{SAR}}$} & $\begin{array}{l}\text { Rank among down- } \\
\text { regulated genes }\end{array}$ \\
\hline At3g45970 & EXLA1 & Expansin-like $A 1 *$ & 0.14 & 11 \\
\hline At2g45470 & FLA8 & Fasciclin-like arabinogalactan-protein 8 & 0.18 & 15 \\
\hline At2g06850 & XTH4 & Xyloglucan endotransglucosylase/hydrolase* & 0.18 & 16 \\
\hline At3g06770 & - & polygalacturonase (pectinase)* & 0.20 & 17 \\
\hline At2g14890 & AGP9 & Arabinogalactan protein 9 /putative proline-rich protein & 0.21 & 23 \\
\hline At2g47930 & AGP26 & Arabinogalactan protein 26 & 0.22 & 26 \\
\hline At1g12090 & $E L P$ & Extensin-like protein & 0.23 & 32 \\
\hline At5g44130 & FLA13 & Fasciclin-like arabinogalactan-protein 13 & 0.24 & 39 \\
\hline At3g44990 & ХTH31 & Xyloglucan endotransglucosylase/hydrolase* & 0.24 & 43 \\
\hline
\end{tabular}

Genes with asterisks encode proteins experimentally verified as cell wall constituents. 
Table 5 | Genes involved in the biosynthesis of major constitutively produced secondary metabolites are down-regulated during SAR.

\begin{tabular}{|c|c|c|c|c|}
\hline Locus & Name & Gene description & $P / \mathrm{M}$ & $\begin{array}{l}\text { Rank among down- } \\
\text { regulated genes }\end{array}$ \\
\hline \multicolumn{5}{|l|}{ A } \\
\hline At4g03060 & AOP2 & $\begin{array}{l}\text { 2-oxoglutarate-dependent dioxygenase, ALKENYL HYDROXALKYL PRODUCING 2, } \\
\text { aliphatic glucosinolate biosynthesis, conversion of methylsulfinylalkyl } \\
\text { glucosinolates to alkenyl glucosinolates, not functional in Col-0 }\end{array}$ & 0.27 & 72 \\
\hline At1g65860 & FMO GS-OX1 & $\begin{array}{l}\text { FLAVIN-MONOOXYGENASE GLUCOSINOLATE S-OXYGENASE 1, aliphatic } \\
\text { glucosinolate biosynthesis, conversion of methylthioalkyl glucosinolates to } \\
\text { methylsulfinylalkyl glucosinolates }\end{array}$ & 0.34 & 163 \\
\hline At1g62560 & FMO GS-OX3 & $\begin{array}{l}\text { FLAVIN-MONOOXYGENASE GLUCOSINOLATE S-OXYGENASE 3, aliphatic } \\
\text { glucosinolate biosynthesis, conversion of methylthioalkyl glucosinolates to } \\
\text { methylsulfinylalkyl glucosinolates }\end{array}$ & 0.36 & 215 \\
\hline At2g22330 & CYP79B3 & $\begin{array}{l}\text { Cytochrome P450 monooxygenase, converts Trp to indole-3-acetaldoxime (IAOx), a } \\
\text { precursor to IAA and indole glucosinolates }\end{array}$ & 0.41 & 370 \\
\hline \multicolumn{5}{|l|}{ B } \\
\hline At2g22980 & SCPL13 & $\begin{array}{l}\text { Serine carboxypeptidase-like (SCPL) protein; sinapoylglucose:sinapoylglucose } \\
\text { sinapoyltransferase }\end{array}$ & 0.11 & 5 \\
\hline At2g23000 & SCPL 10 & SCPL protein; anthocyanin sinapoyltransferase & 0.22 & 28 \\
\hline At2g22990 & SCPL8/SNG1 & SCPL protein; sinapoylglucose:malate sinapoyltransferase & 0.30 & 100 \\
\hline
\end{tabular}

(A) Genes associated with glucosinolate biosynthesis. (B) Sinapoyltransferase genes involved in sinapoylester biosynthesis.

processes that confer broad-spectrum disease resistance (see below).

\section{REGULATORY PRINCIPLES UNDERLYING SAR GENE EXPRESSION}

Having categorized defined groups of SAR up- and downregulated genes, we next aimed to combine our SAR expression data with further transcriptional information to elucidate regulatory principles that govern the SAR response. We used the FIRe software, an Excel ${ }^{\circledR}$ macro designed for rapid microarray data analysis (Garcion et al., 2006), to assemble the SAR expression data with expression data from other, publicly available microarray experiments describing the impact of various defense-, stress-, and hormone-related stimuli on gene expression in Arabidopsis plants. Information about the employed microarray data, the experimenters, and the experimental setup underlying each data set are summarized in Table 6.

The information drawn from these microarray experiments is based on two distinct types of comparisons. In most experiments, Arabidopsis wild-type plants were exogenously treated with a chemical stimulus and the gene expression values of stimulus-treated plants or leaf tissue was compared to the values resulting from an adequate mock-treatment. In this way, we could acquire information about the impact of exogenous application of defense and stress hormones or their derivatives [SA, methyl jasmonate (MeJA), abscisic acid (ABA)], oxidative stress $\left(\mathrm{H}_{2} \mathrm{O}_{2}\right)$, the resistance-enhancing chemical BTH, which is often considered as an SA analogue (Lawton et al., 1996;
Wang et al., 2006; Canet et al., 2010), and flg22-treatment, a 22 mer peptide corresponding to the elicitor-active domain of the bacterial PAMP flagellin (Gomez-Gomez et al., 1999), on gene expression (Table 6, Figures 2-7; microarray designations "BTH", "SA", "MeJA", " $\mathrm{H}_{2} \mathrm{O}_{2}$ ", “ABA", "flg22"). Similarly, one experiment investigated the impact of Psm inoculation on gene expression (designation "Psm"). In contrast to our SAR microarray data (designation "SAR") that describes systemic changes in $2^{\circ}$, non-inoculated leaves at 48 hours post inoculation (hpi), this experiment yielded information about the local changes in gene expression at the site of pathogen inoculation ( $1^{\circ}$ leaves $)$ at 24 hpi. For all microarray experiments, we calculated the means of normalized expression values from the stimulus replicates and divided them by the means of the respective mock-values. This yielded, in analogy to the $[P / M]_{S A R}$ ratios for the SAR experiment, stimulus to mock ratios $[\mathrm{S} / \mathrm{M}]_{\text {stimulus }}$ that quantitatively indicated by which factors genes were differently expressed following application of the exogenous stimulus compared with the mock-control in wild-type Col-0 plants (Figures 2-7).

The microarray experiment 2 (Table 6) that investigated the impact of Psm leaf inoculation on local gene expression yielded two kinds of information: the ratio Psm/mock in Col-0 $\left([\mathrm{S} / \mathrm{M}]_{\text {Psm }}\right.$; microarray $\left.2 \mathrm{a}\right)$, and expression ratios of Psm-treated wild-type samples to different Psm-treated mutant samples ([Col/mutant $]_{\text {Psm; }}$ microarray $\left.2 \mathrm{~b}\right)$. We evaluated the expression data from sid2 which is defective in ICS1 and, consequently, pathogen-induced SA production (Nawrath and Métraux, 1999; 
Table 6 | Publicly available microarray data sets ("microarrays 1-7") used in this study.

\begin{tabular}{|c|c|c|c|c|c|}
\hline Microarray & Name & Experimenter & Experiment description & Designation & Depicted value \\
\hline $2 a$ & NASCARRAYS-454 & $\begin{array}{l}\text { Mitra, Glazebrook } \\
\text { (Wang et al., 2008) }\end{array}$ & $\begin{array}{l}\text { Leaf inoculation (syringe infiltration) of } \\
4-5 \text { week-old Col-0 plants with PSm (OD } \\
0.002 \text { ), inoculated leaves harvested } 24 \\
\text { hpi, plants grown in soil under a } 12 / 12-\mathrm{h} \\
\text { light/dark cycle at } 22^{\circ} \mathrm{C}\end{array}$ & "Psm" & $\begin{array}{l}\text { Col-0-Psm/Col-0-mock = } \\
{[\mathrm{S} / \mathrm{M}]_{\text {Psm }}}\end{array}$ \\
\hline $2 b$ & NASCARRAYS-454 & $\begin{array}{l}\text { Mitra, Glazebrook } \\
\text { (Wang et al., 2008) }\end{array}$ & $\begin{array}{l}\text { Leaf inoculation (syringe infiltration) of } \\
4-5 \text { week-old Col-0 or mutant plants with } \\
\text { Psm (OD } 0.002 \text { ), inoculated leaves } \\
\text { harvested } 24 \mathrm{hpi} \text {, plants grown in soil } \\
\text { under a } 12 / 12 \text {-h light/dark cycle at } 22^{\circ} \mathrm{C}\end{array}$ & "Col / mutant" & $\begin{array}{l}\text { Col-0-Psm/mutant-Psm } \\
=\left[\mathrm{Col} / \text { mutant }_{\mathrm{Psm}}\right.\end{array}$ \\
\hline 3 & E-GEOD-3984 & $\begin{array}{l}\text { Thibaud-Nissen } \\
\text { (Thibaud-Nissen et al., } \\
\text { 2006) }\end{array}$ & $\begin{array}{l}1 \mathrm{mM} \text { SA in } 0.01 \% \text { Silwet, } \\
\text { spray-treatment of } 3-4 \text { week-old, } \\
\text { non-flowering Col-0 plants, leaf samples } \\
\text { harvested } 2 \mathrm{~h} \text { post treatment }\end{array}$ & "SA" & $\mathrm{SA} /$ mock $=[\mathrm{S} / \mathrm{M}]_{\mathrm{SA}}$ \\
\hline 4 & NASCARRAYS-174 & $\begin{array}{l}\text { Goda, Yoshida, } \\
\text { Shimada } \\
\text { (Goda et al., 2008) }\end{array}$ & $\begin{array}{l}7 \text { day-old Col-0 seedlings grown in MS } \\
\text { liquid medium under constant light at } \\
22^{\circ} \mathrm{C} \text { were treated with } 10 \mu \mathrm{M} \text { MeJA, } \\
\text { leaf samples at } 3 \mathrm{~h} \text { post treatment were } \\
\text { considered }\end{array}$ & "JA" & $\mathrm{JA} /$ mock $=[\mathrm{S} / \mathrm{M}]_{\mathrm{JA}}$ \\
\hline 7 & NASCARRAYS-123 & $\begin{array}{l}\text { Scheel, Brunner, } \\
\text { Westphal }\end{array}$ & $\begin{array}{l}\text { Surface-treatment of leaves of } 5 \\
\text { week-old Col-0 plants with } 1 \mathrm{mM} \text { flg } 22 \\
\text { peptide, plants grown on soil at } 22^{\circ} \mathrm{C} \\
\text { under a } 8 / 16 \text { hour light/dark regime, leaf } \\
\text { samples } 4 \mathrm{~h} \text { post treatment were } \\
\text { considered }\end{array}$ & "flg22" & $\mathrm{flg} 22 / \mathrm{mock}=[\mathrm{S} / \mathrm{M}]_{\mathrm{flg} 22}$ \\
\hline
\end{tabular}

Sources, experimenters, relevant literature citations, and experimental descriptions are given.

The designation of each experiment and the value depicted in the Figures 2-7 are also indicated.

Wildermuth et al., 2001), SA insensitive npr1 defective in the transcriptional co-activator and SA receptor NPR1 (Durrant and Dong, 2004; Wu et al., 2012), pad4 defective in the lipase-like defense regulator PHYTOALEXIN-DEFICIENT4 (Jirage et al., 1999), ethylene-insensitive ein2 (Alonso et al., 1999), and JA insensitive coil defective in the JA receptor CORONATINE INSENSITIVE1 (Katsir et al., 2008). The $[\mathrm{Col} / \text { mutant }]_{\text {Psm }}$ ratios could be used to assess at the genetic level whether Psm-induced gene expression was dependent on SA accumulation (sid2), SA perception (npr1), JA perception (coil), and ET perception (ein2) (Figures 2-7).

We now assembled the $[P / M]_{\text {SAR }}$ ratios for each gene from the SAR experiment with the corresponding $[\mathrm{S} / \mathrm{M}]$ or $[\mathrm{Col} / \text { mutant }]_{\mathrm{Psm}}$ ratios from the other microarray experiments 


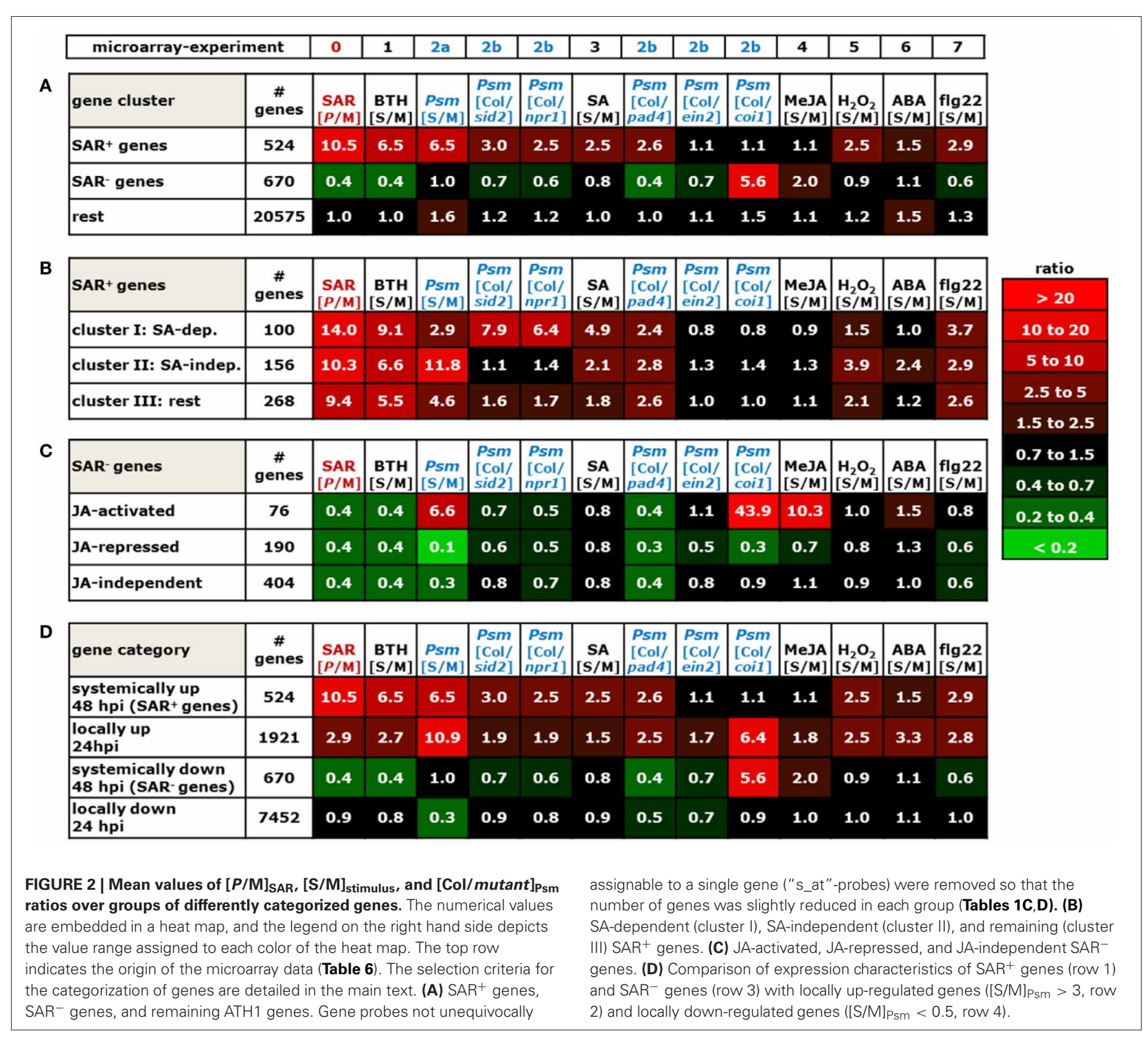

using the "merge" macro of the FIRe program (Garcion et al., 2006). This yielded an Excel ${ }^{\circledR}$ table in which the gene expression information from all the experiments listed in Table 6 for the ATH1 genes was brought together. Some Affymetrix probes (labeled "s_at") hybridize to two or more related genes (Redman et al., 2004). These non-gene specific gene probes had been eliminated in some of the public microarray data used, and we consequently also deleted them from our merged Excel ${ }^{\circledR}$ list. The genes from our list were then grouped into different categories according to evaluation criteria outlined below (Figure 2), and excerpts of the Excel ${ }^{\circledR}$ data set relating to these categories are depicted in Figures 3-7. In addition to $[P / M]_{S A R}$ ratios, the normalized expression values of the genes depicted in Figures 3-7 for each of the three replicate SAR experiments is provided in an accompanying Excel ${ }^{\circledR}$ data file (Supplemental material).
Before considering above-mentioned gene categories, however, we discuss expression information of a specific example, the classical SAR marker gene PR1 (Figure 3, top row), to illustrate the gene regulatory information that we have drawn from the merged data set. $P R 1$ is the most prominently upregulated $\mathrm{SAR}^{+}$gene $\left([P / \mathrm{M}]_{\mathrm{SAR}}=160.2\right)$, and its expression is, as reported in previous studies (Delaney et al., 1995; Lawton et al., $1996)$, enhanced by exogenous BTH $\left([\mathrm{S} / \mathrm{M}]_{\mathrm{BTH}}=46.1\right)$ and SA $\left([\mathrm{S} / \mathrm{M}]_{\mathrm{SA}}=5.6\right)$ (Figure 3). Local inoculation with Psm also increases $P R 1$ expression at $24 \mathrm{hpi}$, leading to an $\left([\mathrm{S} / \mathrm{M}]_{\mathrm{Psm}}\right.$ ratio of 5.5 in the "Psm" experiment. The $[\mathrm{Col} / \text { sid2 }]_{\mathrm{Psm}}$ (5.3) and the $[\mathrm{Col} / \text { npr } 1]_{\text {Psm }}$ (5.6) ratios reveal that PR1 expression upon Psminoculation in the two mutants does not exceed $P R 1$ expression in Col-0 mock-control plants, indicating that $P$. syringae-induced PR1 expression fully depends on ICS1-mediated SA biosynthesis 


\begin{tabular}{|c|c|c|c|c|c|c|c|c|c|c|c|c|c|c|c|}
\hline gene locus & $\begin{array}{c}\text { gene } \\
\text { name }\end{array}$ & $\begin{array}{c}\text { SAR } \\
{[P / M]}\end{array}$ & \begin{tabular}{|c|} 
BTH \\
{$[\mathrm{S} / \mathrm{M}]$}
\end{tabular} & $\begin{array}{l}\text { Psm } \\
{[\mathrm{S} / \mathrm{M}]}\end{array}$ & \begin{tabular}{|l|} 
Psm \\
{$[\mathrm{Col} /$} \\
sid2] \\
\end{tabular} & \begin{tabular}{|l|} 
Psm \\
{$[\mathrm{Col} /$} \\
$n p r 1]$
\end{tabular} & \begin{tabular}{|c|} 
SA \\
{$[\mathrm{S} / \mathrm{M}]$}
\end{tabular} & $\begin{array}{c}\text { Psm } \\
{[\mathrm{Col} /} \\
\text { pad4] }\end{array}$ & $\begin{array}{l}\text { Psm } \\
{[\mathrm{Col} /} \\
\text { ein2] }\end{array}$ & $\begin{array}{l}\text { Psm } \\
{[\mathrm{Col} /} \\
\text { coi1] }\end{array}$ & \begin{tabular}{l|l} 
MejA \\
{$[S / M]$}
\end{tabular} & \begin{tabular}{|l|}
$\mathrm{H}_{2} \mathrm{O}_{2}$ \\
{$[\mathrm{~S} / \mathrm{M}]$} \\
\end{tabular} & \begin{tabular}{|c|} 
ABA \\
{$[S / M]$}
\end{tabular} & $\begin{array}{ll}\mathbf{f l g 2 2} \\
{[\mathrm{S} / \mathrm{M}]}\end{array}$ & gene description \\
\hline At2g14610 & PR1 & 160.2 & 46.1 & 5.5 & 5.3 & 5.6 & 5.6 & 2.3 & 0.8 & 1.0 & 1.2 & 0.9 & 1.1 & 1.1 & PATHOGENESIS-RELATED GENE 1 \\
\hline At1g02450 & NIMIN-1 & 133.9 & 26.6 & 2.0 & 25.0 & 18.0 & 32.9 & 2.0 & 0.6 & 0.5 & 0.4 & 0.7 & 1.1 & 1.3 & NIM1-INTERACTING 1 \\
\hline At3g11340 & UGT76B1 & 92.6 & 21.8 & 15.1 & 16.4 & 6.6 & 80.4 & 2.3 & 1.3 & 2.0 & 2.6 & 1.0 & 0.8 & 7.3 & $\begin{array}{l}\text { UDP-glycosyltransferase, } \\
\text { conjugates isoleucic acid }\end{array}$ \\
\hline At5g22570 & WRKY38 & 63.1 & 29.0 & 4.2 & 43.7 & 85.2 & 50.6 & 0.8 & 0.4 & 1.8 & 1.7 & 0.9 & 0.7 & 2.2 & WRKY transcription factor \\
\hline At2g26400 & ARD3 & 48.6 & 41.0 & 19.4 & $\mid 180.8$ & 110.8 & 15.7 & 7.1 & 1.0 & 0.9 & 0.8 & 1.2 & 0.7 & 0.9 & $\begin{array}{l}\text { acireductone dioxygenase (ARD) } \\
\text { family }\end{array}$ \\
\hline At1g03850 & GRXS13 & 40.1 & 32.2 & 7.5 & 6.7 & 6.7 & 30.7 & 6.6 & 0.9 & 0.6 & 0.9 & 1.9 & 0.5 & 1.1 & GLUTAREDOXIN 13 \\
\hline At2g04450 & NUDX6 & 38.7 & 26.8 & 5.5 & 3.8 & 3.4 & 2.6 & 5.3 & 0.5 & 0.6 & 0.6 & 2.2 & 0.7 & 0.9 & $\begin{array}{l}\text { NUDIX HYDROLASE HOMOLOG 6, } \\
\text { NADH pyrophosphatase activity }\end{array}$ \\
\hline At4g23810 & WRKY53 & 26.8 & 18.2 & 3.3 & 4.3 & 3.2 & 2.9 & 1.9 & 0.5 & 0.4 & 0.5 & 2.2 & 0.7 & 4.5 & WRKY transcription factor \\
\hline At4g35180 & LHTZ & 23.6 & 41.1 & 11.4 & 30.8 & 7.2 & 17.3 & 2.0 & 0.7 & 1.3 & 1.7 & 5.0 & 1.5 & 20.0 & lysine/histidine-like transporter 7 \\
\hline At3g28510 & - & 17.9 & $|133.3|$ & 9.6 & 52.1 & 40.2 & 11.4 & 9.6 & 1.1 & 0.8 & 0.2 & 1.2 & 0.2 & 1.5 & $\begin{array}{l}\text { P-loop containing nucleoside } \\
\text { triphosphate hydrolase }\end{array}$ \\
\hline At2g47130 & SDR3 & 9.6 & 6.9 & 3.6 & 3.5 & 3.4 & 3.1 & 3.2 & 1.0 & 0.9 & 0.7 & 1.2 & 0.5 & 2.0 & $\begin{array}{c}\text { short chain } \\
\text { dehydrogenase/reductase }\end{array}$ \\
\hline At3g56400 & WRKYTO & 9.1 & 2.8 & 3.4 & 3.9 & 2.1 & 3.3 & 2.0 & 1.0 & 1.0 & 0.9 & 2.8 & 0.8 & 0.9 & WRKY transcription factor \\
\hline At $4 \mathrm{~g} 39830$ & - & 4.5 & 22.5 & 5.7 & 5.2 & 7.0 & 2.9 & 5.1 & 1.0 & 0.6 & 1.0 & 1.4 & 0.7 & 6.6 & $\begin{array}{l}\text { cupredoxin superfamily protein, } \\
\text { putative L-ascorbate oxidase }\end{array}$ \\
\hline At1g11310 & MLO2 & 4.5 & 1.8 & 3.7 & 4.5 & 3.6 & 3.1 & 3.6 & 1.0 & 0.9 & 0.8 & 2.8 & 0.7 & 2.0 & $\begin{array}{l}\text { MILDEW RESISTANCE LOCUS O } 2 / \\
\text { POWDERY MILDEW RESISTANT } 2\end{array}$ \\
\hline At3g53150 & UGT73D1 & 3.7 & 12.2 & 9.6 & 26.3 & 11.4 & 3.0 & 10.5 & 0.8 & 0.7 & 0.8 & 1.1 & 1.2 & 12.0 & UDP-glycosyltransferase \\
\hline At2g19190 & FRK1 & 3.5 & 21.7 & 9.8 & 20.0 & 23.4 & 3.0 & 4.9 & 0.9 & 0.5 & 0.2 & 0.6 & 2.2 & 92.2 & $\begin{array}{c}\text { FLG22-INDUCED } \\
\text { RECEPTOR-LIKE KINASE } 1\end{array}$ \\
\hline At1g64280 & NPR1 & 2.6 & 2.2 & 2.2 & 2.2 & 1.9 & 1.8 & 1.7 & 1.2 & 1.0 & 0.9 & 1.8 & 0.8 & 1.3 & $\begin{array}{l}\text { NONEXPRESSER OF PR GENES 1, } \\
\text { sA signal transduction, SA receptor }\end{array}$ \\
\hline
\end{tabular}

FIGURE 3 | Values of $[P / \mathrm{M}]_{\mathrm{SAR}},[\mathrm{S} / \mathrm{M}]_{\text {stimulus, }}$ and $[\mathrm{Col} / \text { mutant }]_{\mathrm{Psm}}$ ratios for individual genes of the group of SA-dependent (cluster I) $\mathbf{S A R}^{+}$genes (Figure 2B). The data for the NPR1 gene is also included into the list. The gene names of genes indispensable for SAR are depicted in red. The legend for the heat map representation is depicted in Figure 2. and on NPR1-mediated downstream signaling. Thus, exogenous SA is sufficient and endogenous SA accumulation following bacterial inoculation is necessary to induce $P R 1$ expression. By contrast, induction of $P R 1$ expression is independent of JA signaling, because exogenous MeJA $\left([\mathrm{S} / \mathrm{M}]_{\mathrm{JA}}=1.2\right)$ does not elevate PR1 levels, and the $[\mathrm{Col} / \text { coil }]_{\text {Psm }}$ ratio equals 1.0 , indicating identical $P$. syringae-induced expression of the gene in the Col-0 wild-type and in JA-insensitive coil. Further, the $[\mathrm{Col} / \text { pad4 }]_{\mathrm{Psm}}$ ratio equals 2.3 , indicating an attenuated but not a fully compromised Psm-induced expression of PR1 in pad4 and thus a partial PAD4 dependency (Figure 3). Finally, PR1 expression occurs virtually independently of ET signaling $\left([\mathrm{Col} / \text { ein } 2]_{\mathrm{Psm}}=0.8\right)$ and is not stimulated by exogenous $\mathrm{H}_{2} \mathrm{O}_{2}\left([\mathrm{~S} / \mathrm{M}]_{\mathrm{H} 2 \mathrm{O} 2}=0.9\right)$, ABA $\left([\mathrm{S} / \mathrm{M}]_{\mathrm{ABA}}=1.1\right)$, or flg22 $\left([\mathrm{S} / \mathrm{M}]_{\mathrm{flg} 22}=1.1\right)$ (Figure 3$)$.

To draw information about regulatory principles of gene expression in the clusters of SAR up-regulated, SAR downregulated, and remaining ATH1 genes, we first determined the mean values of $[P / M]_{\text {SAR }},[\mathrm{S} / \mathrm{M}]_{\text {stimulus }}$, and $[\mathrm{Col} / \text { mutant }]_{\mathrm{Psm}}$ ratios for all the genes from each category. Compared with the rest of the ATH1 genes, the $\mathrm{SAR}^{+}$genes exhibited, in addition to a strong average expression in $2^{\circ}$ leaves of SAR-induced plants $\left(\right.$ mean $\left.[P / M]_{\text {SAR }}=10.5\right)$, a marked average up-regulation in leaves of BTH-treated plants and in Psm-inoculated leaves (Figure 2A). To a lesser extent, the average expression of these genes was stimulated by the SA pathway, $\mathrm{H}_{2} \mathrm{O}_{2}$, and flg22, and positively influenced by functional $P A D 4$. Moreover, a small average inducing stimulus of $\mathrm{ABA}$ on the expression of $\mathrm{SAR}^{+}$genes was obvious, and the JA- and ET- pathways had virtually no influence on the average $\mathrm{SAR}^{+}$gene expression patterns. By contrast, the genes down-regulated in SAR (mean $[P / M]_{\mathrm{SAR}}=0.4$ ) exhibited a completely different regulatory pattern. On average, these genes were markedly down-regulated by BTH and PAD4, and to lesser extent, by SA signaling, ET-signaling, and flg22treatment. Remarkably, the average expression of the SAR ${ }^{-}$genes was strongly stimulated by JA signaling $\left([\mathrm{Col} / \mathrm{coil}]_{\mathrm{Psm}}=5.6\right)$ (Figure 2A).

The positive effect of BTH, SA signaling, and PAD4 on the average expression of $\mathrm{SAR}^{+}$genes is consistent with the facts that BTH induces plant resistance patterns similar to SAR (Lawton et al., 1996), that SA is a central signal for SAR (Wildermuth et al., 2001; Mishina and Zeier, 2006), and that the PAD4 defense regulator is required for SAR establishment (Mishina and Zeier, 2006; Jing et al., 2011). One of the hallmarks of SAR is systemic SA accumulation at the onset of SAR (Métraux et al., 1990; Shulaev et al., 1995; Attaran et al., 2009), and increased levels of SA in $2^{\circ}$ leaves upon SAR induction is closely associated with increased expression of SAR-related genes (Shulaev et al., 1995; Mishina and Zeier, 2006). We therefore determined whether all or only a sub-fraction of the $\mathrm{SAR}^{+}$genes are indeed up-regulated by SA. To categorize SA-regulated genes, we aimed at selecting only 


\begin{tabular}{|c|c|c|c|c|c|c|c|c|c|c|c|c|c|c|c|}
\hline gene locus & $\begin{array}{l}\text { gene } \\
\text { name }\end{array}$ & \begin{tabular}{c|} 
SAR \\
{$[P / M]$}
\end{tabular} & $\begin{array}{c}\text { BTH } \\
{[\mathrm{S} / \mathrm{M}]}\end{array}$ & \begin{tabular}{|l|} 
Psm \\
{$[\mathrm{S} / \mathrm{M}]$}
\end{tabular} & $\begin{array}{l}\text { Psm } \\
{[\mathrm{Col} /} \\
\text { sid2] }\end{array}$ & $\begin{array}{l}\text { Psm } \\
{[\mathrm{Col} /} \\
\text { npr1] }\end{array}$ & \begin{tabular}{|c|} 
SA \\
{$[\mathbf{S} / \mathrm{M}]$}
\end{tabular} & $\begin{array}{l}\text { Psm } \\
{[\mathrm{Col} /} \\
\text { pad4] }\end{array}$ & \begin{tabular}{l|} 
Psm \\
{$[\mathrm{Col} /$} \\
ein2]
\end{tabular} & $\begin{array}{l}\text { Psm } \\
{[\mathrm{Col} /} \\
\text { coi1 }]\end{array}$ & \begin{tabular}{|l|l} 
MejA \\
{$[S / M]$}
\end{tabular} & $\begin{array}{l}\mathrm{H}_{2} \mathrm{O}_{2} \\
{[\mathrm{~S} / \mathrm{M}]}\end{array}$ & \begin{tabular}{c|c|}
$\mathbf{A B A}$ \\
{$[\mathrm{S} / \mathrm{M}]$}
\end{tabular} & $\begin{array}{l}\text { flg22 } \\
{[\mathrm{S} / \mathrm{M}]}\end{array}$ & gene description \\
\hline At $3 g 22600$ & - & 89.1 & 12.8 & 8.8 & 1.2 & 1.5 & 1.2 & 2.6 & 1.1 & 1.0 & 0.7 & 0.8 & 3.0 & 2.4 & $\begin{array}{c}\text { lipid-transfer protein/seed storage } 2 \mathrm{~S} \\
\text { albumin superfamily protein }\end{array}$ \\
\hline At2g43570 & $\mathrm{CHI}$ & 42.5 & 9.1 & 8.1 & 1.2 & 1.5 & 1.1 & 2.5 & 0.9 & 1.0 & 1.2 & 0.8 & 22.3 & 2.8 & putative chitinase \\
\hline At5g13320 & PBS3 & 38.0 & 21.9 & 40.7 & 1.4 & 1,6 & 1.4 & 6.2 & 1.1 & 1.3 & 1.8 & 0.9 & 3.2 & 7.4 & $\begin{array}{c}\text { GH3 family protein, p-hydroxybenzoyl } \\
\text { amino acid synthetase activity }\end{array}$ \\
\hline At1g57630 & - & 35.1 & 36.9 & 25.1 & 1.2 & 1.4 & 2.0 & 4.9 & 1.4 & 1.3 & 0.9 & 1.7 & 3.3 & 10.8 & $\begin{array}{c}\text { Toll-Interleukin-Resistance (TIR) } \\
\text { domain family protein }\end{array}$ \\
\hline At5g52640 & HSP9O-1 & 29.8 & 2.7 & 7.9 & 1.2 & 1.6 & 1.2 & 1.9 & 1.3 & 1.2 & 0.5 & 11.9 & 0.8 & 3.1 & HEAT SHOCK PROTEIN 90-1 \\
\hline At2g29460 & GST22 & 27.4 & 14.2 & 38.8 & 0.8 & 0.8 & 3.0 & 1.4 & 2.8 & 6.4 & 9.2 & 3.6 & 12.9 & 6.3 & GLUTATHIONE S-TRANSFERASE 22 \\
\hline At5g39670 & - & 21.1 & 22.6 & 11.8 & 1.1 & 1.3 & 1.3 & 5.8 & 1.0 & 1.0 & 0.7 & 6.3 & 0.5 & 1.8 & Calcium-binding EF-hand family protein \\
\hline At5g20230 & $B C B$ & 20.7 & 13.2 & 5.7 & 0.8 & 1.3 & 1.6 & 1.4 & 0.8 & 1.0 & 1.3 & 13.3 & 2.4 & 1.7 & $\begin{array}{l}\text { BLUE-COPPER-BINDING PROTEIN, } \\
\text { SENESCENCE ASSOCIATED GENE } 14\end{array}$ \\
\hline At3g26830 & $P A D 3$ & 20.0 & 16.2 & 58.0 & 0.7 & 0.9 & 4.1 & 2.4 & 1.9 & 4.2 & 1.9 & 3.4 & 0.7 & 1.8 & $\begin{array}{c}\text { cytochrome P450 CYP71B15, } \\
\text { camalexin biosynthesis }\end{array}$ \\
\hline At4g37370 & CYP81D8 & 15.7 & 5.4 & 12.0 & 1.4 & 2.0 & 7.9 & 3.3 & 1.2 & 1.0 & 0.3 & 28.2 & 1.7 & 2.5 & cytochrome P450 family protein \\
\hline At3g12580 & HSP7O & 12.5 & 2.2 & 4.8 & 1.0 & 1.2 & 1.0 & 1.3 & 1.3 & 1.4 & 1.4 & 14.3 & 6.1 & 2.3 & $\begin{array}{c}\text { HEAT SHOCK PROTEIN 70/ HEAT SHOCK } \\
\text { COGNATE 70-4 (HSC70-4) } \\
\end{array}$ \\
\hline At1g19250 & FMO1 & 12.0 & 3.5 & 81.8 & 0.9 & 1.2 & 1.4 & 5.5 & 3.0 & 2.7 & 1.2 & 0.6 & 0.9 & 1.9 & FLAVIN-DEPENDENT MONOOXYGENASE 1 \\
\hline At1g15520 & PDR12 & 10.3 & 2.8 & 77.6 & 1.3 & 1.6 & 2.8 & 6.4 & 3.4 & 3.6 & 1.6 & 2.2 & 1.0 & 1.9 & $\begin{array}{l}\text { ATP binding cassette transporter } \\
\text { ABCG40, abscisic acid transport }\end{array}$ \\
\hline At1g74710 & ICS 1 & 9.8 & 9.9 & 13.1 & - & 1.0 & 1.0 & 5.4 & 0.9 & 0.9 & 0.7 & 1.1 & 0.9 & 1.6 & $\begin{array}{l}\text { ISOCHORISMATE SYNTHASE 1, } \\
\text { salicylic acid biosynthesis }\end{array}$ \\
\hline At $2 g 38470$ & WRKY33 & 9.3 & 5.6 & 7.9 & 1.3 & 1.4 & 2.0 & 2.9 & 1.1 & 1.0 & 0.9 & 13.6 & 1.0 & 2.8 & $\begin{array}{l}\text { WRKY transcription factor, } \\
\text { regulates camalexin biosynthesis }\end{array}$ \\
\hline At5g59820 & ZAT12 & 6.6 & 6.7 & 15.6 & 1.4 & 1.9 & 1.4 & 2.7 & 1.5 & 1.6 & 1.1 & 5.1 & 2.0 & 4.6 & $\begin{array}{c}\text { putative zinc finger transcription factor, } \\
\text { RESPONSIVE TO HIGH LIGHT } \mathbf{4 1} \\
\end{array}$ \\
\hline At $2 g 29350$ & $S A G 13$ & 5.5 & 6.8 & 19.9 & 0.9 & 1.0 & 0.8 & 2.3 & 1.3 & 1.7 & 1.1 & 1.4 & 17.1 & 1.9 & $\begin{array}{l}\text { senescence-associated gene SAG13, } \\
\text { short-chain alcohol dehydrogenase }\end{array}$ \\
\hline At $2 g 13810$ & $A L D 1$ & 4.8 & 6.0 & 57.1 & 1.3 & 1.3 & 1.6 & 8.6 & 1.1 & 1.8 & 0.6 & 1.0 & 1.0 & 1.9 & $\begin{array}{l}\text { AGD2-like defense response protein 1, } \\
\text { lysine aminotransferase, } \\
\text { pipecolic acid biosynthesis }\end{array}$ \\
\hline At $2 g 30770$ & CYP71A13 & 4.6 & 13.3 & $\mid 107.3$ & 0.9 & 1.2 & 1.6 & 3.9 & 2.7 & 4.2 & 1.8 & 0.9 & 1.0 & 0.9 & $\begin{array}{l}\text { cytochrome P450, indoleacetaldoxime } \\
\text { dehydratase, camalexin biosynhtesis }\end{array}$ \\
\hline At3g28930 & AIG 2 & 3.6 & 3.2 & 8.1 & 1.0 & 0.7 & 1.0 & 1.6 & 3.0 & 7.4 & 2.1 & 3.8 & 0.6 & 0.9 & AvrRpt2-induced gene \\
\hline
\end{tabular}

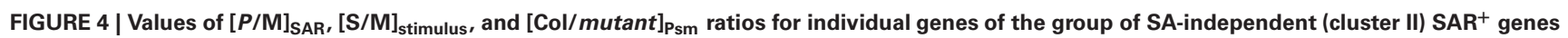
(Figure 2B). The gene names of genes indispensable for SAR are depicted in red. The legend for the heat map representation is depicted in Figure $\mathbf{2}$.

those genes whose induced local expression upon Psm-treatment was severely compromised in sid2. We therefore had to consider genes with increased $[\mathrm{Col} / \text { sid2 }]_{\text {Psm }}$ ratios and first selected genes with $[\mathrm{Col} / \text { sid2 }]_{\mathrm{Psm}}$ ratios $>2$. However, this criterion alone was not sufficient for selection because the genes strongly varied in their $[\mathrm{S} / \mathrm{M}]_{\text {Psm }}$-ratios and thus their Psm-responsiveness. For instance, genes strongly Psm-up-regulated in Col-0 still exhibit considerable Psm-induced up-regulation in sid2 with the criterion $[\mathrm{Col} / \text { sid2 }]_{\mathrm{Psm}}$ ratios $>2$ and thus are only weakly SA dependent. We consequently coupled the $[\mathrm{Col} / \text { sid2 }]_{\mathrm{Psm}}$ ratio to the degree of Psm-responsiveness and defined that only genes with quotients of $[\mathrm{Col} / \text { sid2 }]_{\mathrm{Psm}} /[\mathrm{S} / \mathrm{M}]_{\mathrm{Psm}}>0.67$ were taken. The combination of these two selection criteria provided a set of 100 genes out of $541 \mathrm{SAR}^{+}$genes whose expression was locally $P s m$-inducible in a modest to strong manner and whose Psminduced up-regulation was largely dependent on SID2/ICS1 and thus on endogenous SA. Moreover, most of these genes were also up-regulated by exogenous SA (Figures 2B, 3). To categorize $\mathrm{SAR}^{+}$genes independently expressed from $\mathrm{SA}$, we assembled all the genes with a low $[\mathrm{Col} / \text { sid2 }]_{\mathrm{Psm}}$ ratio $\left([\mathrm{Col} / \text { sid2 }]_{\mathrm{Psm}}<1.5\right)$ that were up-regulated upon Psm inoculation by at least a factor of 3. This selection yielded $156 \mathrm{SA}$-independent $\mathrm{SAR}^{+}$genes (Figures 2B, 4). The remaining $\mathrm{SAR}^{+}$genes (268) were grouped into a third category that mainly consisted of genes partly requiring SID2/ICS1 for Psm-induced expression (partly SA-dependent genes), or of genes not locally up-regulated by Psm at $24 \mathrm{hpi}$ (Figures 2B, 5). Therefore, $\mathrm{SAR}^{+}$genes were categorized into three groups according to their SA-dependent expression: strictly SA-dependent genes (cluster I), SA-independent genes (cluster II), and cluster III genes predominantly consisting of genes with partial SA-dependency. Irrespective of their SA responsiveness, the vast majority of $\mathrm{SAR}^{+}$genes were also up-regulated by exogenous BTH, indicating that the action of the so-called "SA analogue" BTH on gene transcription is significantly broader than the action of SA itself (Figures $\mathbf{2 B}, \mathbf{3}, \mathbf{4}, \mathbf{5}$ ). Similarly, genes down-regulated during biological SAR were generally downregulated by exogenous BTH (Figures 2, 6). These tendencies indicate extensive overlap between the biologically-induced SAR state and the state of enhanced disease resistance after BTH application. Nevertheless, some differences between biological SAR and BTH-treatment existed for the transcription levels of individual genes not affected in biological SAR (Figure 2A, "rest"). Hereunder, $1.8 \%$ of genes were positively $\left([\mathrm{S} / \mathrm{M}]_{\mathrm{BTH}}>3\right)$ and $15.8 \%$ negatively $\left([\mathrm{S} / \mathrm{M}]_{\mathrm{BTH}}<2\right)$ regulated by BTH (specific examples are MAPKKK19, CYP94C1, UGT76E1, ACS2, DXL1, $P R 3$; Figure 7). 


\begin{tabular}{|c|c|c|c|c|c|c|c|c|c|c|c|c|c|c|c|}
\hline gene locus & $\begin{array}{l}\text { gene } \\
\text { name }\end{array}$ & \begin{tabular}{|c|} 
SAR \\
{$[P / M]$}
\end{tabular} & $\begin{array}{c}\text { BTH } \\
{[\mathrm{S} / \mathrm{M}]}\end{array}$ & $\begin{array}{c}\text { Psm } \\
{[\mathrm{S} / \mathrm{M}]}\end{array}$ & $\begin{array}{l}\text { Psm } \\
{[\mathrm{Col} /} \\
\text { sid2] }\end{array}$ & $\begin{array}{l}\text { Psm } \\
\text { [Col/ } \\
\text { npr1] }\end{array}$ & $\begin{array}{c}\text { SA } \\
{[\mathbf{S} / \mathrm{M}]}\end{array}$ & $\left.\begin{array}{l}\text { Psm } \\
{[\mathrm{Col} /} \\
\text { pad4] }\end{array}\right]$ & $\begin{array}{l}\text { Psm } \\
{[\mathrm{Col} /} \\
\text { ein2] }\end{array}$ & $\begin{array}{l}\text { Psm } \\
{[\mathrm{Col} /} \\
\text { coi1] }\end{array}$ & \begin{tabular}{l|l|} 
MejA \\
{$[S / M]$}
\end{tabular} & $\begin{array}{l}\mathrm{H}_{2} \mathrm{O}_{2} \\
{[\mathrm{~S} / \mathrm{M}]}\end{array}$ & \begin{tabular}{|c|} 
ABA \\
{$[S / M]$}
\end{tabular} & $\begin{array}{l}\mathbf{f l g} 22 \\
{[S / M]}\end{array}$ & gene description \\
\hline At1g35230 & AGP5 & $\mid 106.0$ & 16.5 & 8.1 & 3.8 & 4.3 & 2.4 & 7.7 & 0.9 & 0.7 & 0.5 & 1.2 & 2.7 & 1.4 & arabinogalactan protein 5 \\
\hline At3g01830 & - & 66.3 & 58.2 & 28.7 & 1.9 & 2.1 & 3.8 & 4.6 & 1.0 & 1.5 & 0.1 & 11.9 & 1.8 & 14.9 & $\begin{array}{l}\text { Calcium-binding EF-hand family } \\
\text { protein }\end{array}$ \\
\hline At3g57260 & PR2 & 46.1 & 13.7 & 1.0 & 1.1 & 0.9 & 1.1 & 0.6 & 0.3 & 1.3 & 1.5 & 1.5 & 1.0 & 1.2 & $\begin{array}{l}\text { PATHOGENESIS-RELATED GENE 2, } \\
\beta-1,3 \text {-glucanase }\end{array}$ \\
\hline At $4 \mathrm{~g} 11890$ & $A R C K 1$ & 40.4 & 13.6 & 4.6 & 1.9 & 2.0 & 2.8 & 3.5 & 1.0 & 0.8 & 0.5 & 2.0 & 1.6 & 7.5 & protein kinase superfamily protein \\
\hline At5g22570 & PR5 & 38.4 & 18.8 & 1.7 & 1.1 & 1.5 & 1.4 & 3.3 & 1.4 & 1.5 & 1.1 & 1.1 & 1.1 & 0.8 & $\begin{array}{l}\text { PATHOGENESIS-RELATED GENE 5, } \\
\text { osmotin / thaumatin-like protein }\end{array}$ \\
\hline At4g00700 & - & 29.8 & 25.2 & 8.9 & 3.1 & 3.2 & 1.6 & 8.5 & 0.9 & 0.9 & 0.7 & 0.7 & 1.4 & 1.1 & $\begin{array}{l}\text { C2 calcium/lipid-binding plant phos- } \\
\text { phoribosyltransferase family protein }\end{array}$ \\
\hline At2g46400 & WRKY46 & 17.4 & 11.3 & 5.4 & 1.7 & 2.0 & 3.5 & 3.5 & 0.7 & 0.7 & 0.8 & 1.9 & 0.9 & 2.6 & WRKY transcription factor \\
\hline At1g80840 & WRKY4O & 15.6 & 11.4 & 17.5 & 1.7 & 1.4 & 6.3 & 2.3 & 1.4 & 1.8 & 4.2 & 22.4 & 1.4 & 3.6 & WRKY transcription factor \\
\hline At3g52430 & PAD4 & 13.5 & 10.3 & 11.1 & 2.2 & 2.2 & 2.5 & - & 1.1 & 1.0 & 0.9 & 1.4 & 0.4 & 1.1 & $\begin{array}{c}\text { PHYTOALEXIN-DEFICIENT } 4 \text {, } \\
\alpha / \beta \text {-hydrolases superfamily protein }\end{array}$ \\
\hline At1g28480 & GRX480 & 12.7 & 19.4 & 19.5 & 2.5 & 1.3 & 10.4 & 1.6 & 1.2 & 14.0 & 3.2 & 1.8 & 0.6 & 2.3 & glutaredoxin family protein \\
\hline At3g48090 & EDS1 & 11.1 & 7.1 & 2.1 & 1.5 & 1.5 & 2.5 & 2.7 & 0.7 & 0.6 & 0.5 & 1.3 & 0.9 & 1.4 & $\begin{array}{l}\text { ENHANCED DISEASE SUSCEPTIBILITY } \\
1, \alpha / \beta \text {-hydrolases superfamily protein }\end{array}$ \\
\hline At4g31800 & WRKY18 & 10.7 & 23.7 & 7.6 & 3.5 & 2.0 & 9.5 & 1.5 & 0.8 & 1.1 & 2.8 & 3.8 & 0.6 & 2.2 & WRKY transcription factor \\
\hline At5g60900 & $R L K 1$ & 7.9 & 3.4 & 1.8 & 1.8 & 1.3 & 2.7 & 1.4 & 0.9 & 1.0 & 1.3 & 1.0 & 1.3 & 1.2 & receptor-like protein kinase 1 \\
\hline At5g26920 & CBP6Og & 6.5 & 9.3 & 17.0 & 2.1 & 2.6 & 1.5 & 11.7 & 1.0 & 0.7 & 1.4 & 1.7 & 0.7 & 17.0 & calmodulin binding protein 60-like.g \\
\hline At3g11820 & PEN1 & 6.4 & 3.9 & 2.7 & 1.9 & 1.9 & 1.9 & 2.8 & 1.0 & 0.9 & 0.7 & 6.9 & 0.9 & 3.1 & $\begin{array}{c}\text { PENETRATION1, } \\
\text { syntaxin of plants } 121 \text { (SYP121) }\end{array}$ \\
\hline At3g52400 & SYP122 & 5.3 & 8.5 & 8.2 & 1.7 & 2.9 & 1.5 & 6.1 & 1.3 & 0.9 & 1.2 & 1.4 & 0.9 & 5.5 & syntaxin of plants 122 \\
\hline At5g45110 & NPR3 & 4.6 & 3.8 & 4.8 & 2.6 & 1.7 & 6.1 & 3.1 & 0.9 & 0.9 & 1.3 & 5.2 & 0.6 & 2.0 & NPR1-like protein 3, SA receptor \\
\hline At5g14930 & SAG101 & 4.0 & 3.3 & 5.0 & 1.6 & 1.9 & 1.5 & 4.3 & 0.9 & 0.9 & 0.7 & 1.1 & 0.6 & 2.0 & $\begin{array}{c}\text { senescence-associated gene } 101, \\
\text { acyl hydrolase }\end{array}$ \\
\hline At3g45640 & МРК3 & 3.5 & 2.5 & 2.1 & 1.3 & 1.3 & 1.3 & 3.0 & 1.0 & 0.9 & 1.0 & 4.5 & 0.2 & 1.5 & mitogen-activated protein kinase 3 \\
\hline At1g73805 & SARD1 & 3.0 & 9.3 & 7.6 & 3.5 & 2.5 & 4.8 & 5.5 & 1.1 & 0.9 & 0.6 & 1.1 & 0.7 & 1.1 & calmodulin-binding protein-like \\
\hline
\end{tabular}

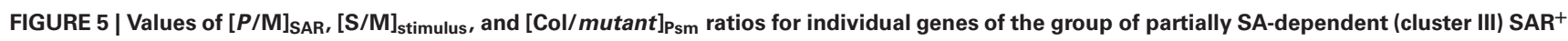
genes (Figure 2B). The gene names of genes indispensable for SAR are depicted in red. The legend for the heat map representation is depicted in Figure $\mathbf{2}$.

On average, the $[\mathrm{Col} / \mathrm{sid} 2]_{\mathrm{Psm}}$ ratios for the SA-dependent $\mathrm{SAR}^{+}$genes, the SA-independent $\mathrm{SAR}^{+}$genes, and the remaining genes amounted to 7.9,1.1, and 1.6, respectively, reflecting strong, virtually absent, and moderate $\mathrm{SA}$ regulation of the respective genes (Figure 2B). The $[\mathrm{Col} / n \text { pr } 1]_{\text {Psm }}$ ratios $(6.4,1.4,1.7)$ paralleled the $[\mathrm{Col} / \text { sid2 }]_{\text {Psm }}$ ratios, confirming above-mentioned influences of the SA pathway on the regulation of the different gene groups (Figure $2 B$ ). The $[S / M]_{S A}$ values exhibited a similar tendency as well (4.9 for SA-dependent, 2.1 for SAindependent, and 1.8. for remaining genes), although some genes of the SA-independent gene cluster showed a moderate responsiveness to exogenous SA (Figure 2B). PAD3 is a typical example of a gene grouped into the SA-independent gene cluster which responded to exogenous SA (Figure 4). We reasoned, however, that in such cases, a $[\mathrm{Col} / \operatorname{sid} 2]_{\mathrm{Psm}}$ ratio close to 1 would provide a more meaningful criterion for SA-independency than an elevated $[\mathrm{S} / \mathrm{M}]_{\mathrm{SA}}$ value, because the $[\mathrm{Col} / \text { sid2 }]_{\mathrm{Psm}}$ ratio results from physiological differences in SA rather than from artificial SA differences caused by exogenous treatment. In general, however, the $[\mathrm{Col} / \text { sid2 }]_{\text {Psm }}$ values paralleled the $[\mathrm{S} / \mathrm{M}]_{S A}$ values remarkably well: SA-dependent genes generally exhibited high values for both parameters (Figure 3), and the majority of SA-independent genes, as exemplified by $C H I, F M O 1$, and SAG13, showed both $[\mathrm{Col} / \text { sid2 }]_{\mathrm{Psm}}$ and $[\mathrm{S} / \mathrm{M}]_{\mathrm{SA}}$ values close to 1 (Figure 4).
Noticeably, the average $[P / M]_{\text {SAR }}$ ratios and the $[S / M]_{f l g 22}$ ratios were higher for the SA-dependent than for the SAindependent $\mathrm{SAR}^{+}$genes, indicating a comparable high degree of up-regulation of SA-regulated genes upon both SAR induction and flg22-treatment (Figure 2B). When examining the expression patterns of individual SA-dependent $\mathrm{SAR}^{+}$genes, it became apparent that several genes such as FRK, LHT7, or UGT73D1 are strongly flg22-responsive whereas others are not at all (Figure 3). In addition, the average induction of SA-independent $\mathrm{SAR}^{+}$ genes was higher than the induction of SA-dependent $\mathrm{SAR}^{+}$ genes in Psm-inoculated tissue, in $\mathrm{H}_{2} \mathrm{O}_{2}$-treated tissue, and in ABA-treated tissue (Figure 2B), indicating a more prominent stimulatory capacity of $\mathrm{H}_{2} \mathrm{O}_{2}$ - and ABA-signaling on the expression of individual members of the SA-independent compared with the SA-dependent gene cluster (Figures 2B, 3, 4).

\section{SAR $^{+}$GENES EXHIBITING TIGHT SA REGULATION (SAR ${ }^{+}$GENE CLUSTER I)}

Representative examples of $\mathrm{SAR}^{+}$genes tightly regulated by SA are PR1, the classical marker gene for SA-dependent defense gene activation (Nawrath and Métraux, 1999), NIMIN1, UGT76B1, WRKY38, GRXS13, NUDX6, SDR3, WRKY70, and MLO2 (Figure 3). NPR1, encoding a critical regulator of SAR that functions in SA perception and transcriptional activation of 


\begin{tabular}{|c|c|c|c|c|c|c|c|c|c|c|c|c|c|c|c|}
\hline gene locus & $\begin{array}{c}\text { gene } \\
\text { name }\end{array}$ & \begin{tabular}{|c|} 
SAR \\
{$[P / \mathrm{M}]$}
\end{tabular} & \begin{tabular}{|l} 
BTH \\
{$[\mathrm{S} / \mathrm{M}]$}
\end{tabular} & \begin{tabular}{|l|}
$P_{s m}$ \\
{$[\mathrm{~S} / \mathrm{M}]$}
\end{tabular} & \begin{tabular}{|l} 
Psm \\
{$[\mathrm{Col} /$} \\
sid2]
\end{tabular} & \begin{tabular}{|l|} 
Psm \\
{$[$ [Col/ } \\
npri1]
\end{tabular} & \begin{tabular}{|c|} 
SA \\
{$[\mathbf{S} / \mathrm{M}]$}
\end{tabular} & \begin{tabular}{|l|}
$\left.\begin{array}{c}\text { Psm } \\
{[\mathrm{Col} /} \\
\text { pad4 }]\end{array}\right]$ \\
\end{tabular} & \begin{tabular}{|l|} 
Psm \\
{$[$ Col/ } \\
ein2]
\end{tabular} & \begin{tabular}{|l|} 
Psm \\
{$[$ Col/ } \\
coiit $]$ \\
\end{tabular} & \begin{tabular}{|l|}
$\mathrm{MeJA}$ \\
{$[\mathrm{S} / \mathrm{M}]$}
\end{tabular} & \begin{tabular}{|l|}
$\mathrm{H}_{2} \mathrm{O}_{2}$ \\
{$[\mathrm{~S} / \mathrm{M}]$}
\end{tabular} & \begin{tabular}{|l} 
ABA \\
{$[S / M]$}
\end{tabular} & \begin{tabular}{|l|}
$\mathrm{flg} 22$ \\
{$[\mathrm{~S} / \mathrm{M}]$}
\end{tabular} & gene description \\
\hline At3g55970 & JRG21 & 0.4 & 0.2 & 56.0 & 1.0 & 1.1 & 0.8 & 1.1 & 1.5 & 760.4 & 32.5 & 1.6 & 0.8 & 3.9 & $\begin{array}{l}\text { JASMONATE-REGULATED GENE 21, } \\
\text { 2-oxoglutarate-Fe(II) oxygenase }\end{array}$ \\
\hline At5g05600 & - & 0.4 & 1.1 & 14.5 & 0.8 & 0.9 & 1.0 & 0.9 & 1.6 & 464.6 & 17.3 & 1.1 & 1.0 & 1.5 & 2-oxoglutarate-Fe(II) oxygenase \\
\hline At3g11480 & BSMT1 & 0.4 & 0.7 & 293.2 & 0.8 & 0.6 & 0.7 & 0.6 & 3.1 & |448.4 & 7.4 & 0.5 & 1.4 & 2.0 & $\begin{array}{l}\text { benzoic acid/salicylic acid } \\
\text { methyl transferase }\end{array}$ \\
\hline At2g39030 & NATA1 & 0.4 & 0.4 & 6.4 & 0.6 & 0.7 & 0.4 & 0.5 & 1.1 & 407.1 & 48.1 & 0.9 & 6.1 & 1.1 & ornithine $\mathrm{N}$-delta-acetyltransferase \\
\hline At1g19670 & COR1 & 0.4 & 0.3 & 0.3 & 0.6 & 0.2 & 0.9 & 0.1 & 0.5 & 303.3 & 7.6 & 1.0 & 0.8 & 0.7 & $\begin{array}{c}\text { CORONATINE-INDUCED PROTEIN } 1, \\
\text { CHLOROPHYLLASE } 1 \text { (CLH1) }\end{array}$ \\
\hline At1g17380 & $J A Z 5$ & 0.4 & 2.8 & 31.7 & 1.0 & 0.8 & 1.1 & 1.0 & 1.0 & 129.1 & 19.2 & 1.3 & 0.8 & 2.1 & JASMONATE-ZIM-DOMAIN PROTEIN 5 \\
\hline At3g28220 & - & 0.2 & 0.1 & 0.3 & 0.5 & 0.2 & 0.6 & 0.1 & 0.7 & 52.4 & 59.7 & 0.8 & 2.5 & 0.6 & TRAF-like family protein \\
\hline At1g52400 & $B G L 1$ & 0.4 & 0.3 & 0.3 & 0.6 & 0.2 & 0.9 & 0.1 & 0.5 & $\mid 46.4$ & 7.8 & 1.0 & 1.0 & 0.7 & glycosyl hydrolase family 1 protein \\
\hline At1g44350 & ILL6 & 0.4 & 0.5 & 10.2 & 0.8 & 0.7 & 1.3 & 0.7 & 1.1 & 45.8 & $\mid 10.1$ & 0.9 & 0.9 & 1.4 & $\begin{array}{l}\text { IAA-LEUCINE RESISTANT-LIKE GENE 6, } \\
\text { similar to IAA amino acid conjugate hydrolase }\end{array}$ \\
\hline At $4 \mathrm{~g} 23600$ & JR2 & 0.3 & 0.1 & 2.6 & 0.7 & 0.6 & 0.8 & 0.4 & 0.9 & 45.4 & 4.4 & 1.1 & 2.0 & 0.8 & $\begin{array}{c}\text { JASMONIC ACID RESPONSIVE 2, CORONATINE } \\
\text { INDUCED } 1 \text { (CORI3), cystine lyase } \\
\end{array}$ \\
\hline At $2 g 43530$ & - & 0.3 & 0.4 & 1.0 & 0.5 & 0.4 & 0.7 & 0.2 & 0.5 & 44.4 & 8.5 & 0.8 & 1.0 & 0.9 & defensin-like (DEFL) family protein \\
\hline At1g52000 & - & 0.2 & 0.2 & 10.2 & 0.5 & 0.2 & 0.5 & 0.1 & 0.5 & $|44.3|$ & 35.4 & 0.9 & 1.4 & 0.7 & mannose-binding lectin superfamily protein \\
\hline At3g16470 & $J R 1$ & 0.4 & 0.3 & 1.0 & 0.4 & 0.3 & 0.8 & 0.2 & 0.5 & $\mid 41.4$ & 8.1 & 0.6 & 1.3 & 0.9 & $\begin{array}{l}\text { JASMONATE RESPONSIVE 1, } \\
\text { JACALIN-RELATED LECTIN } 35 \text { (JAL35) }\end{array}$ \\
\hline At5g47240 & NUDX8 & 0.2 & 0.7 & 2.2 & 0.3 & 0.2 & 0.5 & 0.2 & 1.1 & 34.9 & 12.6 & 0.7 & 1.2 & 0.9 & NUDIX HYDROLASE HOMOLOG 8 \\
\hline At4g15440 & CYP74B2 & 0.3 & 0.4 & 2.2 & 0.9 & 0.5 & 0.4 & 0.3 & 0.8 & $|33.7|$ & 17.0 & 1.1 & 1.7 & 0.7 & $\begin{array}{c}\text { cytochrome P450, hydroperoxide lyase (non- } \\
\text { functional in ecotype Col-0) }\end{array}$ \\
\hline At1g54020 & - & 0.5 & 0.1 & 8.5 & 0.3 & 0.2 & 0.7 & 0.1 & 2.7 & $|28.6|$ & 45.0 & 1.3 & 1.0 & 0.9 & $\begin{array}{c}\text { GDSL-like lipase/acylhydrolase } \\
\text { superfamily protein }\end{array}$ \\
\hline At1g70700 & JAZ9 & 0.3 & 0.8 & 4.9 & 0.7 & 0.7 & 0.8 & 0.7 & 1.2 & 28.0 & 26.3 & 1.0 & 1.0 & 0.9 & JASMONATE-ZIM-DOMAIN PROTEIN 5 \\
\hline At5g06870 & PGIP2 & 0.4 & 0.3 & 2.4 & 0.6 & 0.6 & 1.2 & 0.6 & 0.9 & $26.2 \mid$ & $\mid 17.0$ & 1.8 & 1.0 & 0.9 & \begin{tabular}{|c|} 
POLYGALACTURONASE INHIBITING PROTEIN \\
2 \\
\end{tabular} \\
\hline At1g56650 & MYB75 & 0.2 & 0.2 & 4.1 & 0.3 & 0.3 & 0.3 & 0.2 & 1.2 & 25.0 & 5.6 & 0.8 & 4.3 & 0.5 & $\begin{array}{c}\text { MYB domain containing transcription factor, } \\
\text { regulates anthocyanin biosynthesis } \\
\end{array}$ \\
\hline At5g42650 & AOS & 0.4 & 0.5 & 1.3 & 0.6 & 0.5 & 0.8 & 0.3 & 0.8 & 18.0 & $\mid 13.5$ & 1.8 & 0.8 & 1.2 & $\begin{array}{c}\text { ALLENE OXIDE SYNTHASE, CYP74A, DELAYED } \\
\text { DEHISCENCE 2, JA biosynthesis } \\
\end{array}$ \\
\hline At2g34930 & - & 0.4 & 0.2 & 1.0 & 0.6 & 0.4 & 1.3 & 0.2 & 0.6 & $|16.1|$ & 4.5 & 2.6 & 1.3 & 0.9 & $\begin{array}{l}\text { disease resistance family protein / leucine- } \\
\text { rich repeat domain }\end{array}$ \\
\hline At3g45140 & LOX2 & 0.5 & 0.4 & 2.2 & 1.0 & 0.9 & 0.9 & 0.7 & 0.7 & 15.7 & 1.8 & 1.1 & 0.9 & 0.9 & $\begin{array}{c}\text { LIPOXYGENASE 2, } \\
\text { wound-induced JA biosynthesis } \\
\end{array}$ \\
\hline At2g43550 & - & 0.2 & 0.1 & 0.2 & 0.4 & 0.2 & 0.9 & 0.04 & 0.5 & 13.6 & 7.2 & 0.6 & 0.9 & 0.7 & defensin-like (DEFL) family protein \\
\hline At $5 g 44420$ & PDF1.2 & $0.04 \mid$ & 0.1 & 0.1 & 0.02 & 0.1 & 0.4 & 0.1 & 1.6 & 11.5 & 1.1 & 0.4 & 0.7 & 0.8 & PLANT DEFENSIN 1.2 \\
\hline At5g60890 & MYB34 & 0.3 & 0.03 & 0.4 & 0.4 & 0.2 & 0.5 & 0.1 & 0.4 & 7.4 & 6.3 & 0.4 & 2.0 & 0.6 & $\begin{array}{l}\text { MYB domain cont. transcription factor, } \\
\text { ALTERED TRYPTOPHAN REGULATION } 1\end{array}$ \\
\hline
\end{tabular}

FIGURE 6 | Values of $[\mathrm{P} / \mathrm{M}]_{\mathrm{SAR}},[\mathrm{S} / \mathrm{M}]_{\text {stimulus }}$, and $[\mathrm{Col} / \text { mutant }]_{\mathrm{Psm}}$ ratios for individual genes of the group of JA-activated SAR ${ }^{-}$genes $(\mathrm{Figure} 2 \mathrm{C})$. The legend for the heat map representation is depicted in Figure $\mathbf{2}$.

downstream genes, is only moderately up-regulated in $1^{\circ}$ and $2^{\circ}$ leaf tissue upon inoculation $\left([P / \mathrm{M}]_{\mathrm{SAR}}=2.6\right)$ and thus not assigned to the group of $\mathrm{SAR}^{+}$genes. Nevertheless, its modest local up-regulation is also SA-dependent (Figure 3).

Increased expression of $P R 1$ upon SAR induction might directly contribute to resistance execution following fungal and oomycete pathogen attack, because PR1 proteins isolated from tobacco and tomato possess in vitro antifungal activity (Niderman et al., 1995). Moreover, overexpression of $P R 1$ in tobacco increases resistance to infection by the oomycetes Peronospora tabacina and Phytophthora parasitica var. nicotianae but has no protective effect on tobacco mosaic virus or $P$. syringae infection (Linthorst et al., 1989; Alexander et al., 1993; Rayapuram et al., 2008). Other SA-dependent $\mathrm{SAR}^{+}$genes have a proven role in the activation of SA-associated defense responses that confers resistance to (hemi)biotrophic pathogens. For instance, the transcription factor WRKY70 has been recognized as a regulatory node that positively regulates SA-related plant defenses and suppresses JA-mediated responses. Overexpression of WRKY70 increases basal resistance to $P$. syringae and to the powdery mildew Erysiphe cichoracearum, and results in the constitutive expression of SAR-related genes such as PR1, PR2, and PR5. Conversely, antisense suppression of WRKY70 or insertional inactivation leads to enhanced expression of JA-responsive genes and compromises E. cichoracearum resistance (Li et al., 2004, 2006). In addition, WRKY70 acts in concert with WRKY53 and WRK46, two other $\mathrm{SAR}^{+}$genes that belong to the SA-dependent and the partial SA-dependent gene cluster, respectively (Figures 3, 5). This is reflected by the finding that wrky46/53/70 triple but not wrky70 single mutants exhibit attenuated basal resistance towards P. syringae (Hu et al., 2012). Another SA-regulated SAR component that positive regulates $P R 1$ expression and is required for full basal resistance to $P$. syringae is the short chain dehydrogenase/ reductase SDR3. The metabolic function of SDR3 has not been elucidated yet (Hwang et al., 2012). Moreover, NUDX6, a member of the Nudix (nucleoside diphosphate linked to moiety $\mathrm{X}$ ) 


\begin{tabular}{|c|c|c|c|c|c|c|c|c|c|c|c|c|c|c|c|}
\hline gene locus & $\begin{array}{l}\text { gene } \\
\text { name }\end{array}$ & \begin{tabular}{|c|} 
SAR \\
{$[P / M]$}
\end{tabular} & \begin{tabular}{|l|} 
BTH \\
{$[\mathrm{S} / \mathrm{M}]$}
\end{tabular} & $\begin{array}{l}\text { Psm } \\
{[\mathrm{S} / \mathrm{M}]}\end{array}$ & \begin{tabular}{|l|} 
Psm \\
{$[\mathrm{Col} /$} \\
sid2 $]$ \\
\end{tabular} & $\left.\begin{array}{|l|}\text { Psm } \\
{[\mathrm{Col} /} \\
n p r 1]\end{array}\right]$ & \begin{tabular}{|l} 
SA \\
{$[\mathbf{S} / \mathrm{M}]$}
\end{tabular} & \begin{tabular}{|l|} 
Psm \\
{$[\mathrm{Col} /$} \\
pad4]
\end{tabular} & \begin{tabular}{|l|} 
Psm \\
{$[\mathrm{Col} /$} \\
ein2]
\end{tabular} & $\begin{array}{l}\text { Psm } \\
{[\mathrm{Col} /} \\
\text { coi1] }\end{array}$ & $\begin{array}{l}\mathrm{Me}] \mathrm{A} \\
{[\mathrm{S} / \mathrm{M}]}\end{array}$ & \begin{tabular}{|l|}
$\mathrm{H}_{2} \mathrm{O}_{2}$ \\
{$[\mathrm{~S} / \mathrm{M}]$}
\end{tabular} & \begin{tabular}{c|} 
ABA \\
{$[\mathbf{S} / \mathrm{M}]$}
\end{tabular} & $\begin{array}{l}\mathrm{flg} 22 \\
{[\mathrm{~S} / \mathrm{M}]}\end{array}$ & gene description \\
\hline At3g46660 & UGT76E12 & 1.0 & 0.7 & 1216.7 & 0.5 & 0.6 & 2.7 & 1.1 & 4.4 & 118.9 & 5.0 & 10.2 & 8.9 & 5.2 & UDP-glucosyl transferase 76E12 \\
\hline At3g11480 & BSMT1 & 0.4 & 0.7 & 293.2 & 0.8 & 0.6 & 0.7 & 0.6 & 3.1 & 448.4 & 7.4 & 0.5 & 1.4 & 2.0 & $\begin{array}{c}\text { benzoic acid/salicylic acid methyl } \\
\text { transferase }\end{array}$ \\
\hline At5g67080 & МАРККК19 & 1.0 & 6.1 & 195.6 & 0.8 & 0.9 & 1.5 & 3.1 & 7.0 & 256.1 & 17.8 & 5.2 & 2.0 & 3.2 & $\begin{array}{l}\text { MITOGEN-ACTIVATED PROTEIN KINASE } \\
\text { KINASE KINASE } 19\end{array}$ \\
\hline At1g01480 & ACS2 & 1.1 & 0.1 & 167.2 & 1.0 & 1.2 & 1.1 & 3.3 & 0.9 & 2.4 & 0.3 & 3.0 & 2.3 & 8.1 & $\begin{array}{l}\text { 1-AMINO-CYCLOPROPANE-1-CARBOX- } \\
\text { YLATE SYNTHASE 2, ethylene biosynthesis }\end{array}$ \\
\hline At3g21500 & $D X L 1$ & 1.0 & 0.1 & 166.7 & 0.4 & 0.3 & 0.9 & 3.2 & 6.9 & 232.7 & 1.3 & 1.0 & 0.5 & 1.4 & $\begin{array}{c}\text { 1-DEOXY-D-XYLULOSE 5-PHOSPHATE } \\
\text { SYNTHASE-LIKE } 1\end{array}$ \\
\hline At1g61120 & TPS4 & 0.9 & 1.1 & 163.7 & 0.7 & 0.7 & 1.6 & 1.9 & 2.2 & 765.8 & 83.1 & 1.0 & 2.4 & 9.6 & $\begin{array}{l}\text { TERPENE SYNTHASE 04, } \\
\text { geranyllinalool synthase }\end{array}$ \\
\hline At3g01420 & $D O X 1$ & 1.1 & 0.3 & 130.1 & 1.0 & 2.7 & 1.1 & 7.6 & 5.0 & 3.2 & 1.1 & 0.8 & 7.0 & 3.4 & $\begin{array}{l}\text { ALPHA-DIOXYGENASE 1, } \\
\text { fatty acid oxygenation }\end{array}$ \\
\hline At1g30135 & JAZ8 & 0.9 & 1.6 & 84.5 & 0.5 & 0.5 & 1.3 & 0.9 & 2.9 & 77.0 & 13.0 & 0.8 & 1.5 & 3.2 & JASMONATE-ZIM-DOMAIN PROTEIN 8 \\
\hline At1g52890 & ANACO19 & 0.7 & 0.5 & 50.7 & 0.9 & 1.0 & 0.5 & 1.2 & 3.4 & 6.9 & 16.0 & 1.0 & 210.7 & 5.2 & NAC transcription factor family \\
\hline At2g27690 & CYP94C1 & 0.6 & 7.4 & 49.1 & 2.1 & 2.2 & 3.4 & 3.1 & 1.3 & 39.4 & 16.6 & 1.3 & 2.1 & 2.3 & $\begin{array}{l}\text { cytochrome P450 family protein; oxida- } \\
\text { tion of } 12-\mathrm{OH}-\mathrm{JA} \text {-Ile to } 12 \text { - } \mathrm{COOH}-\mathrm{JA}-\mathrm{Ile}\end{array}$ \\
\hline At2g34500 & CYP710A1 & 1.1 & 1.0 & 44.0 & 0.9 & 1.3 & 5.3 & 3.7 & 2.5 & 2.8 & 1.0 & 2.0 & 2.8 & 1.0 & $\begin{array}{l}\text { cytochrome P450 family protein, desatu- } \\
\text { ration of } \beta \text {-sitosterol to stigmasterol }\end{array}$ \\
\hline At3g12500 & PR3 & 1.0 & 0.1 & 38.3 & 1.5 & 0.8 & 1.5 & 6.5 & 2.9 & 3.9 & 1.4 & 0.9 & 3.1 & 0.5 & $\begin{array}{c}\text { PATHOGENESIS-RELATED GENE 3, } \\
\text { basic chitinase, CHI-B }\end{array}$ \\
\hline At1g05680 & UGT74E2 & 1.3 & 1.2 & 32.6 & 0.6 & 0.6 & 3.1 & 1.4 & 2.3 & 1.9 & 1.6 & 8.6 & 5.0 & 1.3 & $\begin{array}{l}\text { UDP-glucosyltransferase 74E2, } \\
\text { acts on indole-3-butyric acid }\end{array}$ \\
\hline At3g25180 & CYP82G1 & 0.6 & 1.0 & 27.4 & 0.4 & 0.5 & 0.9 & 3.2 & 2.3 & 342.4 & 2.1 & 1.3 & 1.3 & 8.6 & $\begin{array}{l}\text { cytochrome P450 family protein, bio- } \\
\text { synthesis of the homoterpene TMTT }\end{array}$ \\
\hline At5g59580 & UGT76E1 & 1.3 & 5.0 & 27.3 & 6.1 & 2.6 & 1.5 & 1.8 & 1.4 & 83.3 & 1.2 & 1.0 & 0.9 & 1.8 & UDP-glucosyltransferase 76E1 \\
\hline At3g 48520 & СYP94B3 & 0.8 & 0.5 & 22.9 & 0.5 & 0.5 & 1.3 & 0.6 & 2.3 & 22.6 & 0.9 & 1.0 & 6.2 & 3.1 & $\begin{array}{c}\text { cytochrome P450 family protein; } \\
\text { hydroxylation of JA-Ile to 12-OH-JA-Ile }\end{array}$ \\
\hline At4g39950 & СYРТ9B2 & 0.6 & 1.4 & 10.3 & 1.0 & 1.4 & 1.2 & 1.7 & 1.6 & 2.0 & 4.6 & 2.1 & 0.5 & 0.7 & $\begin{array}{l}\text { cytochrome P450 family protein; conver- } \\
\text { sion of Trp to indole-3-acetaldoxime }\end{array}$ \\
\hline
\end{tabular}

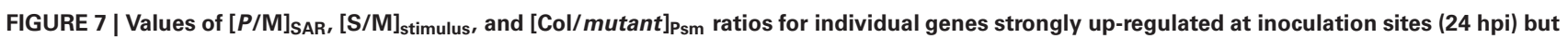
not in distal tissue (48 hpi) (Figure 2D). The legend for the heat map representation is depicted in Figure 2.

hydrolase family that catalyze the hydrolysis of several nucleoside diphosphate derivatives, not only acts in NADH metabolism in response to SA but also positively regulate SA-related defense responses (Ishikawa et al., 2010). MILDEW RESISTANCE LOCUS O 2 (MLO2) belongs to a plant-specific family of genes coding for membrane proteins that contain seven transmembrane domains. $M L O 2$ contributes to Arabidopsis resistance towards attack by the necrotrophic fungus Botrytis cinerea and participates together with other components to non-host resistance of Arabidopsis to the rice blast pathogen Magnaporthe oryzae (Humphry et al., 2010; Nakao et al., 2011). Interestingly, MLO2 has been recognized as target of the $P$. syringae type III effector HopZ2 which physically interacts with MLO2. A mlo2 insertion line exhibits increased resistance to $P$. syringae, suggesting that the MLO2/HopZ2-interaction is required for HopZ2-associated virulence (Lewis et al., 2012).

NUDX6 and GRXS13 are two examples of SA-dependent $\mathrm{SAR}^{+}$genes that appear to function in redox homeostasis during SAR. GRXS13 codes for a plant glutaredoxin which facilitates infection of Arabidopsis by B. cinerea (La Camera et al., 2011). Moreover, GRXS13 expression is critical to limit basal and photooxidative stress-induced ROS production (Laporte et al., 2012). A redox-related function might also exist for At4g39830 which encodes a putative ascorbate oxidase (Yamamoto et al., 2005). Somewhat surprisingly, several SA-regulated $\mathrm{SAR}^{+}$components obviously reduce SA accumulation and/or SA signaling and therefore appear to function in the containment of defense response activation during SAR establishment (Figure 3). For example, NIMIN-1 interacts with the SA receptor NPR1 in yeast-2-hybrid assays and functions as a negative regulator of SA-induced PR1 expression (Weigel et al., 2005). The UDP-dependent glycosyltransferase UGT76B1 can glycosylate the Ile catabolite isoleucic acid and thereby negatively influences SA accumulation (von Saint Paul et al., 2011). Beyond that, UGT76B1 exhibits in vitro glycosylating activity towards SA, and conversion of free, signaling active SA to glycosylated derivatives is supposed to attenuate SA signaling (Noutoshi et al., 2012). Finally, the transcription factor WRKY38 negatively affects SA sensitivity and basal resistance to $P$. syringae (Kim et al., 2008).

Together, SA-dependent $\mathrm{SAR}^{+}$genes can have distinct roles in the activation of defenses and resistance execution against different pathogen types (e.g. PR1, WRKY70, WRKY53, SDR3, NUDX6, MLO2), down-regulation of the JA pathway (WRKY70), redox homeostasis (GRXS13, NUDX6), and containment of defense response activation after SAR establishment (NIMIN1, UGT76B1, WRKY38) (Figure 9). The specific functions of several other $\mathrm{SA}$-regulated $\mathrm{SAR}^{+}$genes still remain to be clarified.

\section{SAR $^{+}$GENES THAT CAN BE EXPRESSED INDEPENDENTLY OF SA INCLUDE CRITICAL SAR ACTIVATORS (SAR+ GENE CLUSTER II)}

The group of SA-independent $\mathrm{SAR}^{+}$genes contains at least three genes whose functions are necessary for SAR establishment: ALD1, FMO1, and ICS1 (Figures 4, 9). ALD1 encodes a Lys 
aminotransferase (Song et al., 2004b) that mediates the biosynthesis of the Lys catabolite Pip, a critical SAR regulator (Návarová et al., 2012). Pip accumulation in $2^{\circ}$ leaves of SAR-induced plants timely precedes SA accumulation, and Pip signaling requires the flavin-dependent monooxygenase FMO1 for SAR induction. The function of Pip as a metabolic amplifier of defense signaling is crucial for the ICS1-mediated accumulation of SA in $2^{\circ}$ leaves (Mishina and Zeier, 2006; Návarová et al., 2012). Therefore, at the onset of SAR, SA-independent signaling events obviously trigger the expression of the key SAR ${ }^{+}$genes ALD1, FMO1, and ICS1 that are required for systemic SA accumulation (Figure 9). ICS1 can be regarded as a "bridge" between SA-independent and SAdependent SAR signaling events because its up-regulation results in the de novo biosynthesis of SA (Wildermuth et al., 2001). It is important to note that a feedback amplification mechanism in $2^{\circ}$ leaves that involves ALD1, Pip, FMO1, ICS1, SA, and NPR1 exists to ensure full SAR establishment (Návarová et al., 2012; Shah and Zeier, 2013). Therefore, in the context of SAR signaling and establishment in $2^{\circ}$ leaf tissue, SA-independent and SA-dependent signaling process cannot be regarded as separately acting unities. For instance, although the SA-deficient sid2 mutant is able to accumulate wild-type like Pip levels in $1^{\circ}$ leaves upon $P$. syringae inoculation, it accumulates markedly reduced Pip levels in $2^{\circ}$ leaves (Návarová et al., 2012). Thus, Pip accumulation does occur independently from the capacity of SA biosynthesis at inoculation sites, but SA synthesis is required within the abovementioned amplification cycle for the full accumulation of Pip in systemic tissue (Figure 9). Similarly, the systemic up-regulation of SA-independent genes might be substantially reduced in sid2, as has previously been shown for FMO1 (Mishina and Zeier, 2006). Thus, the classification of $\mathrm{SAR}^{+}$genes as "SA-independent" is based on expression characteristics in $1^{\circ}$ leaves (Table 6) and does not consider the necessity of SA production for SAR-associated signal amplification in $2^{\circ}$ leaves.

Another $\mathrm{SAR}^{+}$gene up-regulated at inoculation sites in an SAindependent fashion is PBS3 (alias GH3.12, GDG1, and WIN3) (Figure 4). Null mutants of pbs3 exhibit severe defects in the induction of local resistance to bacterial infection and are significantly but not fully compromised in SAR (Jagadeeswaran et al., 2007; Lee et al., 2007; Nobuta et al., 2007). PBS3 acts upstream of SA in the induction of immune responses and encodes a GH3 acyl adenylase that is able to conjugate 4-substituted benzoic acid derivatives to amino acids in vitro (Okrent et al., 2009). HSP90-1 and HSP70 are SA-independent SAR ${ }^{+}$genes strongly up-regulated by $\mathrm{H}_{2} \mathrm{O}_{2}$ (Figure 4). HSP90-1 encodes a cytosolic isoform of the heat shock protein HSP90 that associates with the co-chaperones SGT1 and RAR1 to mediate the maturation of various nucleotide-binding domain and leucine-rich repeat containing (NLR)-type of resistance proteins. Gene knockouts of RAR1, SGT1 or HSP90 compromise resistance against various bacterial, fungal and viral pathogens (Kadota and Shirasu, 2012). Arabidopsis SGT1a but not SGT1b or RAR1 falls into the category of (SA-dependent) $\mathrm{SAR}^{+}$genes (Figure 9). HSP70 (alias HSC70-4) represents one of four cytosolic HSC70 isoforms that, similarly to HSP90, interact with the co-chaperone SGT1. Knockout of individual cytosolic HSC70 genes has no defense phenotype, but HSC70-1 overexpression compromises resistance to virulent and avirulent pathogens (Noël et al., 2007).

A typical local response of Arabidopis leaves to infection with necrotrophic or (hemi)biotrophic pathogens is the accumulation of the indolic phytoalexin camalexin (Glawischnig, 2007). In Psm-inoculated plants, camalexin is heavily produced in locally infected tissue but the phytoalexin does not accumulate systemically in $2^{\circ}$ leaves (Figures $\mathbf{8 A}, \mathbf{B}$ ). However, SAR-induced plants are conditioned to more vigorously synthesize camalexin in response to subsequent pathogen encounter, and this priming effect is mediated by Pip (Návarová et al., 2012). The induction of camalexin biosynthesis at pathogen inoculation sites is associated with a modest activation of genes coding for enzymes of the Trp biosynthetic pathway and strong induction of genes encoding cytochrome P450 monooxygenases involved in Trp catabolism towards camalexin: CYP79B2/3, CYP71A13, and CYP71B15 (alias $P A D 3)$ (Ren et al., 2008). In $2^{\circ}$ leaves of SAR-induced plants, $P A D 3$ expression is strongly and CYP71A13 expression is moderately up-regulated, and both genes belong to the SA-independent cluster (Figure 4). By contrast, Psm-inoculation does only lead to a local but not a systemic up-regulation of CYP79B2 (Figure 7), and CYP79B3 is neither locally nor systemically up-regulated. This expression pattern is consistent with the observed lack of systemic camalexin accumulation because $C Y P 79 B$ expression and thus the metabolic step from Trp to indole-3-acetaldoxime (IAOx) are not activated in $2^{\circ}$ leaves of SAR-induced plants. However, enhanced systemic expression of CYP71A13 and PAD3 pre-activates the pathway downstream of IAOx. This partial biosynthetic pathway activation can explain why camalexin accumulation is primed upon SAR induction and therefore can occur faster and more pronouncedly in challenged SAR-induced than in challenged control plants: key enzymes of the pathway are already expressed before the challenge inoculation takes place, and the ab initio expression of fewer components (for camalexin biosynthesis probably merely CYP79B2) is therefore required to provide the full enzymatic capacity for the biosynthesis of the metabolite (Figure 9). The WRK33 transcription factor controls the activation of camalexin biosynthetic genes and camalexin production, and WRKY33 activity is regulated via a MAP kinase cascade involving MPK3 and MPK6 (Mao et al., 2011). WRKY33 and $M P K 3$ but not MPK6 are up-regulated during SAR in a largely SA-independent manner (Figures 4, 5).

As stated above, the average responsiveness to $\mathrm{H}_{2} \mathrm{O}_{2}, \mathrm{ABA}$, and JA/ET is higher for $\mathrm{SAR}^{+}$genes assigned to the SAindependent cluster than for those assigned to the SA-dependent cluster (Figure 2B). This is based on the fact that individual SA-independent genes are strongly inducible by $\mathrm{H}_{2} \mathrm{O}_{2}$ (e.g. CYP81D8, WRKY33, BCB, HSP70, HSP90-1, ZAT12) or ABA (e.g. CHI, SAG13, GST22, HSP70), and that some genes are modestly inducible by JA/ET signaling (e.g. AIG2, GST22, PDR12, FMO1). Moreover, PDR12 encodes an ATP-binding cassette (ABC) transporter that mediates cellular uptake of ABA (Kang et al., 2010), and ZAT12 codes for a transcription factor implicated in ROS signaling (Davletova et al., 2005). This raises the question whether an early wave of ROS-, JA/ET-, and/or ABA-signaling would precede Pip- and SA-mediated establishment of SAR in $2^{\circ}$ leaves (Figure 9). An earlier work on P. syringae-induced SAR 

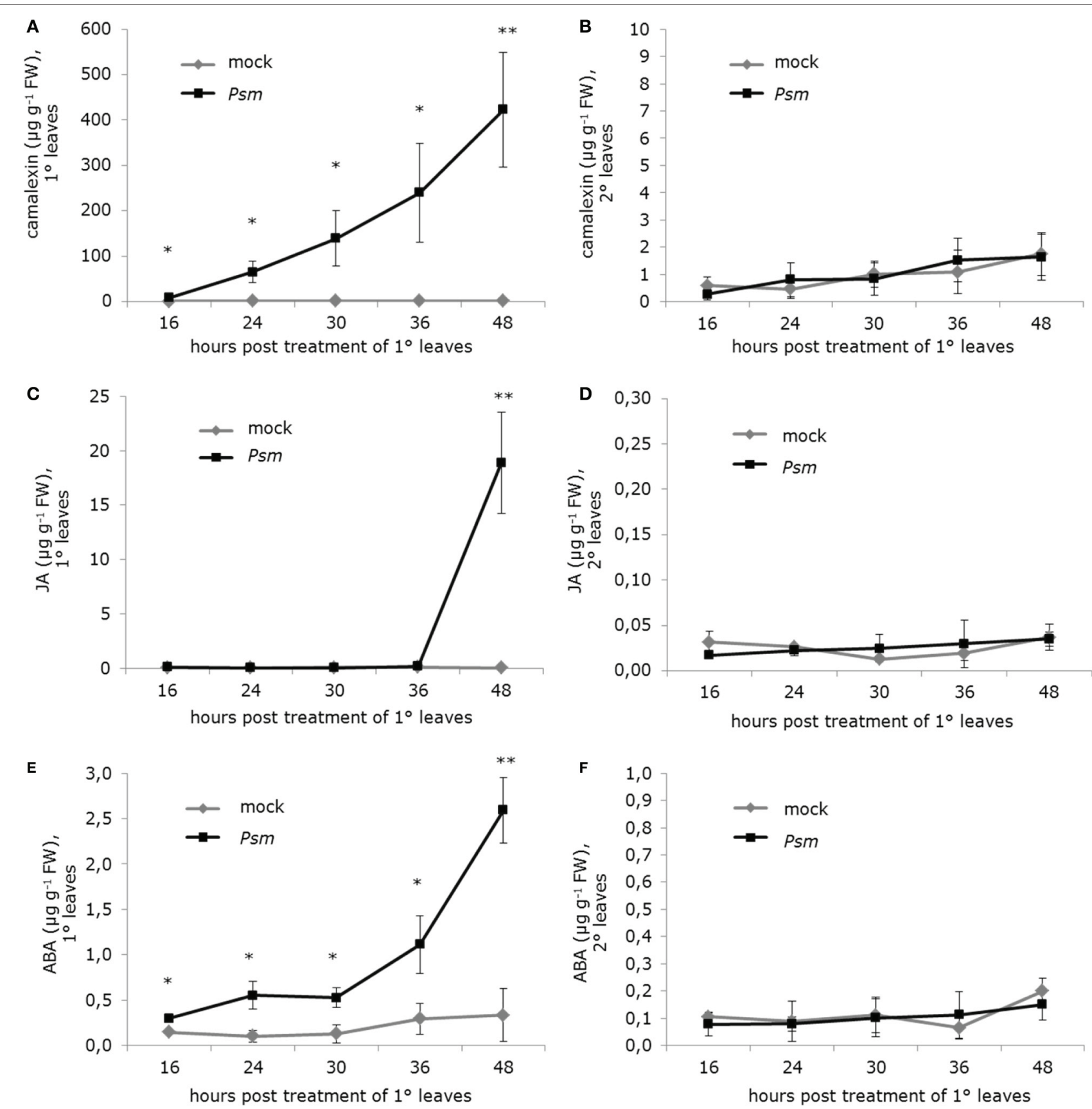

FIGURE 8 | Levels of camalexin, jasmonic acid (JA), and abscisic acid (ABA) in treated $\left(1^{\circ}\right)$ and non-treated distal $\left(2^{\circ}\right)$ leaves of Arabidopsis Col-0 plants inoculated with a suspension of $P$ syringae pv. maculicola (Psm; OD 0.005 ) or infiltrated with a $10 \mathrm{mM} \mathrm{MgCl} 2$ solution (mock-treatment). Data represent the mean \pm SD of at least three replicate samples. Asterisks denote statistically significant differences

between Psm- and mock-samples (** $P<0.01$; ${ }^{*} P<0.05$; two-tailed $t$-test). $(\mathbf{A}, \mathbf{B})$ Camalexin levels at indicated times post treatment of $1^{\circ}$ leaves in (A) $1^{\circ}$ leaves and (B) $2^{\circ}$ leaves. (C,D) JA levels at indicated times post treatment of $1^{\circ}$ leaves in (C) $1^{\circ}$ leaves and (D) $2^{\circ}$ leaves. (E) and (F) ABA levels at indicated times post treatment of $1^{\circ}$ leaves in (E) $1^{\circ}$ leaves and (F) $2^{\circ}$ leaves.

has reported the involvement of systemic ROS micro-bursts in the SAR regulatory network of $2^{\circ}$ leaf tissue that requires an early oxidative burst in $1^{\circ}$ inoculated leaves. These systemic microbursts were only observed in plants inoculated with avirulent but not with virulent P. syringae (Alvarez et al., 1998).
However, the fact that both avirulent and virulent $P$. syringae are able to induce a typical SAR response argues against a critical role of microbursts in SAR activation (Mishina and Zeier, 2006, 2007; Attaran et al., 2009; Jing et al., 2011; Liu et al., 2011). Moreover, the occurrence of systemic microbursts during SAR has not been 


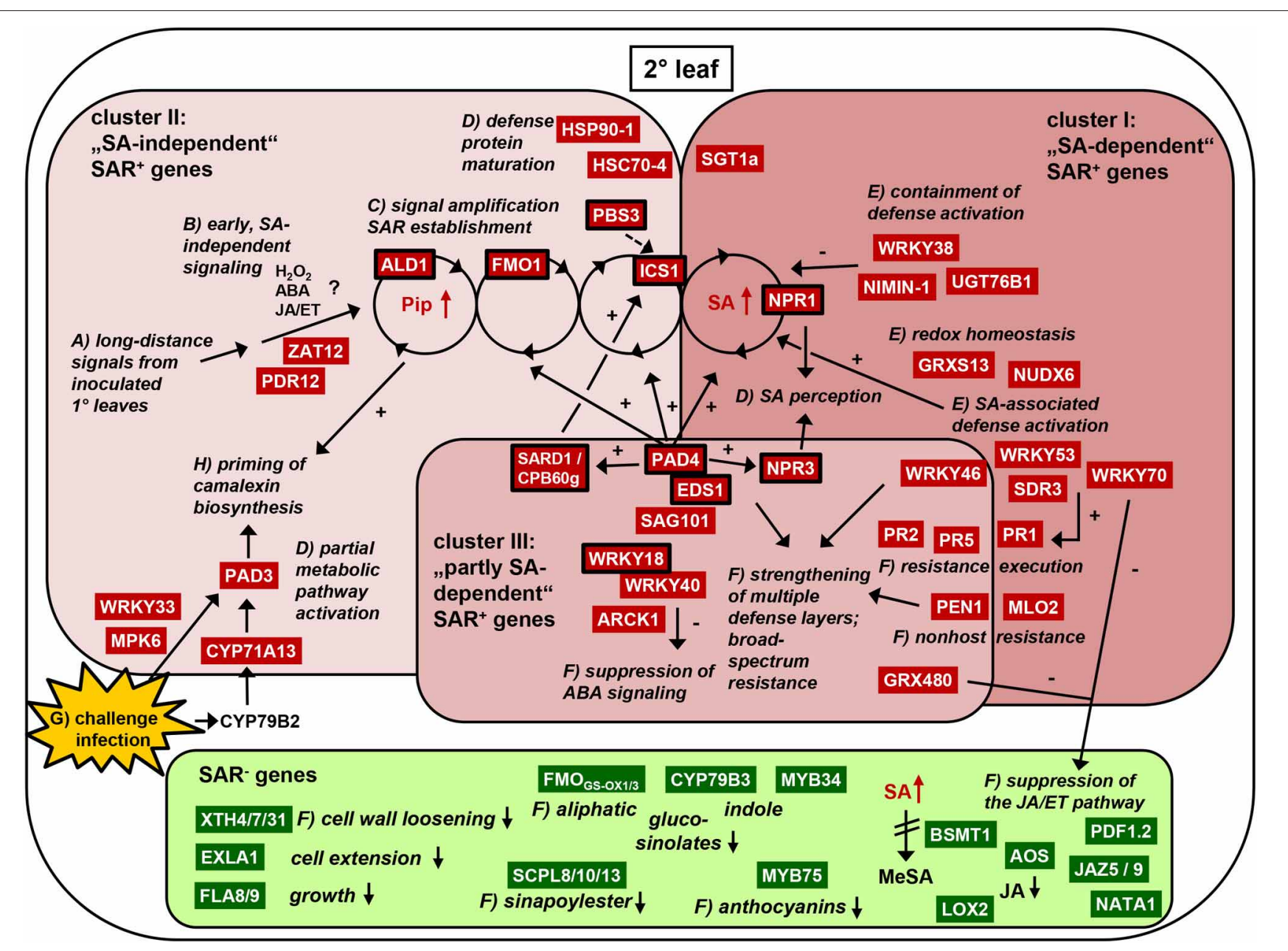

FIGURE 9 | Events occurring in distal $\left(2^{\circ}\right)$ leaves of Arabidopsis plants in which SAR has been biologically activated by Psm inoculation in $1^{\circ}$ leaves. SAR up-regulated (SAR ${ }^{+}$genes) are depicted in red, SAR down-regulated genes (SAR- genes) depicted in green. Genes known to be indispensable for SAR activation are framed with a black line. The three clusters of SA-independent, SA-dependent, and partially SA-dependent SAR ${ }^{+}$ genes are illustrated. Processes leading to SAR establishment and functions of individual SAR-related genes or groups of genes are italicized. The alphabetical labels indicate a hypothetical order of events. (A) First, long-distance signals derived from inoculated leaves activate initial SA-independent signaling events. (B) Possible contributions of ROS, ABA, or $J A / E T$ to these initial events are hypothetic or even doubtful. (C) A feedback amplification cycle (depicted as interconnected wheels) that requires the accumulation and the action of the two critical SAR metabolites pipecolic acid (Pip) and salicylic acid (SA) as well as the function of the

flavin-monooxygenase FMO1 establishes SAR. (D-F) Various events such as the activation of SA signaling, resistance induction, suppression of JA- and ABA-signaling, and partial pre-activation of camalexin biosynthesis occur. $(\mathbf{G}, \mathbf{H})$ SAR-induced plants are primed for early defense activation such as camalexin accumulation and defense gene expression. Small up arrows symbolize metabolite accumulation, small down arrows symbolize reduction of metabolite biosynthesis or of indicated physiological responses. Large arrows indicate the interconnection between the responses. Plus-signs symbolize activation, minus-sings repression. The indicated events are described in detail in the main text and summarized in the "Summary and conclusions" paragraph. confirmed by other studies. However, wounding and different abiotic stresses can trigger systemic ROS signaling that is dependent on the NADPH oxidase RBOHD (Miller et al., 2009). Miller et al., reported that the RBOHD-dependent signal can translocate from wounded to systemic tissue within minutes. This rapid systemic distribution of the ROS-related signal is not in accordance with the relatively slow establishment of SAR that essentially takes place between day 1 and day 2 after $1^{\circ}$ pathogen inoculation for the Psm-Arabidopsis interaction (Mishina et al., 2008), and it is thus not clear whether ROS signaling indeed contributes to SAR establishment.
Is the relatively high number of strongly ABA- and moderately JA/ET-responsive genes in the SA-independent group indicative for early ABA- and JA/ET-signaling events required for SAR establishment? Truman et al. (2007) have described an early JA response in $2^{\circ}$ leaves of plants inoculated with very high titers $\left[\mathrm{OD}_{600}=0.2\right]$ of avirulent $P$. syringae pv. tomato DC3000 (Pst) expressing the avrRpm1 avirulence gene (Pst avrRpm1) that was associated with an increase of JA in petiole exudates collected from $1^{\circ}$ leaves. These high initial titers of Pst avrRpml induce a rapid HR in leaves, and the necrotic disruption of leaf tissue goes hand in hand with the accumulation of JA and other 
oxylipins (Mishina and Zeier, 2007; Zoeller et al., 2012). By contrast, our experimental conditions include bacterial inoculations with lower densities $\left(\mathrm{OD}_{600}=0.005\right)$ of compatible Psm, which are not associated with an HR and elevations of JA in petiole exudates (Návarová et al., 2012). Although JA levels rise in Psm-inoculated leaves at about $48 \mathrm{hpi}$, systemic rises of JA are not detected between 16 to 48 hpi (Figures 8C,D). Considering these data and the above-mentioned 24 hpi to 48 hpi time window in which SAR establishment takes place in Psm-inoculated Arabidopsis plants, it seems unlikely that JA signaling contributes to the up-regulation of the moderately JA/ET-responsive $\mathrm{SAR}^{+}$ genes of the SA-independent gene cluster. Irrespective of the existence of an early wave of systemic JA signaling after bacterial inoculation, its influence on SAR induction is supposedly negligible, because different Arabidopsis mutants compromised in JA biosynthesis or downstream signaling are SAR-competent (Attaran et al., 2009).

The accumulation of ABA in Psm-inoculated leaves occurs more gradually and faster than the accumulation of JA (Figure 8E), and the kinetics of $\mathrm{ABA}$ production in leaves upon bacterial attack is similar for Psm- and Pst-inoculations (Figure 8E, Fan et al., 2009). Again, the accumulation of ABA, which negatively influences SA signaling and counteracts SAR (Fan et al., 2009), is confined to the site of bacterial inoculation and does not occur in $2^{\circ}$ leaf tissue (Figure 8F). This metabolic data argues against a function for $\mathrm{ABA}$ as an initial trigger for the expression of SA-independent $\mathrm{SAR}^{+}$genes in $2^{\circ}$ leaves during SAR.

\section{THE SAR ${ }^{+}$GENE CLUSTER III CONTAINS GENES EXHIBITING PARTLY SA-DEPENDENT EXPRESSION}

The third cluster of SAR up-regulated genes contains genes that are essential for the initiation of the SAR process as well (Figures 5, 9). These include PAD4, ENHANCED DISEASE SUSCEPTIBILITY 1 (EDS1), SARD1, CBP60g, and NPR3 (Mishina and Zeier, 2007; Truman et al., 2007; Zhang et al., 2010; Rietz et al., 2011; Fu et al., 2012). These genes are less tightly regulated by SA than the cluster I genes (Figure 3), because, unlike the latter, their $[\mathrm{S} / \mathrm{M}]_{\mathrm{Psm}}$ ratios are (per definition) at least 1.5-fold higher than the corresponding $\left[\mathrm{Col} /\right.$ sid $2_{\text {Psm }}$ values (Figure 5). PAD4, EDS1, and another $\mathrm{SAR}^{+}$gene product from cluster III, SAG101 (Figure 5), constitute a family of plantspecific hydrolase proteins that are critical regulatory components of plant basal resistance to (hemi)biotrophic pathogens and ETI triggered by a subset of resistance proteins (Wiermer et al., 2005). Apart from forming homodimers, EDS1 can interact with PAD4 and SAG101, and the formation of different EDS1 homo- or heteromeric complexes is associated with distinct localization patterns in the cytoplasm and/or nucleus (Feys et al., 2005). Complex formation between EDS1 and PAD4 is required for the full establishment of SAR (Rietz et al., 2011). Moreover, the EDS1-PAD4SAG101 signaling complex also plays an important function in Arabidopsis post-invasion nonhost resistance to non-adapted powdery mildew fungi (Lipka et al., 2005). The $[\mathrm{Col} / \text { pad4 }]_{\mathrm{Psm}}$ ratios illustrate that expression of the predominant fractions of $\mathrm{SAR}^{+}$genes from all three distinguished clusters is more or less tightly regulated by PAD4, indicating an important function for PAD4 in overall SAR ${ }^{+}$gene transcription (Figures 2B, 3, 4, $5,9)$. For instance, the expression of the critical SAR regulatory pathway genes ALD1, FMO1, and ICS1 are all partially dependent on PAD4 (Figure 5; Song et al., 2004a), and consequently, accumulation of the SAR regulatory metabolites Pip and SA are both positively regulated by PAD4 (Zhou et al., 1998; Návarová et al., 2012). Moreover, PAD4 tightly regulates the Psm-induced expression of two members of the plant-specific transcription factor gene family ACBP60, SAR-DEFICIENT1 (SARD1) and CALMODULIN-BINDING PROTEIN60G (CBP60g), as well as the NPR1 homologue NPR3 (Figure 5). The SARD1 and CBP60g transcription factors are partly redundant in their function and activate pathogen-induced ICS1 transcription resulting in SA accumulation (Zhang et al., 2010; Wang et al., 2011). A sard1 cbpg60g double mutant is therefore completely SAR defective (Zhang et al., 2010). NPR3 has been recently identified, besides NPR1 and NPR4, as a bona fide SA receptor (Fu et al., 2012; Wu et al., 2012). Therefore, the $\mathrm{SAR}^{+}$gene cluster III contains central elements of both SA biosynthesis and SA downstream signaling.

The $\mathrm{SAR}^{+}$gene cluster III also contains the two WRKY transcription factor genes WRKY18 and WRKY40 (Figure 5). WRKY18, WRKY40 and WRKY60 (WRKY60 is not a SAR ${ }^{+}$ gene) constitute a group of sequence-related WRKYs with complex and partly redundant roles in plant defense against different pathogen types. WRKY18 is required for biological SAR activation and mediates a subset of NPR1-mediated responses (Wang et al., 2006). Whereas overexpression of WRKY18 alone increases resistance to $P$. syringae, simultaneous overexpression of WRKY18 and WRKY40 enhances susceptibility to the same pathogen (Xu et al., 2006). WRKY18/40/60 negatively regulate ABA signaling (Shang et al., 2010), and ABA signal transduction is also attenuated by ARCK1, another cluster III $\mathrm{SAR}^{+}$gene that encodes a receptor-like cytosolic protein kinase (Tanaka et al., 2012). Since ABA signaling can interfere with the SA pathway and thus attenuate plant defenses against (hemi)biotrophic pathogens (de Torres-Zabala et al., 2007; Fan et al., 2009), an impairment of the ABA pathway might ensure a robust $\mathrm{SA}$ response during SAR (Figure 9). Another cluster III $\mathrm{SAR}^{+}$gene is GRX480 encoding for a glutaredoxin that interacts with TGA transcription factors and negatively affects JA and ET signaling. This results in the suppression of expression of typically JA/ET-regulated genes such as PDF1.2 (Ndamukong et al., 2007; Zander et al., 2012).

The group III also contains the two SAR marker genes $P R 2$ and $P R 5$ which, similar to $P R 1$, may function in the direct execution of disease resistance because their gene products exhibit antimicrobial activity. Plant $P R 2$ genes code for $\beta-1,3$-glucanases, and purified $\beta-1,3$-glucanases from pea have been shown to act synergistically with chitinases in the degradation of fungal cell walls (Mauch et al., 1988). The PR5 protein family includes the basic osmotins whose members are homologous to the sweet-tasting protein thaumatin. Osmotin and other PR5 proteins have been shown to exhibit antifungal activity in vitro and in planta. For example, overexpression of tobacco osmotin in different plant species results in increased resistance to oomycete pathogens of the genus Phytophtora (Liu et al., 1994). Moreover, SAR ${ }^{+}$ group III contains PEN1, a critical determinant of Arabidopsis pre-invasion nonhost resistance to non-adapted powdery mildew 
fungi. PEN1 codes for a plasma membrane-resident syntaxin which becomes recruited at sites of attempted fungal ingress and is implicated in a vesicle-associated resistance mechanism that prevents fungal penetration through epidermal cell walls (Collins et al., 2003; Bhat et al., 2005). The up-regulation of genes involved in non-host resistance, basal resistance to different pathogen types and ETI indicate that SAR simultaneously strengthens different defense layers that make up the plant immune system (Thordal-Christensen, 2003).

\section{A SIGNIFICANT PORTION OF THE GENES DOWN-REGULATED DURING SAR EXHIBIT STRONG JA-RESPONSIVENESS}

A remarkable feature of the $\mathrm{SAR}^{-}$genes is that their average expression is markedly activated via the JA signaling pathway (mean $[\mathrm{Col} / \text { coil }]_{\mathrm{Psm}}=5.6$; Figure $\left.2 \mathrm{~A}\right)$. Taken the $[\mathrm{Col} / \text { coil }]_{\mathrm{Psm}}$ values as a basis, we divided the $\mathrm{SAR}^{-}$genes into three categories: JA-activated genes $\left(\left[\mathrm{Col} / \mathrm{coil}_{\mathrm{Psm}}>2 ; 76\right.\right.$ genes $)$, JA-repressed genes $\left([\mathrm{Col} / \text { coil }]_{\mathrm{Psm}}<0.5 ; 190\right.$ genes $)$, and JA-independent genes ([Col/coil $]_{\mathrm{Psm}}>0.5$ and $<2 ; 404$ genes) (Figure 2C). Although quantitatively the smallest group, the JA-activated genes most strongly influenced the average $[\mathrm{Col} / \text { coil }]_{\text {Psm }}$ ratio because most genes in this group have very high $[\mathrm{Col} / \text { coil }]_{\text {Psm }}$ ratios (average $\left.[\mathrm{Col} / \text { coil }]_{\mathrm{Psm}}=43.9\right)$. Apart from a few exceptions (e.g. PDF1.2), this is associated with high $[\mathrm{S} / \mathrm{M}]_{J A}$ ratios (average $[\mathrm{S} / \mathrm{M}]_{J A}=$ 10.3) (Figures 2C, 6). Thus, both the $\left[\mathrm{Col} /\right.$ coil $_{\mathrm{Psm}}$ and the $[\mathrm{S} / \mathrm{M}]_{\mathrm{JA}}$ ratios indicate that the members of the JA-activated group of $\mathrm{SAR}^{-}$genes are highly responsive to JA signaling.

In fact, the JA-activated group of $\mathrm{SAR}^{-}$genes consist of a series of genes typically regarded as marker genes of the JA pathway (Figure 6). Among them are JASMONATEREGULATED 21 (JRG21) (Nickstadt et al., 2004), JASMONATE ZIM-DOMAIN PROTEIN 5 (JAZ5), JAZ9 (Thines et al., 2007), BENZOIC ACID/SA CARBOXYL METHYLTRANSFERASE 1 (BSMT1) (Chen et al., 2003), N-ACETYLTRANSFERASE ACTIVITY 1 (NATA1) (Adio et al., 2011), CORONATINEINDUCED PROTEIN 1 (COR1) (Benedetti et al., 1998), JASMONIC ACID RESPONSIVE 1 (JR1), JR2 (León et al., 1998), POLYGALACTURONASE INHIBITING PROTEIN 2 (PGIP2) (Schenk et al., 2003), ALLENE OXIDE SYNTHASE (AOS) (Laudert and Weiler, 1998), LIPOXYGENASE 2 (LOX2) (Bell and Mullet, 1993), and the plant defensin PDF1.2 (Ndamukong et al., 2007). This indicates that JA defense signaling is significantly reduced in the SAR-induced state. One of the key genes involved in JA biosynthesis, AOS (Laudert and Weiler, 1998), is markedly down-regulated during SAR (Figure 6), suggesting that the JA pathway could be attenuated already at the level of JA biosynthesis. However, since the experimentally determined levels of JA are similarly low in $2^{\circ}$ leaves of mock-control and Psm-inoculated plants (Figure 8D), it is more likely that signaling events downstream of JA production are negatively affected during SAR. SAR is characterized by activated SA signaling (Figure 2A), and the well-established negative cross-talk between the SA- and JA-pathways might be responsible for the attenuation of JA responses (Spoel et al., 2003). As discussed above, molecular players such as the SA-activated transcription factor WRKY70 and the glutaredoxin GRX480 could mediate the suppression of the JA pathway during SAR (Li et al., 2004, 2006; Ndamukong et al., 2007) (Figure 9). Moreover, the decreased expression of the SA methyltransferase BSMT1 that converts signaling active SA into inactive methyl salicylate (MeSA) supposedly counteracts deactivation of the SA signal (Attaran et al., 2009; Wu et al., 2012) (Figure 9). SAR is associated with a reduced biosynthesis of constitutively produced metabolites such as glucosinolates or sinapoylmalates, as illustrated by the down-regulation of MYB34, a JA-inducible transcription factor that activates indolic glucosinolate production (Figures 6, 9) and by the decreased expression of several sinapoyltransferase genes (Table 5). Another group of secondary metabolites whose biosynthesis might be negatively affected upon SAR activation are anthocyanins, because MYB75 involved in the transcriptional regulation of anthocyanin biosynthesis (Borevitz et al., 2000) also belongs to the group of SAR-repressed and JA-activated genes (Figures 6, 9). It is likely that the production of inducible metabolites that negatively interfere with resistance to (hemi)biotrophic pathogens is also repressed during SAR. For instance, the JA-inducible acetyltransferase NATA1 mediates the formation of $\mathrm{N}$ - $\delta$-acetylornithine from ornithine. Since natal knockout lines are more resistant to $P$. syringae than the wild-type, $\mathrm{N}$ - $\delta$-acetylornithine is supposed to negatively influence bacterial resistance (Adio et al., 2011). A reduced induction of NATA1 expression during SAR (Figure 6) could therefore counteract the presumed negative effect of $\mathrm{N}-\delta$ acetylornithine on bacterial resistance. This would be consistent with the finding of Adio et al. (2011) that SA pre-treatment, which renders plants in an enhanced state of pathogen resistance, inhibits induced $\mathrm{N}-\delta$-acetylornithine formation.

\section{SIMILARITIES AND DIFFERENCES OF DEFENSE ACTIVATION IN $1^{\circ}$ AND $2^{\circ}$ LEAF TISSUE UPON BACTERIAL INOCULATION}

The signaling network underlying basal resistance to local infection exhibits overlapping features to the signaling events that activate SAR because both forms of resistance share similar regulatory factors such as ICS1, SA, NPR1, PAD4, EDS1, ALD1, Pip, and FMO1. ALD1-mediated Pip production and FMO1dependent transduction of Pip signaling do occur in both $P$. syringae-inoculated and in systemic leaf tissue (Návarová et al., 2012). Pip functions as a mediator of defense amplification in plants, and this fortification of defense responses is indispensable for the activation of SAR (Návarová et al., 2012; Shah and Zeier, 2013). The Pip/FMO1-resistance pathway is also important for local resistance induction but the extent of its impact on basal resistance appears to vary with the attacking pathogen type (Song et al., 2004a; Bartsch et al., 2006; Mishina and Zeier, 2006; Návarová et al., 2012). Further, SA accumulation and downstream signaling are common processes induced in $1^{\circ}$-inoculated leaf tissue and in distant $2^{\circ}$ leaves, and the activation of the SA pathway is required for both basal resistance to (hemi)biotrophic pathogens and SAR (Wildermuth et al., 2001; Mishina and Zeier, 2006; Spoel and Dong, 2012). The existence of common immune regulatory metabolites in $1^{\circ}$ and $2^{\circ}$ leaf tissue and the fact that most $\mathrm{SAR}^{+}$ genes are also up-regulated in inoculated tissue after pathogen encounter illustrates that overlapping signaling principles and defense mechanisms exist in inoculated $1^{\circ}$ and in systemic $2^{\circ}$ leaves (Figures 2A,B, 3, 4, 5). 
Are there characteristic differences at the levels of defense metabolite production and gene activation in $1^{\circ}$ and $2^{\circ}$ leaf tissue? A first difference is of quantitative nature: Pip and SA accumulate to markedly higher levels in $1^{\circ}$ than in $2^{\circ}$ leaf tissue (Mishina et al., 2008; Návarová et al., 2012). In addition, the levels of a significant higher number of metabolites increase in $1^{\circ}$ than in $2^{\circ}$ leaf tissue after $P$. syringae inoculation (Ward et al., 2010; Griebel and Zeier, 2010; Chanda et al., 2011; Návarová et al., 2012). As shown in Figure 8, the substances that strongly accumulate in $1^{\circ}$ but not in $2^{\circ}$ leaf tissue include JA, ABA, and camalexin. In addition, when comparing the number of genes up- or down-regulated in $1^{\circ}$ and $2^{\circ}$ leaves of Psm-treated plants in different experiments, it becomes obvious that the transcriptional changes at inoculation sites are much more pronounced than those in distant tissue (Figure 2D). From the 1921 Arabidopsis genes assigned to be locally up-regulated at $24 \mathrm{~h}$ post Psm-inoculation (Figure 2D), 299 and 19 belong to the groups of $\mathrm{SAR}^{+}$and $\mathrm{SAR}^{-}$genes, respectively. This implies that the expression levels of about $15.5 \%$ of genes locally up-regulated at $24 \mathrm{hpi}$ do increase systemically after SAR establishment, but that the expression of the largest portion of locally induced genes essentially remains unchanged at the systemic level. Strikingly, the average $[\mathrm{Col} / \text { coil }]_{\text {Psm }}$ ratio in the group of locally up-regulated genes is high (6.4) compared to the same value for $2^{\circ}$ leaves (1.1) (Figure 2D), indicating that JA signaling is strongly activated in $1^{\circ}$ but not in $2^{\circ}$ leaf tissue, in which, as discussed in the previous section (Figures 2C, 6), the expression of many JA-responsive genes is even reduced. The stimulation of JA signaling in $1^{\circ}$ leaves can be triggered by the $P$. syringae phytotoxin coronatine, a structural mimic of the signaling active JA derivative JA-Ile (Geng et al., 2012), and by endogenously produced JA. In phases of the plantbacterial interaction during which endogenous JA levels remain low (e.g. until 36 hpi for the Psm-Arabidopsis inoculation experiment shown in Figure 8C), bacterial coronatine is presumably the major stimulus. For instance, Attaran et al. (2009) performed a comparative assessment of the formation of MeSA in Arabidopsis leaves induced by coronatine-producing and non-producing Pst. MeSA is generated by the BSMT1-catalysed methylation of SA, and the BSMT1 gene is strongly JA-responsive (Figure 7). Until $24 \mathrm{hpi}$, only the coronatine-producing but not the coronatinedeficient Pst strain elicited a significant formation of MeSA in inoculated plants, indicating that bacterial-derived coronatine rather than endogenous JA triggers the metabolic response in earlier phases of the interaction (Attaran et al., 2009).

The strong activation of the JA pathway in inoculated leaves and the partial suppression of JA responses in distant leaves reflect a major difference between the hormonal status of $1^{\circ}$ and $2^{\circ}$ tissue, and this difference impacts the nature of defense responses in both tissue types. JA pathway activation at inoculation sites is at least partially causative for the more pronounced metabolite accumulation in $1^{\circ}$ compared to $2^{\circ}$ leaves because JA signaling induces the expression of a series of genes involved in metabolite biosynthesis. For example, the biosynthesis of many mono-, sesqui- and diterpenoids in plants is characteristically regulated via JA signaling (Arimura et al., 2008; Attaran et al., 2008). Indeed, among the most strongly up-regulated genes in Psminoculated tissue are JA-inducible genes involved in metabolism such as the SA methyl transferase BSMT1, the terpene synthase TPS4, several cytochrome P450 monooxygenases (e.g. CYP82G1, CYP94C1, CYP94B3, CYP79B2), and UDP-dependent glycosyltransferases (UGT76E12, UGT76E1) (Figure 7). P. syringaeinoculated Arabidopsis leaves produce the $\mathrm{C}_{16}$-homoterpene (E,E)-4,8,12-trimethyl-1,3,7,11-tridecatetraene (TMTT) in a TPS4-dependent manner (Attaran et al., 2008). TPS4 catalyses the first step of TMTT biosynthesis, i.e. the conversion of the diterpene precursor geranylgeranyl diphosphate to (E,E)geranyllinalool (Herde et al., 2008). Subsequent formation of the $\mathrm{C}_{16}$-homoterpene from $(\mathrm{E}, \mathrm{E})$-geranyllinalool by an oxidative cleavage reaction catalyzed by CYP82G1 completes TMTT biosynthesis (Lee et al., 2010). The two cytochrome P450 enzymes CYP94B3 and CYP94C1 are involved in the catabolic turnover of the signaling active jasmonate JA-Ile. CYP94B3 mediates the hydroxylation of JA-Ile to 12-hydroxy-JA-Ile and thereby inactivates hormone function (Koo et al., 2011). CYP94C1 then converts 12hydroxy-JA-Ile to the corresponding 12-carboxyderivative (Heitz et al., 2012). Another strongly Psm-up-regulated gene whose expression is only moderately affected by the JA signaling pathway is 1-AMINO-CYCLOPROPANE-1-CARBOXYLATE SYNTHASE 2 (ACS2), an ACS isoform involved in ethylene biosynthesis (Tsuchisaka et al., 2009). The activation of ET biosynthesis in P. syringae-inoculated leaves is consistent with the microarray gene expression data, because ET-dependent genes are expressed more prominently in $1^{\circ}$ (mean $\left.[\mathrm{Col} / \text { ein } 2]_{\mathrm{Psm}}=1.7\right)$ than in $2^{\circ}\left(\right.$ mean $\left.[\mathrm{Col} / \text { ein } 2]_{\mathrm{Psm}}=1.1\right)$ leaves (Figures $\left.2 \mathrm{D}, 7\right)$. Examples of genes partially regulated via ET signaling are ALPHA-DIOXYGENASE 1 (DOX1), encoding a fatty acid $\alpha$ dioxygenases which converts linolenic acid and other fatty acids into their 2-hydroperoxy derivatives (Hamberg et al., 1999). Moreover, $P R 3$ encodes a basic chitinase that is up-regulated in $1^{\circ}$ inoculated but not in $2^{\circ}$ tissue and regulated by JA/ET signaling (Figure 7; Zander et al., 2010).

Another obvious difference between the transcriptional changes in $1^{\circ}$ and $2^{\circ}$ leaves following Psm inoculation is the stronger activation of ABA-responsive genes at inoculation sites compared to systemic tissue (mean $[\mathrm{S} / \mathrm{M}]_{\mathrm{ABA}}=3.3$ and 1.5 for $1^{\circ}$ and $2^{\circ}$ leaves, respectively; Figures 2D, 7), which is consistent with the observation that ABA accumulation is restricted to bacterial inoculation sites (Figure $8 \mathrm{E}$ ). The $[\mathrm{S} / \mathrm{M}]_{\mathrm{ABA}}$ values indicate that $\mathrm{ABA}$ signaling in $1^{\circ}$ leaves contributes to the induction of genes such as ANAC019, DOX1, CYP94B3, UGT74E2, and CYP710A1 (Figure 7). The transcription factor ANAC019 binds to a drought-responsive cis-element in the early responsive to dehydration stress 1 promoter, and overexpression of ANAC019 in Arabidopsis provides increased drought tolerance (Tran et al., 2004). This is one example of the fact that the local transcriptional responses following compatible $P$. syringae inoculation show large overlap with those occurring after drought or osmotic stress (de Torres-Zabala et al., 2007), presumably because strong bacterial proliferation in leaf tissue is associated with water deprivation and tissue necrosis. Activation of ABA signaling in infected tissue has also been interpreted as an active, effector-triggered virulence strategy of the pathogen, because ABA negatively interferes with SA signaling and therefore weakens one of the major pathways of plant defense to (hemi)biotrophic pathogens (de Torres-Zabala 
et al., 2007; Fan et al., 2009). Moreover, the ABA- and $\mathrm{H}_{2} \mathrm{O}_{2}$ responsive UDP-depedent glucosyltransferase UGT74E2 that is also strongly up-regulated at inoculation sites has been implicated with the modulation of water stress responses. UGT74E2 glycosylates indole-3-butyric acid and therefore affects auxin homeostasis in plants (Tognetti et al., 2010), and modulated auxin signaling can result in disturbed plant immune responses (Truman et al., 2010). The pathogen-induced CYP710A1 gene is also moderately ABA- and $\mathrm{H}_{2} \mathrm{O}_{2}$-responsive (Figure 7), and CYP710A1 mediates the desaturation of the most common phytosterol in Arabidopsis, $\beta$-sitosterol, to produce sitosterol (Morikawa et al., 2006), which strongly accumulates in $P$. syringae-inoculated leaves, integrates into cell plasma membranes, and negatively affects plant defense and resistance to bacteria (Griebel and Zeier, 2010).

\section{SUMMARY AND CONCLUSIONS}

Based on gene expression data, metabolite data, and literature information, the present study aimed to contribute to a better understanding of the characteristics of the SAR-induced state in plants. Figure 9 summarizes main events occurring in $2^{\circ}$ leaves of plants after biological SAR activation. These include:

(1) The establishment of SAR in Arabidopsis in response to a localized leaf inoculation with the bacterial pathogen Psm is associated with a major transcriptional reprogramming in distant leaf tissue. Thereby, several hundred genes that are systemically up- $\left(\mathrm{SAR}^{+}\right.$genes) and down-regulated $\left(\mathrm{SAR}^{-}\right.$ genes) can be distinguished. This extensive transcriptional reprogramming upon SAR induction is dependent on the SAR regulatory gene FMO1.

(2) Functional categorization on the basis of GO annotations indicates that the $\mathrm{SAR}^{+}$gene cluster is enriched in genes associated with stress responses, signal transduction, transport, and the cell secretory apparatus, whereas in the SAR ${ }^{-}$ gene cluster, genes associated with the chloroplast, cell wall loosening, cell extension, and the biosynthesis of constitutively formed secondary metabolites are over-represented. This suggests that, upon SAR induction, plants redirect some of their resources from vegetative growth towards defense-related processes.

(3) Alignment of the SAR expression data with publicly available microarray information has allowed us to classify the SAR-associated genes and analyse their expression characteristics. However, since the microarray data compared in our study originate from different laboratories, experimental parameters such as plant age, growth conditions, the kind of treatment or the timing of sample collection varied between experiments (Tab. 6). For instance, whereas soil grown, 4 to 5 week-old Arabidopsis plants were used for the P. syringae-, the flg22-, the SA-, and BTH-treatments, 5-7 day-old seedlings grown on MS medium were used for the JA-, ABA-, and $\mathrm{H}_{2} \mathrm{O}_{2}$-treatments. Although these experimental differences might have impact on the expression characteristics of individual genes, the predominant part of gene regulatory principles described in this work appears robust. This is exemplified by the findings that the JA- or SA-inducibility of genes was inferred from mutant analyses $\left([\mathrm{Col} / \text { coil }]_{\mathrm{Psm}}\right.$ or $\left.[\mathrm{Col} / \text { sid2 }]_{\mathrm{Psm}}\right)$ and exogenous treatment $\left([\mathrm{S} / \mathrm{M}]_{\mathrm{JA}}\right.$ or $\left.[\mathrm{S} / \mathrm{M}]_{\mathrm{SA}}\right)$ with considerable conformity (Figures 3, 6). Moreover, the stimulus-dependent regulation of the (SAR-related) genes discussed in this study proved consistent with available literature data.

(4) Based on the expression patterns of SAR-related genes in Psm-inoculated wild-type and sid2/ics1 leaves and on the responsiveness of those genes to exogenous SA, we have categorized the group of $\mathrm{SAR}^{+}$genes into clusters of SAindependent genes (cluster II), SA-dependent genes (cluster I), and partially SA-dependent genes (cluster III).

(5) Albeit not congruent, extensive similarities of the transcriptional responses of Arabidopsis plants following biological SAR induction and treatment with the synthetic resistance activator BTH do exist. The so-called "SA analogue" BTH exhibits a broader effect on SAR-related gene expression than the endogenous defense signal SA.

(6) The cluster of SA-independent $\mathrm{SAR}^{+}$genes contains the three critical SAR components ALD1, FMO1, and ICS1, which are indispensable for SAR establishment. ALD1 and FMO1 are required for the biosynthesis and downstream signaling, respectively, of the immune regulator pipecolic acid, which mediates SAR activation via signal amplification (Návarová et al., 2012). ICS1 is involved in the de novo biosynthesis of SA (Wildermuth et al., 2001) and "connects" the SA-independent and SA-dependent phases of SAR.

(7) In the initial stages of SAR establishment in $2^{\circ}$ leaves, SAindependent signaling might precede and then activate an SA-dependent phase of SAR. Since both phases are required for the full activation of SAR, "SA-independent" and "SAdependent" signaling events cannot be regarded as separately acting units but tightly co-operate to realize SAR. The average responsiveness to $\mathrm{H}_{2} \mathrm{O}_{2}, \mathrm{ABA}$, and JA/ET is higher for $\mathrm{SAR}^{+}$genes from the SA-independent than for those from the SA-dependent group. This might suggest a role of these stimuli in the early signaling stages of SAR in $2^{\circ}$ leaves. However, metabolite and mutant analyses rather argue against this possibility.

(8) On average, SA-dependent $\mathrm{SAR}^{+}$genes exhibit a higher responsiveness to flg22 than $\mathrm{SA}$-independent $\mathrm{SAR}^{+}$genes. (Partially) SA-dependent $\mathrm{SAR}^{+}$genes function in the activation or maintenance of distinct defense layers (nonhost resistance, basal resistance, ETI), and in resistance execution against different pathogen types. This indicates that SAR heightens the plant immune system on several levels and illustrates the hallmark of SAR as a state of broad-spectrum resistance. Other SA-regulated $\mathrm{SAR}^{+}$genes are involved in redox homeostasis and in the containment of defense response activation after SAR establishment.

(9) Negative cross-talk between JA/ET- or ABA-signaling pathways on the SA defense pathway is well-documented (Spoel et al., 2003; Fan et al., 2009). Several SAR ${ }^{+}$genes are involved in the suppression of ABA- and JA/ET-signaling, suggesting that they can relieve inhibitory effects of these hormonal pathways on the SA pathway during SAR. Suppression of JA signaling during SAR also manifests itself 
in the fact that many highly JA-responsive genes are among the most strongly down-regulated genes during SAR.

(10) Overlapping defense principles exist for the induction of local resistance responses and SAR. However, the transcriptional and metabolic responses at sites of bacterial inoculation are generally more pronounced than those in systemic tissue. A major difference between the $1^{\circ}$ inoculated and the $2^{\circ}$ leaves relates to the stress hormonal status: whereas SA, Pip, JA, and ABA are produced at inoculation sites to largely high levels, only Pip and SA moderately accumulate at the systemic level (Figure 8; Mishina et al., 2008; Návarová et al., 2012). Therefore, JA/ET- and ABA-triggered responses are strongly induced in $1^{\circ}$ leaves, whereas these responses are not activated or even suppressed (see above) in the $2^{\circ}$ leaves.

(11) Pip accumulation during SAR primes plants to more quickly and effectively activate defense responses to subsequent pathogen encounter. A strongly primed defense response in Arabidopsis in SAR-induced plants is the Psm-triggered accumulation of the phytoalexin camalexin (Návarová et al., 2012). SAR is associated with enhanced expression of the camalexin biosynthetic genes CYP71A13 and PAD3 but not CYP79B2, and therefore provides partial activation of camalexin production. This implicates that fewer components would have to be induced in a future pathogen challenge to activate the whole response. Partial pre-activation

\section{REFERENCES}

Adio, A. M., Casteel, C. L., De Vos, M., Kim, J. H., Joshi, V., Li, B., et al. (2011). Biosynthesis and defensive function of $\mathrm{N} \delta$-acetylornithine, a jasmonateinduced Arabidopsis metabolite. Plant Cell 23, 3303-3318. doi: $10.1105 /$ tpc. 111.088989

Alexander, D., Goodman, R. M., Gut-Rella, M., Glascock, C., Weymann, K., Friedrich, L., et al. (1993). Increased tolerance to two oomycete pathogens in transgenic tobacco expressing pathogenesisrelated protein 1a. Proc. Natl. Acad. Sci. U.S.A. 90, 7327-7331. doi: 10.1073/pnas.90.15.7327

Alonso, J. M., Hirayama, T., Roman, G., Nourizadeh, S., and Ecker, J. R. (1999). EIN2, a bifunctional transducer of ethylene and stress responses in Arabidopsis. Science 284, 2148-2152. doi: 10.1126/science.284.5423.2148

Alvarez, M. E., Pennell, R. I., Meijer, P.-J., Ishikawa, A., Dixon, R. A., and Lamb, C. (1998) Reactive oxygen intermediates mediate a systemic signal network in the establishment of plant immunity. Cell 92, 773-784. doi: 10.1016/S0092-8674 (00)81405-1

Arimura, G. I., Garms, S., Maffei, M., Bossi, S., Schulze, B., Leitner,
M., et al. (2008). Herbivoreinduced terpenoid emission in Medicago truncatula: concerted action of jasmonate, ethylene and calcium signaling. Planta 227, 453-464. doi: 10.1007/s00425007-0631-y

Attaran, E., Rostás, M., and Zeier, J. (2008). Pseudomonas syringae elicits emission of the terpenoid (E,E)-4,8,12-trimethyl1,3,7,11-tridecatetraene in Arabidopsis leaves via jasmonate signaling and expression of the Microbe Interact. 21, 1482-1497. doi: 10.1094/MPMI-21-11-1482

Attaran, E., Zeier, T. E., Griebel, T., and Zeier, J. (2009). Methyl salicylate production and jasmonate signaling are not essential for systemic acquired resistance in Arabidopsis. Plant Cell 21, 954-971. doi: 10.1105/tpc.108.063164

Bartsch, M., Gobbato, E., Bednarek, P., Debey, S., Schultze, J. L., Bautor, J., et al. (2006). Salicylic acid-independent ENHANCED DISEASE SUSCEPTIBILITY1 signaling in Arabidopsis immunity and cell death is regulated by the monoxygenase FMO1 and the nudix hydrolase NUDT7. Plant Cell 18, 1038-1051. doi: $10.1105 /$ tpc.105.039982 terpene synthase TPS4. Mol. Plant-

of defense pathways might thus be a general mechanistic principle by which SAR-induced plants manage to accelerate defense responses when challenge-infected.

(12) Varying environmental conditions can influence the magnitude and particular mechanistic aspects of the SAR response (Shah and Zeier, 2013). The quantitative differences we have observed for the transcriptional SAR responses of experiment 3 compared with the responses in experiments 1 and 2 were associated with higher overall leaf expression levels of major anthocyanin biosynthesis genes. Leaf anthocyanin accumulation is a characteristic response to unfavorable environmental conditions (Misyura et al., 2013). An important task for future SAR research will be to systematically investigate to what extent and how other environmental issues and stress parameters influence SAR establishment.

\section{ACKNOWLEDGMENTS}

We are indebted to Dong Wang, Xinnian Dong, Raka Mitra, Jane Glazebrook, Francoise Thibaud-Nissen, Hideki Goda, Shigeo Yoshida, Yukihisa Shimida, Ron Mittler, Dierk Scheel, Frederic Brunner, Lore Westphal, the NASC's International Affymetrix Service, and the ArrayExpress functional genomics database for making ATH1 microarray data publicly available. This work was supported by a grant to Jürgen Zeier from the Swiss National Science Foundation (SNF grant No. 3100A-125374).

Bell, E., and Mullet, J. E. (1993). Characterization of an Arabidopsis lipoxygenase gene responsive to methyl jasmonate and wounding. Plant Physiol. 103, 1133-1337. doi: 10.1104/pp.103.4.1133

Benedetti, C. E., Costa, C. L., Turcinelli, S. R., and Arruda, P. (1998) Differential expression of a novel gene in response to coronatine, methyl jasmonate, and wounding in the Coil mutant of Arabidopsis. Plant Physiol. 116, 1037-1042. doi 10.1104/pp.116.3.1037

Bhat, R. A., Miklis, M., Schmelzer, E., Schulze-Lefert, P., and Panstruga, R. (2005). Recruitment and interaction dynamics of plant penetration resistance components in a plasma membrane microdomain. Proc. Natl. Acad. Sci. U.S.A. 102, 3135-3140. doi: 10.1073/pnas.0500012102

Borevitz, J. O., Xia, Y., Blount, J., Dixon, R. A., and Lamb, C. (2000). Activation tagging identifies a conserved MYB regulator of phenylpropanoid biosynthesis. Plant Cell 12, 2383-2394.

Canet, J. V., Dobón, A., Roig, A. and Tornero, P. (2010). Structurefunction analysis of nprl alleles in Arabidopsis reveals a role for its paralogs in the perception of salicylic acid. Plant Cell Environ.
33, 1911-1922. doi: 10.1111/j.13653040.2010.02194.x

Celenza, J. L., Quiel, J. A., Smolen, G. A., Merrikh, H., Silvestro, A. R., Normanly, J., et al. (2005). The Arabidopsis ATR1 Myb transcription factor controls indolic glucosinolate homeostasis. Plant Physiol. 137, 253-262. doi: 10.1104/pp.104.054395

Chanda, B., Xia, Y., Mandal, M. K., Yu, K., Sekine, K.-T., Gao, Q.-M., et al. (2011). Glycerol-3-phosphate is a critical mobile inducer of systemic immunity in plants. Nat. Genet. 43, 421-427.

Chaturvedi, R., Venables, B., Petros, R. A., Nalam, V., Li, M., Wang, X., et al. (2012). An abietane diterpenoid is a potent activator of systemic acquired resistance. Plant J. 71, 161-172. doi: 10.1111/j.1365313X.2012.04981.x

Chen, F., D'Auria, J. C., Tholl, D., Ross, J. R., Gershenzon, J., Noel, J. P., et al. (2003). An Arabidopsis thaliana gene for methylsalicylate biosynthesis, identified by a biochemical genomics approach, has a role in defense. Plant J. 36, 577-588. doi: 10.1046/j.1365-313X.2003.01902.x

Collins, N. C., Thordal-Christensen, H., Lipka, V., Bau, S., Kombrink, E., Qiu, J. L., et al. (2003). SNAREprotein-mediated disease resistance 
at the plant cell wall. Nature 425, 973-977. doi: 10.1038/nature02076

Czechowski, T., Stitt, M., Altmann, T., Udvardi, M. K., and Scheible, W. R. (2005). Genome-wide identification and testing of superior reference genes for transcript normalization in Arabidopsis. Plant Physiol. 139, 5-17. doi: 10.1104/pp.105.063743

Davletova, S., Schlauch, K., Coutu, J., and Mittler, R. (2005). The zinc-finger protein Zat12 plays a central role in reactive oxygen and abiotic stress signaling in Arabidopsis. Plant Physiol. 139, 847-856. doi: 10.1104/pp.105. 068254

Delaney, T. P., Friedrich, L., and Ryals, J. A. (1995). Arabidopsis signal transduction mutant defective in chemically and biologically induced disease resistance. Proc. Natl. Acad. Sci. U.S.A. 92, 6602-6606. doi: 10.1073/pnas.92.14.6602

Dempsey, D. A., and Klessig, D. F. (2012). SOS - too many signals for systemic acquired resistance? Trends Plant Sci. 17, 538-545. doi: 10.1016/j.tplants.2012.05.011

de Torres-Zabala, M., Truman, W., Bennett, M. H., Lafforgue, G., Mansfield, J. W., Rodriguez Egea, P., et al. (2007). Pseudomonas syringae pv. tomato hijacks the Arabidopsis abscisic acid signalling pathway to cause disease. EMBO J. 26, 1434-1443. doi: 10.1038/sj.emboj.7601575

Durrant, W. E., and Dong, X. (2004). Systemic acquired resistance. Annu. Rev. Phytopathol. 42, 185-209. doi: 10.1146/annurev.phyto.42.04 0803.140421

Fan, J., Hill, L., Crooks, C., Doerner, P., and Lamb, C. (2009). Abscisic acid has a key role in modulating diverse plant-pathogen interactions. Plant Physiol. 150, 1750-1761. doi: 10.1104/pp.109.137943

Feys, B. J., Wiermer, M., Bhat, R. A., Moisan, L. J., Medina-Escobar, N., Neu, C., et al. (2005). Arabidopsis SENESCENCE-ASSOCIATED GENE101 stabilizes and signals within an ENHANCED DISEASE SUSCEPTIBILITY1 complex in plant innate immunity. Plant Cell 17, 2601-2613. doi: 10.1105/tpc.105.033910

Fraser, C. M., and Chapple, C. (2011). The phenylpropanoid pathway in Arabidopsis. Arabidopsis Book 9:e0152. doi: 10.1199/tab.0152

Fu, Z. Q., and Dong, X. (2013). Systemic acquired resistance: Turning local infection into global defense. Annu. Rev. Plant Biol. 64, 839-863. doi: 10.1146/annurevarplant-042811-105606
Fu, Z. Q., Yan, S., Saleh, A., Wang, W., Ruble, J., Oka, N., et al. (2012). NPR3 and NPR4 are receptors for the immune signal salicylic acid in plants. Nature 486, 228-232.

Garcion, C., Baltensperger, R., Fournier, T., Pasquier, J., Schnetzer, M. A., Gabriel, J. P., et al. (2006). FiRe and microarrays: a fast answer to burning questions. Trends Plant Sci. 11, 320-322. doi: 10.1016/j.tplants.2006.05.009

Geng, X., Cheng, J., Gangadharan, A., and Mackey, D. (2012). The coronatine toxin of Pseudomonas syringae is a multifunctional suppressor of Arabidopsis defense. Plant Cell 24, 4763-4774. doi: 10.1105/tpc.112.105312

Glawischnig, E. (2007). Camalexin. Phytochemistry 68, 401-406. doi: 10.1016/j.phytochem.2006.12.005

Glawischnig, E., Hansen, B. G., Olsen, C. E., and Halkier, B. A. (2004) Camalexin is synthesized from indole-3-acetaldoxime, a key branching point between primary and secondary metabolism in Arabidopsis. Proc. Natl. Acad. Sci. U.S.A. 101, 8245-8250. doi: $10.1073 /$ pnas. 0305876101

Goda, H., Sasaki, E., Akiyama, K., Maruyama-Nakashita, A. Nakabayashi, K., Li, W., et al. (2008). The AtGenExpress hormone and chemical treatment data set: experimental design, data evaluation, model data analysis and data access. Plant J. 55, 526-542. doi: 10.1111/j.1365-313X.2008.03510.x

Gomez-Gomez, L., Felix, G., and Boller, T. (1999). A single locus determines sensitivity to bacterial flagellin in Arabidopsis thaliana. Plant J. 18, 277-284. doi: 10.1046/j.1365313X.1999.00451.x

Griebel, T., and Zeier, J. (2010). A role for $\beta$-sitosterol to stigmasterol conversion in plant-pathogen interactions. Plant J. 63, 254-268. doi: 10.1111/j.1365-313X.2010.04235.x

Hamberg, M., Sanz, A., and Castresana, C. (1999). $\alpha$-Oxidation of fatty acids in higher plants. Identification of a pathogeninducible oxygenase (piox) as an $\alpha$-dioxygenase and biosynthesis of 2-hydroperoxylinolenic acid. J. Biol. Chem. 274, 24503-24513. doi: 10.1074/jbc.274.35.24503

Heitz, T., Widemann, E., Lugan, R., Miesch, L., Ullmann, P., Désaubry, L., et al. (2012). Cytochromes P450 CYP94C1 and CYP94B3 catalyze two successive oxidation steps of plant hormone Jasmonoylisoleucine for catabolic turnover. J. Biol. Chem. 287, 6296-6306. doi: 10.1074/jbc.M111.316364
Herde, M., Gartner, K., Kollner, T. G., Fode, B., Boland, W., Gershenzon, J., et al. (2008). Identification and regulation of TPS04/GES, an Arabidopsis geranyllinalool synthase catalyzing the first step in the formation of the insect-induced volatile C-16-homoterpene TMTT. Plant Cell 20, 1152-1168. doi: 10.1105/tpc.106.049478

Hu, Y., Dong, Q., and Yu, D. (2012) Arabidopsis WRKY46 coordinates with WRKY70 and WRKY53 in basal resistance against pathogen Pseudomonas syringae. Plant Sci. 185-186, 288-297. doi: 10.1016/j.plantsci.2011.12.003

Humphry, M., Bednarek, P., Kemmerling, B., Koh, S., Stein, M., Göbel, U., et al. (2010). A regulon conserved in monocot and dicot plants defines a functional module in antifungal plant immunity. Proc. Natl. Acad. Sci. U.S.A. 107, 21896-21901. doi: 10.1073/pnas.1003619107

Hwang, S. G., Lin, N. C., Hsiao, Y. Y., Kuo, C. H., Chang, P. F., Deng, W. L., et al. (2012). The Arabidopsis short-chain dehydrogenase/reductase 3, an ABSCISIC ACID DEFICIENT 2 homolog, is involved in plant defense responses but not in ABA biosynthesis. Plant Physiol. Biochem. 51, 63-73. doi: 10.1016/j.plaphy.2011.10.013

Irizarry, R. A., Bolstad, B. M., Collin, F., Cope, L. M., Hobbs, B., and Speed, T. P. (2003a). Summaries of affymetrix genechip probe level data. Nucleic Acids Res. 31:e15. doi: 10.1093/nar/gng015

Irizarry, R. A., Hobbs, B., Collin, F., Beazer-Barclay, Y. D., Antonellis, K. J., Scherf, U., et al. (2003b). Exploration, normalization, and summaries of high density oligonucleotide array probe level data. Biostatistics 4, 249-264. doi: 10.1093/biostatistics/4.2.249

Irshad, M., Canut, H., Borderies, G., Pont-Lezica, R., and Jamet, E. (2008). A new picture of cell wall protein dynamics in elongating cells of Arabidopsis thaliana: Confirmed actors and newcomers. BMC Plant Biol. 8:94. doi: 10.1186/1471-2229-8-94

Ishikawa, K., Yoshimura, K., Harada, K., Fukusaki, E., Ogawa, T., Tamoi, M., et al. (2010). AtNUDX6, an ADP-ribose/NADH pyrophosphohydrolase in Arabidopsis, positively regulates NPR1-dependent salicylic acid signaling. Plant Physiol. 152, 2000-2012. doi: 10.1104/pp.110.153569

Jagadeeswaran, G., Raina, S., Acharya, B. R., Maqbool, S. B., Mosher
S. L., Appel, H. M., et al. (2007). Arabidopsis GH3-like defense gene 1 is required for accumulation of salicylic acid, activation of defense responses and resistance to Pseudomonas syringae. Plant J. 51, 234-246. doi: 10.1111/j.1365-313X.2007.03130.x

Jing, B., Xu, S., Xu, M., Li, Y., Li, S., Ding, J., et al. (2011). Brush and spray: a high-throughput systemic acquired resistance assay suitable for large-scale genetic screening. Plant Physiol. 157, 973-980. doi: 10.1104/pp.111.182089

Jirage, D., Tootle, T. L., Reuber, T. L., Frost, L. N., Feys, B. J., Parker, J. E., et al. (1999). Arabidopsis thaliana PAD4 encodes a lipaselike gene that is important for salicylic acid signaling. Proc. Natl. Acad. Sci. U.S.A. 96, 13583-13588. doi: 10.1073/pnas.96.23.13583

Johnson, K. L., Jones, B. J., Bacic, A., and Schultz, C. J. (2003). The fasciclin-like arabinogalactan proteins of Arabidopsis. A multigene family of putative cell adhesion molecules. Plant Physiol. 133, 1911-1925. doi: 10.1104/pp.103.031237

Jones, J. D. G., and Dangl, J. L. (2006). The plant immune system. Nature 444, 323-329. doi: 10.1038 /nature05286

Jung, H. W., Tschaplinski, T. J., Wang, L., Glazebrook, J., and Greenberg, J. T. (2009). Priming in systemic plant immunity. Science 324, 89-91. doi: 10.1126/science. 1170025

Kadota, Y., and Shirasu, K. (2012). The HSP90 complex of plants. Biochim. Biophys. Acta 1823, 689-697. doi: 10.1016/j.bbamcr.2011.09.016

Kang, J., Hwang, J. U., Lee, M., Kim, Y. Y., Assmann, S. M., Martinoia, E., et al. (2010). PDR-type ABC transporter mediates cellular uptake of the phytohormone abscisic acid. Proc. Natl. Acad. Sci. U.S.A. 107, 2355-2360. doi: 10.1073/pnas.0909222107

Katagiri, F., Thilmony, R., and He, S. Y. (2002). The Arabidopsis thalianaPseudomonas syringae interaction. Arabidopsis Book 1:e0039. doi: 10.1199/tab.0039

Katsir, L., Schilmiller, A. L., Staswick, P. E., He, S. Y., and Howe, G. A. (2008). COI1 is a critical component of a receptor for jasmonate and the bacterial virulence factor coronatine. Proc. Natl. Acad. Sci. U.S.A. 105, 7100-7105. doi: 10.1073/pnas.0802332105

Kim, K.-C., Lai, Z., Fan, B., and Chen, Z. (2008). Arabidopsis WRKY38 and WRKY62 transcription factors interact with histone 
deacetylase 19 in basal defense. Plant Cell 20, 2357-2371. doi: 10.1105/tpc.107.055566

Koo, A. J. K., Thomas, F., Cooke, T. F., and Howe, G. A. (2011). Cytochrome P450 CYP94B3 mediates catabolism and inactivation of the plant hormone jasmonoylL-isoleucine. Proc. Natl. Acad. Sci. U.S.A. 108, 9298-9303. doi: 10.1073/pnas.1103542108

La Camera, S., L'Haridon, F., Astier, J., Zander, M., Abou-Mansour, E., Page, G., et al. (2011). The glutaredoxin ATGRXS13 is required to facilitate Botrytis cinerea infection of Arabidopsis thaliana plants. Plant J. 68, 507-519. doi: 10.1111/j.1365313X.2011.04706.X

Laporte, D., Olate, E., Salinas, P., Salazar, M., Jordana, X., and Holuigue, L. (2012). Glutaredoxin GRXS13 plays a key role in protection against photooxidative stress in Arabidopsis. J. Exp. Bot. 68, 507-519.

Laudert, D., and Weiler, E. W. (1998). Allene oxide synthase: a major control point in Arabidopsis thaliana octadecanoid signalling. Plant J. 15, 675-684. doi: 10.1046/j.1365313x.1998.00245.x

Lawton, K. A., Friedrich, L., Hunt, M., Weymann, K., Delaney, T., Kessmann, H., et al. (1996). Benzothiadiazole induces disease resistance in Arabidopsis by activation of the systemic acquired resistance signal transduction pathway. Plant J. 10, 71-82. doi: 10.1046/ j.1365-313X.1996.10010071.x

Lee, M. W., Lu, H., Jung, H. W., and Greenberg, J. T. (2007). A key role for the Arabidopsis WIN3 protein in disease resistance triggered by Pseudomonas syringae that secrete AvrRpt2. Mol. PlantMicrobe Interact. 20, 1192-1200. doi: 10.1094/MPMI-20-10-1192

Lee, S., Badieyan, S., Bevan, D. R., Herde, M., Gatz, C., and Tholl, D. (2010). Herbivore-induced and floral homoterpene volatiles are biosynthesized by a single P450 enzyme (CYP82G1) in Arabidopsis. Proc. Natl. Acad. Sci. U.S.A. 107, 21205-21210. doi: 10.1073/pnas.1009975107

León, J., Rojo, E., Titarenko, E., and Sánchez-Serrano, J. J. (1998). Jasmonic acid-dependent and -independent wound signal transduction pathways are differentially regulated by $\mathrm{Ca}^{2+/}$ calmodulin in Arabidopsis thaliana. Mol. Gen. Genet. 258, 412-419. doi: $10.1007 / \mathrm{s} 004380050749$

Lewis, J. D., Wan, J., Ford, R., Gong, Y., Fung, P., Nahal, H., et al. (2012). Quantitative Interactor Screening with next-generation Sequencing (QIS-Seq) identifies Arabidopsis thaliana MLO2 as a target of the Pseudomonas syringae type III effector HopZ2. BMC Genomics 13:8. doi: 10.1186/1471-2164-13-8

Li, J., Brader, G., Kariola, T., and Palva, E. T. (2006). WRKY70 modulates the selection of signaling pathways in plant defense. Plant $J$. 46, 477-491. doi: 10.1111/j.1365313X.2006.02712. $\mathrm{x}$

Li, J., Brader, G., and Palva, E. T. (2004). The WRKY70 transcription factor: a node of convergence for jasmonate-mediated and salicylate-mediated signals in plant defense. Plant Cell 16, 319-331. doi: 10.1105/tpc.016980

Li, J., Hansen, B. G., Ober, J. A., Kliebenstein, D. J., and Halkier, B. A. (2008). Subclade of flavinmonooxygenases involved in aliphatic glucosinolate biosynthesis. Plant Physiol. 148, 1721-1733. doi: 10.1104/pp.108.125757

Li, Y., Darley, C. P., Ongaro, V., Fleming, A., Schipper, O., Baldauf, S. L., et al. (2002). Plant expansins are a complex multigene family with an ancient evolutionary origin. Plant Physiol. 128, 854-864. doi: 10.1104/pp.010658

Linthorst, H. J., Meuwissen, R. L., Kauffmann, S., and Bol, J. F. (1989). Constitutive expression of pathogenesis-related proteins PR-1, GRP, and PR-S in tobacco has no effect on virus infection. Plant Cell 1, 285-291.

Lipka, V., Dittgen, J., Bednarek, P., Bhat, R., Wiermer, M., Stein, M., et al. (2005). Pre- and postinvasion defenses both contribute to nonhost resistance in Arabidopsis. Science 310, 1180-1183. doi: 10.1126/science.1119409

Liu, D., Raghothama, K. G., Hasegawa, P. M., and Bressan, R. A. (1994). Osmotin overexpression in potato delays development of disease symptoms. Proc. Natl. Acad. Sci. U.S.A. 91, 1888-1892. doi: 10.1073/pnas.91.5.1888

Liu, P. P., von Dahl, C. C., and Klessig, D. F. (2011). The extent to which methyl salicylate is required for signaling systemic acquired resistance is dependent on exposure to light after infection. Plant Physiol. 157, 2216-2226.

Livak, K. J., and Schmittgen, T. D. (2001). Analysis of relative gene expression data using real-time quantitative PCR and the $2^{-\Delta \Delta c} \mathrm{~T}$ method. Methods 25, 402-408. doi: 10.1006/meth.2001.1262

Maldonado, A. M., Doerner, P., Dixon, R. A., Lamb, C. J., and Cameron,
R. K. (2002). A putative lipid transfer protein involved in systemic acquired resistance signalling in Arabidopsis. Nature 419, 399-403. doi: 10.1038/nature00962

Maleck, K., Levine, A., Eulgem, T., Morgan, A., Schmid, J., Lawton, K. A., et al. (2000). The tran scriptome of Arabidopsis thaliana during systemic acquired resistance. Nat. Genet. 26, 403-410. doi: $10.1038 / 82521$

Mao, G., Meng, X., Liu, Y., Zheng, Z., Chen, Z., and Zhang, S (2011). Phosphorylation of a WRKY transcription factor by two pathogen-responsive MAPKs drives phytoalexin biosynthesis in Arabidopsis. Plant Cell 23, 1639-1653. doi: 10.1105/tpc.111.084996

Mauch, F., Mauch-Mani, B., and Boller, T. (1988). Antifungal hydrolases in pea tissue: II. Inhibition of fungal growth by combinations of chitinase and $\beta$-1,3-glucanase. Plant Physiol. 88, 936-942. doi: 10.1104/pp.88.3.936

Métraux, J.-P. (2002). Recent breakthroughs in the study of salicylic acid biosynthesis. Trends Plant Sci. 7, 332-334. doi: 10.1016/S13601385(02)02313-0

Métraux, J.-P., Signer, H., Ryals, J., Ward, E., Wyss-Benz, M., Gaudin, J., et al. (1990). Increase in salicylic acid at the onset of systemic acquired resistance in cucumber. Science 250, 1004-1006. doi 10.1126/science. 250.4983 .1004

Miller, G., Schlauch, K., Tam, R., Cortes, D., Torres, M. A., Shulaev, V., et al. (2009). The plant NADPH oxidase RBOHD mediates rapid systemic signaling in response to diverse stimuli. Sci. Signal. 2, ra45. doi: 10.1126/scisignal.2000448

Mishina, T. E., Griebel, T., Geuecke, M., Attaran, E., and Zeier, J. (2008) "New insights into the molecular events underlying systemic acquired resistance," in Biology of PlantMicrobe Interactions Vol. 6, eds. M. Lorito, S. L. Woo, and F. Scala (St. Paul, MN: International Society for Molecular Plant-Microbe Interactions), 81.

Mishina, T. E., and Zeier, J. (2006). The Arabidopsis flavin-dependent monooxygenase FMO1 is an essential component of biologically induced systemic acquired resistance. Plant Physiol. 141, 1666-1675. doi: 10.1104/pp.106.081257

Mishina, T. E., and Zeier, J. (2007). Pathogen-associated molecular pattern recognition rather than development of tissue necrosis contributes to bacterial induction of systemic acquired resistance in Arabidopsis. Plant J. 50, 500-513. doi: 10.1111/j.1365-313X.2007.03067.x

Misyura, M., Colasanti, J., and Rothstein, S. J. (2013). Physiological and genetic analysis of Arabidopsis thaliana anthocyanin biosynthesis mutants under chronic adverse environmental conditions. J. Exp. Bot. 64, 229-240. doi: $10.1093 / \mathrm{jxb} / \mathrm{ers} 328$

Morikawa, T., Mizutani, M., Aoki, N., Watanabe, B., Saga, H., Saito, S., et al. (2006). Cytochrome P450 CYP710A encodes the sterol C22 desaturase in Arabidopsis and tomato. Plant Cell 18, 1008-1022. doi: $10.1105 /$ tpc.105.036012

Nakao, M., Nakamura, R., Kita, K., Inukai, R., and Ishikawa, A. (2011). Non-host resistance to penetration and hyphal growth of Magnaporthe oryzae in Arabidopsis. Sci. Rep. 1, 171. doi: 10.1038/srep00171

Návarová, H., Bernsdorff, F., Döring, A.-C., and Zeier, J. (2012). Pipecolic acid, an endogenous mediator of defense amplification and priming, is a critical regulator of inducible plant immunity. Plant Cell 24, 5123-5141. doi 10.1105/tpc.112.103564

Nawrath, C., and Métraux, J.-P. (1999). Salicylic acid inductiondeficient mutants of Arabidopsis express PR-2 and PR-5 and accumulate high levels of camalexin after pathogen inoculation. Plant Cell 11, 1393-1404. doi: 10.1111/j.1365-313X.2007.03039.x

Ndamukong, I., Abdallat, A. A., Thurow, C., Fode, B., Zander M., Weigel, R., et al. (2007). SAinducible Arabidopsis glutaredoxin interacts with TGA factors and suppresses JA-responsive PDF1.2 transcription. Plant J. 50, 128-139.

Neal, C. S., Fredericks, D. P., Griffiths, C. A., and Neale, A. D. (2010). The characterisation of AOP2: a gene associated with the biosynthesis of aliphatic alkenyl glucosinolates in Arabidopsis thaliana. BMC Plant Biol. 10:170. doi: 10.1186/14712229-10-170

Nickstadt, A., Thomma, B. P. H. J., Feussner, I., Kangasjärvi, J., Zeier, J., Loeffler, C., et al. (2004). The jasmonate-insensitive mutant jin1 shows increased resistance to biotrophic as well as necrotrophic pathogens. Mol. Plant Pathol. 5, 425-434. doi: 10.1111/j.1364-3703.2004.00242.x

Niderman, T., Genetet, I., Bruyère, T., Gees, R., Stintzi, A., Legrand, M. et al. (1995). Pathogenesis-related 
PR-1 proteins are antifungal. Isolation and characterization of three 14-kilodalton proteins of tomato and of a basic PR-1 of tobacco with inhibitory activity against Phytophthora infestans. Plant Physiol. 108, 17-27. doi: 10.1104/pp.108.1.17

Nobuta, K., Okrent, R. A., Stoutemyer, M., Rodibaugh, N., Kempema, L., Wildermuth, M. C., et al. (2007). The GH3 acyl adenylase family member PBS3 regulates salicylic acid-dependent defense responses in Arabidopsis. Plant Physiol. 144, 1144-1156. doi: 10.1104/pp.107.097691

Noël, L. D., Cagna, G., Stuttmann, J., Wirthmüller, L., Betsuyaku, S., Witte, C. P., et al. (2007). Interaction between SGT1 and cytosolic/nuclear HSC70 chaperones regulates Arabidopsis immune responses. Plant Cell 19, 4061-4076. doi: 10.1105/tpc.107.051896

Noutoshi, Y., Okazaki, M., Kida, T., Nishina, Y., Morishita, Y., Ogawa, T., et al. (2012). Novel plant immune-priming compounds identified via high-throughput chemical screening target salicylic acid glucosyltransferases in Arabidopsis. Plant Cell 24, 3795-3804. doi: 10.1105/tpc.112.098343

Okrent, R. A., Brooks, M. D., and Wildermuth, M. C. (2009). Arabidopsis GH3.12 (PBS3) conjugates amino acids to 4-substituted benzoates and is inhibited by salicylate. J. Biol. Chem. 284, 9742-9754. doi: 10.1074/jbc.M806662200

Park, S.-W., Kaimoyo, E., Kumar, D., Mosher, S., and Klessig, D. F. (2007). Methyl salicylate is a critical mobile signal for plant systemic acquired resistance. Science 318, 113-116. doi: 10.1126/science. 1147113

Rayapuram, C., Wu, J., Haas, C., and Baldwin, I. T. (2008). PR-13/Thionin but not $P R-1$ mediates bacterial resistance in Nicotiana attenuata in nature, and neither influences herbivore resistance. Mol. PlantMicrobe Interact. 21, 988-1000. doi: 10.1094/MPMI-21-7-0988

Redman, J. C., Haas, B. J., Tanimoto, G., and Town, C. D. (2004). Development and evaluation of an Arabidopsis whole genome Affymetrix probe array. Plant J. 38, 545-561. doi: 10.1111/j.1365-313X.2004.02061.x

Ren, D., Liu, Y., Yang, K.-Y., Han, L., Mao, G., Glazebrook, J., et al. (2008). A fungal-responsive MAPK cascade regulates phytoalexin biosynthesis in Arabidopsis. Proc. Natl. Acad.
Sci. U.S.A. 105, 5638-5643. doi: 10.1073/pnas.0711301105

Rietz, S., Stamm, A., Malonek, S., Wagner, S., Becker, D., MedinaEscobar, N., et al. (2011). Different roles of Enhanced Disease Susceptibilityl (EDS1) bound to and dissociated from Phytoalexin Deficient4 (PAD4) in Arabidopsis immunity. New Phytol. 191, 107-119. doi: 10.1111/j.1469-8137.2011.03675.x

Rose, J. K., Braam, J., Fry, S. C., and Nishitani, K. (2002). The XTH family of enzymes involved in xyloglucan endotransglucosylation and endohydrolysis: Current perspectives and a new unifying nomenclature. Plant Cell Physiol. 43, 1421-1435. doi: $10.1093 / \mathrm{pcp} / \mathrm{pcf} 171$

Saito, K., Yonekura-Sakakibara, K., Nakabayashi, R., Higashi, Y., Yamazaki, M., Tohge, T., et al. (2013). The flavonoid biosynthetic pathway in Arabidopsis: Structural and genetic diversity. Plant Physiol. Biochem. doi: 10.1016/j.plaphy. 2013.02.001. [Epub ahead of print].

Saijo, Y., Tintor, N., Lu, X., Rauf, P., Pajerowska-Mukhtar, K., Häweker, H., et al. (2009). Receptor quality control in the endoplasmic reticulum for plant innate immunity. EMBO J. 28, 3439-3449. doi: 10.1038/emboj.2009.263

Schenk, P. M., Kazan, K., Manners, J. M., Anderson, J. P., Simpson, R. S., Wilson, I. W., et al. (2003). Systemic gene expression in Arabidopsis during an incompatible interaction with Alternaria brassicicola. Plant Physiol. 132, 999-1010. doi: 10.1104/pp.103.021683

Schultz, C. J., Rumsewicz, M. P., Johnson, K. L., Jones, B. J., Gaspar, Y. M., and Bacic, A. (2002). Using genomic resources to guide research directions. The arabinogalactan protein gene family as a test case. Plant Physiol. 129, 1448-1463. doi: 10.1104/pp.003459

Shah, J., and Zeier, J. (2013). Longdistance communication and signal amplification in systemic acquired resistance. Front. Plant Sci. 4:30. doi: 10.3389/fpls.2013.00030

Shang, Y., Yan, L., Liu, Z. Q., Cao, Z., Mei, C., Xin, Q., et al. (2010). The Mg-chelatase $\mathrm{H}$ subunit of Arabidopsis antagonizes a group of WRKY transcription repressors to relieve ABAresponsive genes of inhibition. Plant Cell 22, 1909-1935. doi: 10.1105/tpc.110.073874

Shulaev, V., Leon, J., and Raskin, I. (1995). Is salicylic acid a translocated signal of systemic acquired resistance in tobacco? Plant Cell 7 , 1691-1701.

Sønderby, I. E., Geu-Flores, F., and Halkier, B. A. (2010) Biosynthesis of glucosinolates - gene discovery and beyond. Trends Plant Sci. 15, 283-290. doi: 10.1016/j.tplants.2010.02.005

Song, J., Lu, H., McDowell, J. M., and Greenberg, J. (2004a). A key role for $A L D 1$ in activation of local and systemic defenses in Arabidopsis. Plant J. 40, 200-212. doi: 10.1111/j.1365313X.2004.02200.x

Song, J., Lu, H., and Greenberg, J. (2004b). Divergent roles in Arabidopsis thaliana development and defense of two homologous genes, ABERRANT GROWTH AND DEATH2 and AGD2-LIKE DEFENSE RESPONSE PROTEIN1, encoding novel aminotransferases. Plant Cell 16, 353-366. doi: 10.1105/tpc.019372

Spoel, S. H., and Dong, X. (2012). How do plants achieve immunity? Defence without specialized immune cells. Nat. Rev. Immunol. 12, 89-100. doi: 10.1038/nri3141

Spoel, S. H., Koornneef, A., Claessens, S. M., Korzelius, J. P., Van Pelt, J. A., Mueller, M. J., et al. (2003). NPR1 modulates cross-talk between salicylate- and jasmonatedependent defense pathways through a novel function in the cytosol. Plant Cell 15, 760-770. doi: 10.1105/tpc.009159

Stehle, F., Brandt, W., Stubbs, M. T., Milkowski, C., and Strack, D. (2009). Sinapoyltransferases in the light of molecular evolution. Phytochemistry 70, 1652-1662. doi: 10.1016/j.phytochem.2009.07.023

Sticher, L., Mauch-Mani, B., and Métraux, J. P. (1997). Systemic acquired resistance. Annu. Rev. Phytopathol. 35, 235-270.

Tanaka, H., Osakabe, Y., Katsura, S., Mizuno, S., Maruyama, K., Kusakabe, K., et al. (2012). Abiotic stress-inducible receptorlike kinases negatively control ABA signaling in Arabidopsis. Plant J. 70, 599-613. doi: 10.1111/j.1365-313X.2012.04901.x

Thibaud-Nissen, F., Wu, H., Richmond, T., Redman, J. C., Johnson, C., Green, R., et al. (2006). Development of Arabidopsis wholegenome microarrays and their application to the discovery of binding sites for the TGA2 transcription factor in salicylic acid-treated plants. Plant J. 47, 152-162. doi: 10.1111/j.1365-313X.2006.02770.x

Thilmony, R., Underwood, W., and He, S. Y. (2006). Genomewide transcriptional analysis of the Arabidopsis thaliana interaction with the plant pathogen Pseudomonas syringae pv. tomato DC3000 and the human pathogen Escherichia coli O157:H7. Plant J. 46, 34-53. doi: 10.1111/j.1365-313X.2006.02725.X

Thines, B., Katsir, L., Melotto, M., Niu, Y., Mandaokar, A., Liu, G., et al. (2007). JAZ repressor proteins are targets of the SCFCOI complex during jasmonate signalling. Nature 448, 661-665. doi: 10.1038 /nature05960

Thordal-Christensen, H. (2003). Fresh insights into processes of nonhost resistance. Curr. Opin. Plant Biol. 6, 351-357. doi: 10.1016/S13695266(03)00063-3

Tognetti, V. B., Van Aken, O., Morreel, K., Vandenbroucke, K., van de Cotte, B., De Clercq, I., et al. (2010). Perturbation of indole-3butyric acid homeostasis by the UDP-glucosyltransferase UGT74E2 modulates Arabidopsis architecture and water stress tolerance. Plant Cell 22, 2660-2679. doi: 10.1105/tpc.109.071316

Tran, L. S., Nakashima, K., Sakuma, Y., Simpson, S. D., Fujita, Y., Maruyama, K., et al. (2004). Isolation and functional analysis of Arabidopsis stress-inducible NAC transcription factors that bind to a drought-responsive cis-element in the early responsive to dehydration stress 1 promoter. Plant Cell 16, 2481-2498. doi: $10.1105 /$ tpc. 104.022699

Truman, W., Bennett, M. H., Kubigsteltig, I., Turnbull, C. and Grant, M. (2007). Arabidopsis systemic immunity uses conserved defense signaling pathways and is mediated by jasmonates. Proc. Natl. Acad. Sci. U.S.A. 104, 1075-1080. doi: 10.1073/pnas.0605423104

Truman, W., de Torres-Zabala, M., and Grant, M. (2006). Type III effectors orchestrate a complex interplay between transcriptional networks to modify basal defence responses during pathogenesis and resistance. Plant J. 46, 14-33. doi: 10.1111/j.1365-313X.2006.02672.x

Truman, W. M., Bennett, M. H., Turnbull, C. G., and Grant, M. R. (2010). Arabidopsis auxin mutants are compromised in systemic acquired resistance and exhibit aberrant accumulation of various indolic compounds. Plant Physiol. 152, 1562-1573. doi: 10.1104/pp.109.152173

Tsuchisaka, A., Yu, G., Jin, H., Alonso, J. M., Ecker, J. R., Zhang, X., et al. (2009). A combinatorial interplay among the 
1-aminocyclopropane-1-carboxylate isoforms regulates ethylene biosynthesis in Arabidopsis thaliana. Genetics 183, 979-1003. doi: 10.1534/genetics.109.107102

Tsuda, K., Sato, M., Stoddard, T., Glazebrook, J., and Katagiri, F. (2009). Network properties of robust immunity in plants. PLoS Genet. 5:e1000772. doi: 10.1371/journal.pgen.1000772

von Saint Paul, V., Zhang, W., Kanawati, B., Geist, B., FausKeßler, T., Schmitt-Kopplin, P., et al. (2011). The Arabidopsis glucosyltransferase UGT76B1 conjugates isoleucic acid and modulates plant defense and senescence. Plant Cell 23, 4124-4145. doi: 10.1105/tpc.111.088443

Ward, J. L., Forcat, S., Beckmann, M., Bennett, M., Miller, S. J., Baker, J. M., et al. (2010). The metabolic transition during disease following infection of Arabidopsis thaliana by Pseudomonas syringae pv. tomato. Plant J. 63, 443-457. doi: 10.1111/j.1365-313X.2010.04254.x

Wang, D., Amornsiripanitch, N., and Dong, X. (2006). A genomic approach to identify regulatory nodes in the transcriptional network of systemic acquired resistance in plants. PLoS Pathog. 2:e123. doi: 10.1371/journal.ppat.0020123

Wang, L., Mitra, R. M., Hasselmann, K. D., Sato, M., Lenarz-Wyatt, L., Cohen, J. D., et al. (2008). The genetic network controlling the Arabidopsis transcriptional response to Pseudomonas syringae pv. maculicola: roles of major regulators and the phytotoxin coronatine. Mol. Plant-Microbe Interact. 21, 1408-1420. doi: 10.1094/MPMI-21-11-1408

Wang, L., Tsuda, K., Truman, W., Sato, M., Nguyen, L. V., Katagiri, F., et al. (2011). CBP60g and SARD1 play partially redundant critical roles in salicylic acid signaling. Plant J. 67, 1029-1041. doi: 10.1111/j.1365313X.2011.04655.x

Weigel, R. R., Pfitzner, U. M., and Gatz, C. (2005). Interaction of NIMIN1 with NPR1 modulates $P R$ gene expression in Arabidopsis. Plant Cell 17, 1279-1291. doi: 10.1105/tpc.104.027441

Wiermer, M., Feys, B. J., and Parker, J. E. (2005), Plant immunity: the EDS1 regulatory node. Curr. Opin. Plant Biol. 8, 383-389. doi: 10.1016/j.pbi.2005.05.010

Wildermuth, M. C., Dewdney, J., Wu, G., and Ausubel, F. M. (2001). Isochorismate synthase is required to synthesize salicylic acid for plant defence. Nature 414, 562-565. doi: 10.1038/35107108

Wu, Y., Zhang, D., Chu, J. Y., Boyle, P., Wang, Y., Brindle, I. D., et al. (2012). The Arabidopsis NPR1 protein is a receptor for the plant defense hormone salicylic acid. Cell Rep. 1, 639-647. doi: 10.1016/j.celrep.2012.05.008

Xu, X., Chen, C., Fan, B., and Chen, Z. (2006). Physical and functional interactions between pathogen-induced Arabidopsis WRKY18, WRKY40, and
WRKY60 transcription factors. Plant Cell 18, 1310-1326. doi: $10.1105 /$ tpc. 105.037523

Yamamoto, A., Bhuiyan, M. N. Waditee, R., Tanaka, Y., Esaka, M. Oba, K., et al. (2005). Suppressed expression of the apoplastic ascorbate oxidase gene increases salt tolerance in tobacco and Arabidopsis plants. J. Exp. Bot. 56, 1785-1796. doi: $10.1093 / \mathrm{jxb} /$ eri167

Zander, M., Chen, S., Imkampe, J., Thurow, C., and Gatz, C. (2012). Repression of the Arabidopsis thaliana jasmonic acid/ethyleneinduced defense pathway by TGA-interacting glutaredoxins depends on their C-terminal ALWL motif. Mol. Plant 5, 831-840. doi $10.1093 / \mathrm{mp} / \mathrm{ssr} 113$

Zander, M., La Camera, S., Lamotte O., Métraux, J.-P., and Gatz, C. (2010). Arabidopsis thaliana class-II TGA transcription factors are essential activators of jasmonic acid/ethylene-induced defense responses. Plant J. 61, 200-210. doi: 10.1111/j.1365-313X.2009.04044.xc

Zhang, Y., Xu, S., Ding, P., Wang, D., Cheng, Y. T., He, J., et al (2010). Control of salicylic acid synthesis and systemic acquired resistance by two members of a plant-specific family of transcription factors. Proc. Natl Acad. Sci. U.S.A. 107, 18220-18225. doi: 10.1073/pnas.1005225107

Zhou, N., Tootle, T. L., Tsui, F., Klessig, D. F., and Glazebrook, J. (1998) PAD4 functions upstream from salicylic acid to control defence responses in Arabidopsis. Plant Cell 10, 1021-1030.

Zoeller, M., Stingl, N., Krischke, M., Fekete, A., Waller, F., Berger, S., et al. (2012). Lipid profiling of the Arabidopsis hypersensitive response reveals specific lipid peroxidation and fragmentation processes: biogenesis of pimelic and azelaic acid. Plant Physiol. 160, 365-378. doi: 10.1104/pp.112.202846

Conflict of Interest Statement: The authors declare that the research was conducted in the absence of any commercial or financial relationships that could be construed as a potential conflict of interest.

Received: 28 March 2013; accepted: 21 June 2013; published online: 15 July 2013.

Citation: Gruner K, Griebel T, Návarová H, Attaran E and Zeier J (2013) Reprogramming of plants during systemic acquired resistance. Front. Plant Sci. 4:252. doi: 10.3389/fpls.2013.00252 This article was submitted to Frontiers in Plant-Microbe Interaction, a specialty of Frontiers in Plant Science.

Copyright (c) 2013 Gruner, Griebel, Návarová, Attaran and Zeier. This is an open-access article distributed under the terms of the Creative Commons Attribution License, which permits use, distribution and reproduction in other forums, provided the original authors and source are credited and subject to any copyright notices concerning any thirdparty graphics etc. 